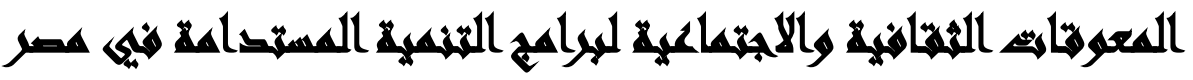

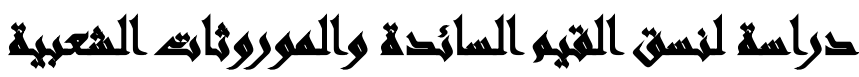

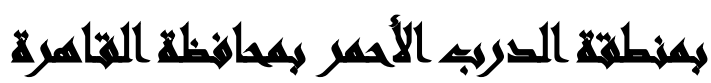

نجلاء حسن حسن الخولى (')- سهير عادل العطار (ץ)- نجوى عبد المنعم الثايب(ץ) (r)

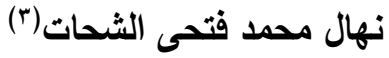

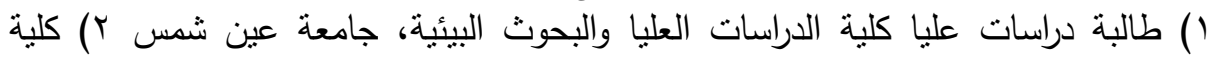
البنات للآداب والعلوم التربوية، جامعة عين شمس بات كلية الدراسات العليا والبحوث البيئية،

جامعة عين شمس لود

\section{المستصلص}

تستهدف الدراسة الحالية تحديد برامج التتمية المستدامة التى تقدمها الجمعيات الأهلية

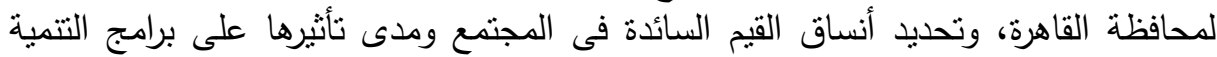

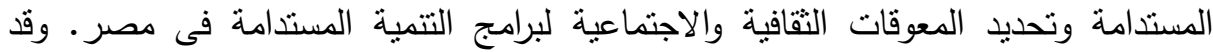

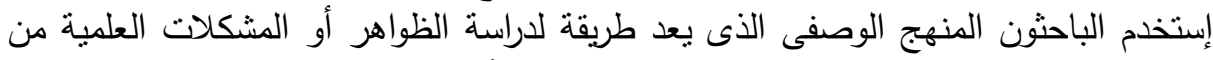

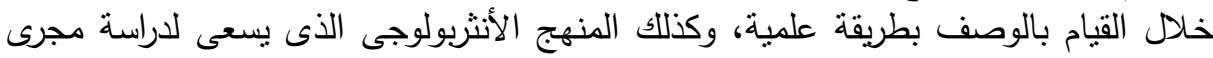

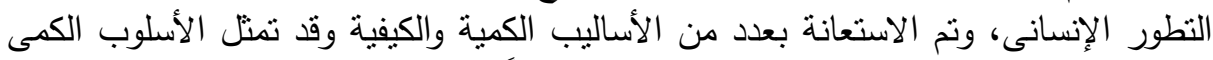

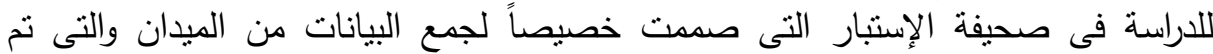

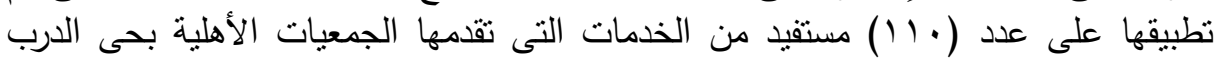

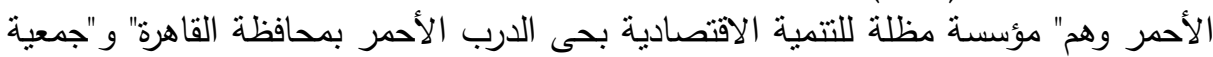

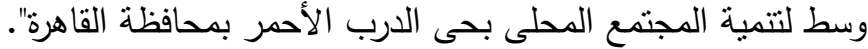

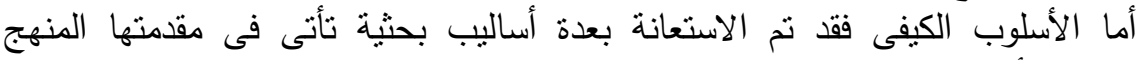

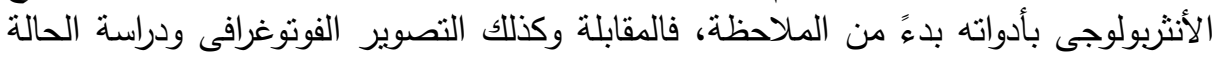
للمجتمع المحلى ودليل مقابلة للعاملين بالجمعيات الأهلية. توصلت نتائج الدراسة إلى: أن مستوى برامج التنمية المستدامة التى تلى تقدمها الجمعيات

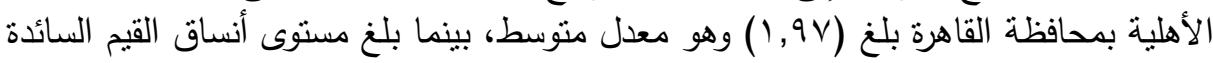

$$
\begin{aligned}
& \text { المجلد الخمسون، العدد الثامن، الجزء الأول، اغسطس بـr.r }
\end{aligned}
$$

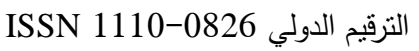

$$
\begin{aligned}
& \text { الترقيم الدولي الموحد الإلكتروني 3178-2636 }
\end{aligned}
$$




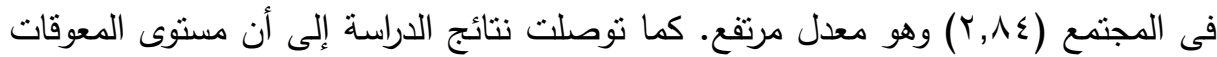

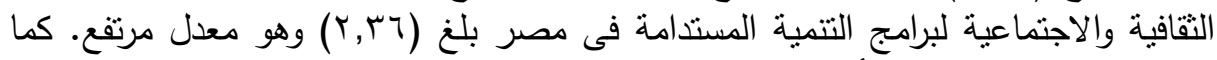

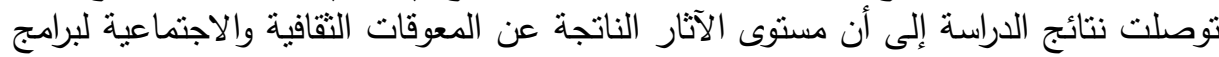

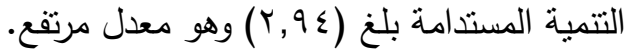

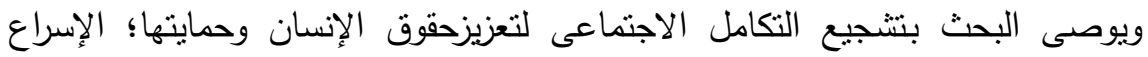

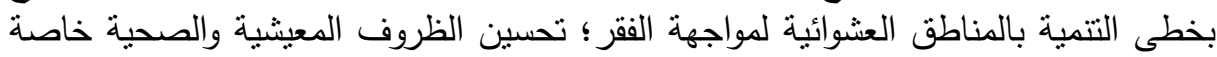
فى المناطق العشوائية؛ تقديم الدعم والتمويل اللازم للمشروعات والصناعنات الثرات الصغيرة والمتتاهية الصغر الصناف

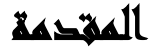

لقد استحوذ موضوع التتمية المستدامة على اهتمام العالم أجمع وبقوة منذ أواخر القرن

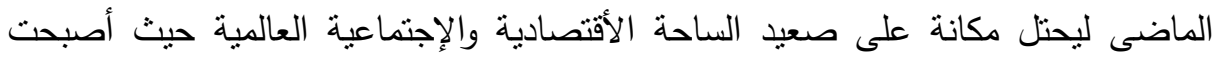
الإستدامة مدرسة فكرية تتنتر فى معظم العالم النامى والمتقدم على حد سواء. (أحمد عبد الإنئه

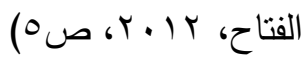

كما تعتبر التتمية المستدامة من أهم التطورات فى الفكر التتموى الحديث، وأبرز إضافة

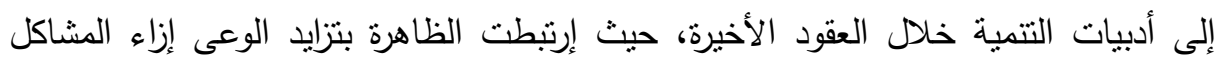

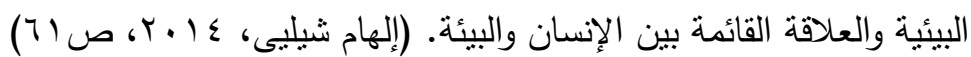

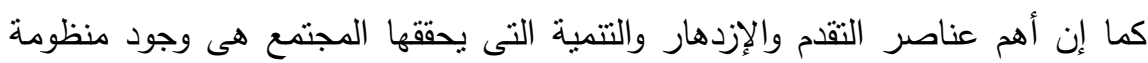
أخلاقية. فالقيم عبارة عن معايير منبثقة من تصور الفرد من المجتمع الذى يعيش فيه، بحيث بسترشد بها المرء ويحتكم بها، وفيها تحدد مجالات تفكيره وسلوكه وتؤثر فى تعلمه، وتختلف

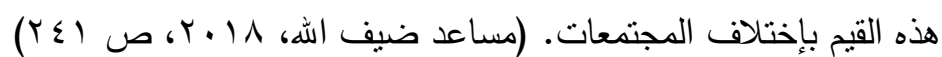
وفى ظل الانفتاح على دول العالم، تصبح منظومة القيم مستمدة من التقافة الثعبية حيث أن الثقافة لاتتثكل من فراغ، وإنما هناك عدد - ربما لاحصر لله من المؤثرات المادية واللامادية التى نسهم فى صياغتها. وفضلا عن ذلك هناك" إطار اجتماعى" تتفاعل فى ظله لهن

$$
\begin{aligned}
& \text { المجلد الخمسون، العدد الثامن، الجزء الأول، اغسطس Tr.r. } \\
& \text { النزقيم الدولي } \\
& \text { الترقيم الدولي الموحد الإلكتروني 3178-2636 }
\end{aligned}
$$


هذه المؤثرات لنتتج بنية الثقافة الثعبية بصورة تسمح بالتفاعل والتجديد المستمرين. (محمود

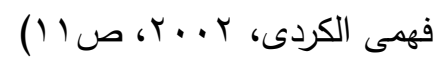

ومن ثم جاءت هذه الدراسة لتحديد المعوقات الثقافية والاجتماعية لبرامج التتمية

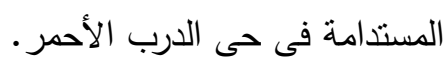

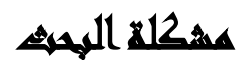

تم تحديد مشكلة الدراسة وصياغتها بعد عدد من الزيارات الاستطلاعية التى قام بها الباحثون وذلك للتعرف أكثر على مجتمع الدراسة على أرض الواقع والتعرف أكثر على طبيعة

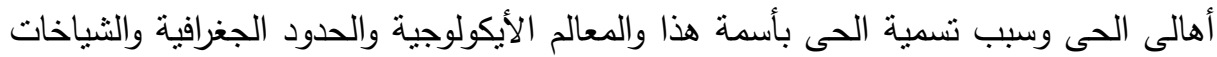
وإيكولوجيا الثوارع وأهم المعالم الموجودة بالحى والحرف التقليدية التى يثتهر بها حى الدرب التهاب الأحمر، بالإضافة إلى التعرف على الجمعيات والمؤسسات الأهلية التى تخدم الحى ودورهم

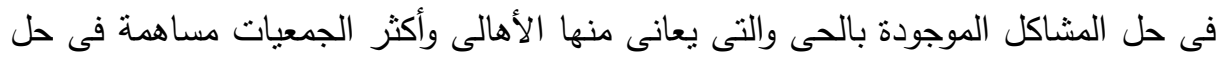

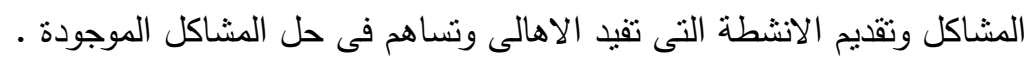
تعد مشكلة الدراسة بمثابة الإطار الفكرى الذى يلتقت فى رحابه المعالجات النظرية

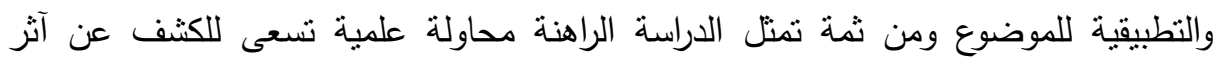

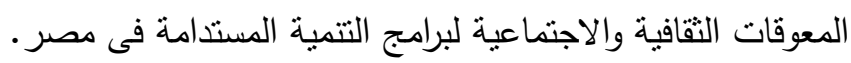
كما أن التتمية تعنى تغيرا شاملا يضطر معه المجتمع إلى التجاوز عن كل التقاليد والقيم

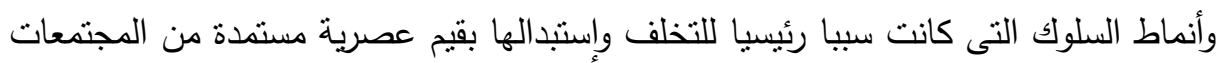
المتقدمة، بما يعنى أن النسق القيمفى المجتمعات النامية معوق أساسى للانقام. (محمد على

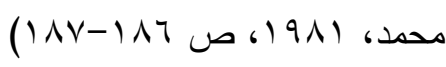

ولذلك تأثر الإنسان منذ فجر التاريخ بالعديد من الأسباب الاجتماعية والثقافية التى

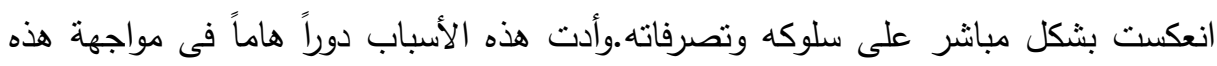

$$
\begin{aligned}
& \text { المجلد الخمسون، العدد الثامن، الجزء الأول، اغسطس ب. r. }
\end{aligned}
$$

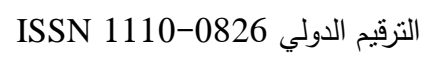

$$
\begin{aligned}
& \text { الترقيم الدولي الموحد الإلكتروني 3178-2636 }
\end{aligned}
$$


الأعباء لضمان استمراره وبقاءة ولقد أثر التغيير بكل أثنكاله (الاجتماعية والثقافية) على الثى

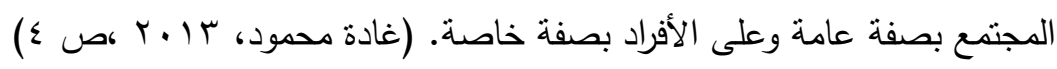

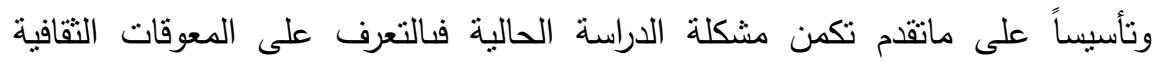
والاجتماعية التى تعوق عملية التتمية وذلك من خلال دراسة القيم السائدة والموروثات الشعبية بحى الدرب الأحمر وتحديد الآثار الناتجة عن المعوقات التقافية والاجتماعية وصولاًا إلى رؤية مقترحة لمواجهة هذه المعوقات.

\section{تمساولاهي المهنه}

(1) (اما برامج التتمية المستدامة التي تقدمها الجمعيات الأهلية بمحافظة القاهرة؟ (ץ)(أنساق القيم السائدة في المجتمع ومدى تأثثرها على برامج التتمية المستدامة؟

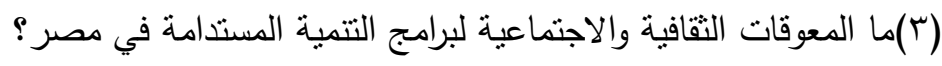

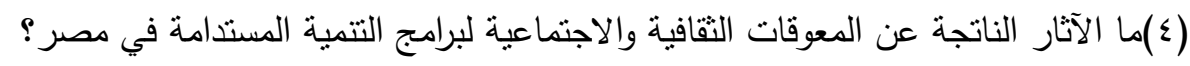

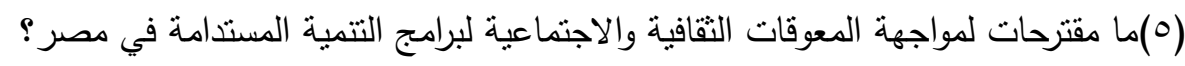
(7)ما أبعاد الروئة المستقبلية المقترحة لمواجهة المعوقات الثقافية والاجتماعية لبرامج التتمية

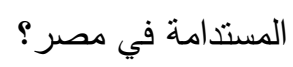

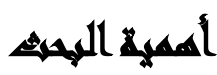

ولقد نم اختيار موضوع الدراسة لعدة اعتبارات تعكس أهمية الدراسة وتتقسم إلى أهمية نظرية وأهمية تطبيقية كالآتى: الأهمية النظرية: تمثل هذه الدراسة امتداداً لجهود الباحثين ممن نتاولوا فى بحوثهم ودراساتهم موضوع البحث ودور ذلك فى تشكيل إضافة معرفية لما كتب فى هذا الصدد فيمكن أن يكون

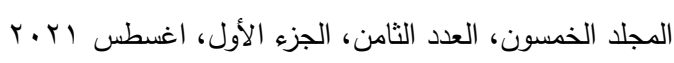

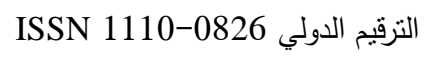

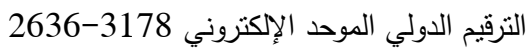




$$
\begin{aligned}
& \text { مجلة العلوم البيئية } \\
& \text { كلية الدراسات العليا والبحوث البيئية - جامعة عين شمس لجس } \\
& \text { نجلاء حسن الخولي وآخرون }
\end{aligned}
$$

هذا البحث مرجعاً للدراسات اللاحقة فى هذا المجال لما يثيره من قضايا وتساؤلات يمكن أن تؤخذ بعين الاعتبار .

الأهمية التطبيقية: وتتجلى أهمينة فى النتائج التى يثمر عنها التئث الحالى الذى يمكن

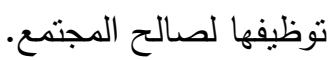

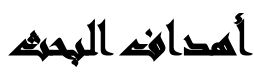

(1) (الحديد برامج التتمية المستدامة التي تقدمها الجمعيات الأهلية بمحافظة القاهرة. (r) (rحديد أنساق القيم السائدة في المجتمع ومدى تأثيرها على برامج التتمية المستدامة. (r) (r) (rديد المعوقات الثقافية والاجتماعية لبرامج النتمية المستدامة في مصر . (ع)تحديد الآثار الناتجة عن المعوقات الثقافية والاجتماعية لبرامج التتمية المستدامة في لئية (0)تحديد مقترحات لمواجهة المعوقات الثقافية والاجتماعية لبرامج التتمية المستدامة في مصر (T)التوصل إلى رؤية مستقبلية مقترحة لمواجهة المعوقات الثقافية والاجتماعية لبرامج التتمية

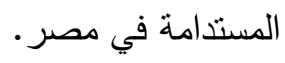

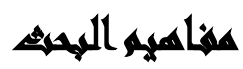

مفهوم المعوقات الثقافية والاجتماعية: المعوقات: تعنى كلمة المعوقات فى اللغة عقبة، عائق، حائل، ويعرف قاموس ويبستر المعوقات: العثرات والأثياء التى تقف وتحول دون لعن

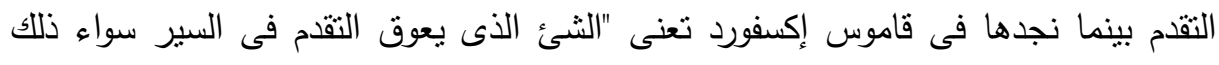

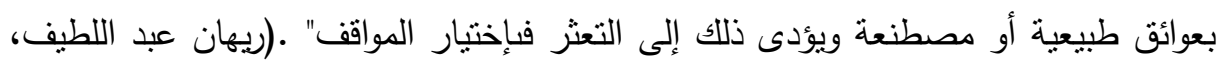

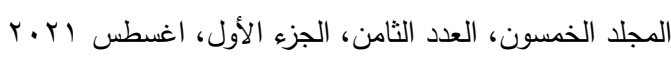

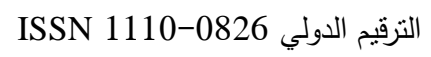

$$
\begin{aligned}
& \text { الترقيم الدولي الموحد الإلكتروني 3178-2636 الدرلي }
\end{aligned}
$$




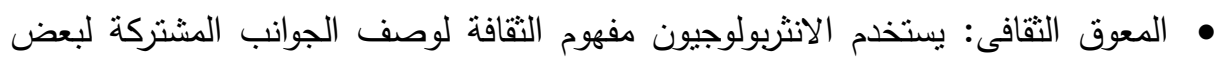

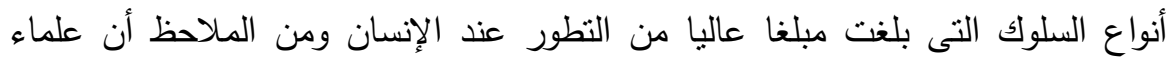
الأثنربولوجيا ينظرون إلى الثقافة بشكل أكثر اتساعا من علماء الاجتماع .(مصطفى الإنى

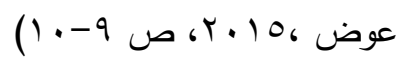

ومن أقدم التعريفات وأكثرها شيوعا حتى الآن تعريف أدوارد تايلور الذى فى كتابة: "الثقافة البدائية بأنها ذلك الكل المركب الذى يشمل المعرفة والمعتقدات والفن والأخلاق والقانون والأعراف والقدرات والعادات الآخرى التى يكتسبها الإنسان بإعنباره عضوا فئ والثى

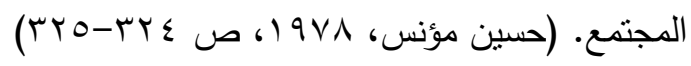
ه المعوق الاجتماعى: المعوق الاجتماعى هو العامل الاجتماعى - أى المرتبط بالمجتمع -

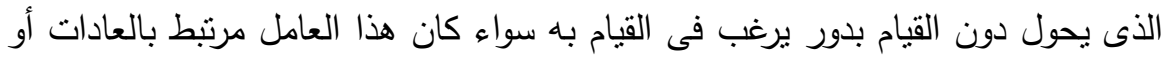

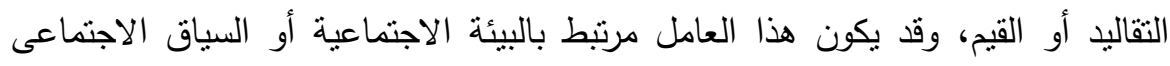
سواء كان ريفى أو حضرى وقد يكون من داخل الأسرة كما قد يكون من خارجها. (ريهان

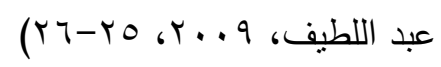

التعريف الإجرائى للمعوقات الثقافية والاجتماعية: "هى الصعوبات التى تسبب الفجوة بين الإنجاز المتوقع والإنجاز الفعلى مما يحول دون تحقيق الأهداف بكفاية وفاعلية". مفهوم برامج التنمية المستدامة: قد طرحت فكرة التتمية المستدامة لأول مرة فى اللجنة التهات العالمية للتنمية والبيئة المعروفة بالجنة برتدتلاند عام 9ANV التى عرفت التتمية المستدامة

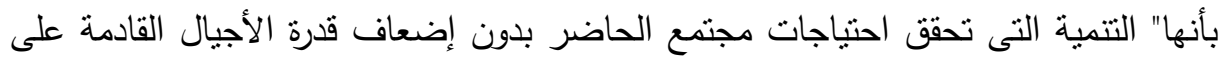

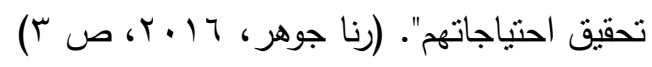

وقد عرف ريز سنة 1911 التتمية المستدامة بشكل آخر "التنمية المستدامة هى تغيير اجتماعى اقتصادى إيجابى، لا يغفل النظم الإيولوجية والاجتماعية التى تقوم عليها المجتمعات

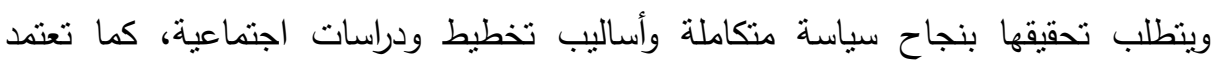
76

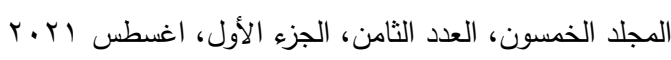

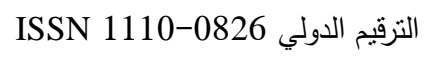

$$
\begin{aligned}
& \text { الترقيم الدولي الموحد الإلكتروني 3178-2636 }
\end{aligned}
$$


حيويتها على التأييد الكامل للناس الذين تؤثر عليهم من خلال حكوماتهم وأنشطتهم الخاصة".

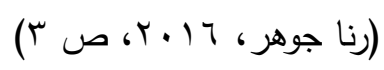

التعريف الاجرائى لمفهوم التتمية المستدامة: "هى ضمان حقوق الأجيال المقبلة فى الموارد البيئية من خلال إستراتيجية واضحة وحسن إدارة وتتظيم للموارد المتاحة وتحسين فرص الحياة

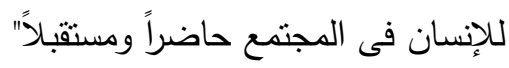

مفهوم نسق القيم: يرى سعد الدين إبراهيم: أن النسق القيمى هو مجموعة من القيم

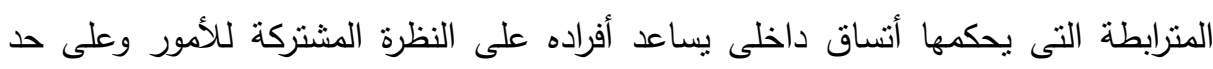

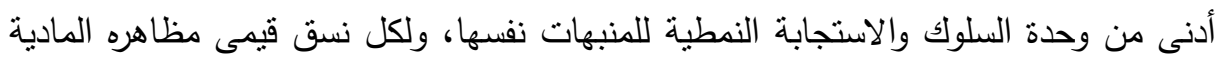

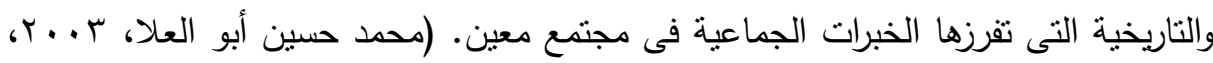
ص ص or or or المفهوم الإجرائى لنسق القيم: هى مجموعة من المعتقدات والتصورات التى يفسر يها

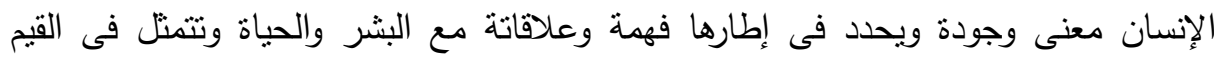
النظرية وهى التى تهتم بالمعرفة والحقيقة والقيمة الاقتصادية التى تهتم بالمعرفة والحقيقة والقيمة الاقتصادية التى تهتم بما يفيد الآخرون وينفعهم والقيمة الدينية التى ترفع من شأن المعتقات والمشاعر والقيمة الجمالية التى تهتم بالثكل والتتاسق والقيمة الاجتماعية التى تهتم بما يفيد الآخرين والقيمة السياسية التى ترفع من شأن المركز الاجتماعى والسلطة. الموروثات الشعبية: إن مصطلح الفلكلور مصطلح إنجليزى Flklore قام بصياغتة عالم الآثار الإنجليزى جونز تومز W.G.THams فى عام \& \&1/م ليدل على دراسة العادات

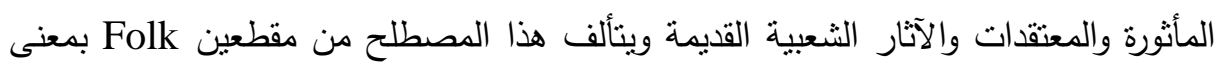
الناس وLore بمعنى حكمة أو معرفة الكلمة حرفياً أو معارف الناس أو حكمة الشعب.

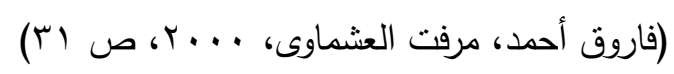

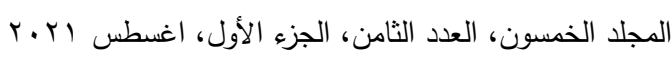

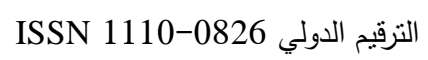

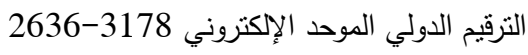


نستطيع القول إن التراث الثعبى بمثابة بطاقة التعريف لأى شعب من الثعوب تسنطيع

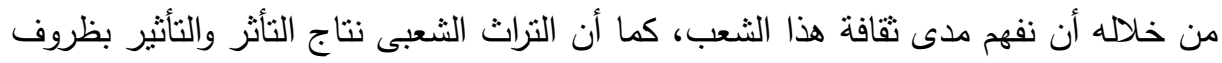

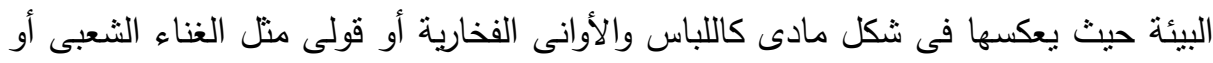

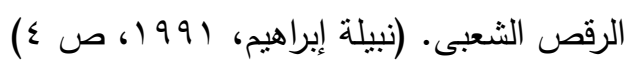
المفهوم الإجرائى للموروثات الثعبية: هو كل ما يرتبط بالجانب المادى وخاصة الحرف الحرف التقليدية الممنلة فى حرفة الخيامية والتطعيم بالصدف والاثشغال اليدوية والدور الذى تلعبه

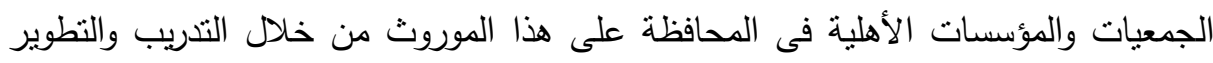

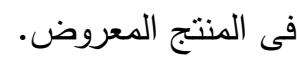

\section{السواساهي الماريخ}

يهدف فصل الدراسات السابقة لمعرفة الباحث بالنتائج التى توصل إليها الباحثون

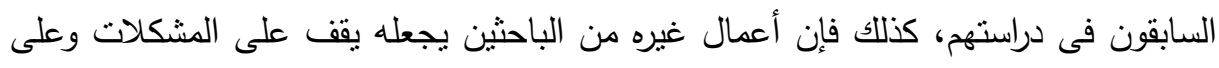
الحقائق والمفاهيم والنظريات التى تهمه فى بحثه وفى ضوء ذهي ذلك قامت الباحثة بتصنيف هذه الدراسات حسب وحده الموضوع إلى ثلاث محاور كما يلى : الاراسات السابقة التى تناولت "التتمية المستدامة": أجرى وليد الثعبي (1 ا + r) دراسة بعنوان: مدى تضمين مجالات التتمية المستدامة في كتاب العلوم للصف الثاني المتوسط في المملكة العربية السعودية. وقد هدفت الدراسة إلى تعرف مدى تضمين مجالات التتمية المستدامة في كتاب العلوم التحليلي للصف الثاني المنوسط في المملكة العربية السعودية. واستخدمت الدراسة المنهج الوصفي التحليلي. وقد تم اعتماد الأفكار مكتملة المعنى كوحدات للتحليل. ولتحقيق هدف

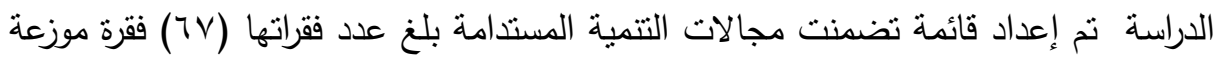

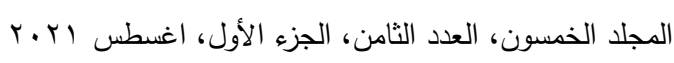

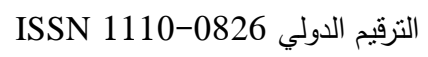

$$
\begin{aligned}
& \text { الترقيم الدولي الموحد الإلكتروني 3178-2636 }
\end{aligned}
$$


على ثلاث مجالات هي: المجال البيئي، والمجال الاقتصادي، والمجال الاجتماعي ثم التأكد من صدقها وثباتها.

وأظهرت نتائج الدراسة: أن معدل نكرارات مجالات التتمية المستدامة التي وردت فيكتاب

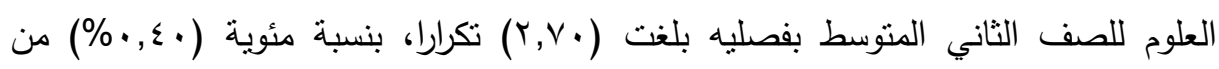

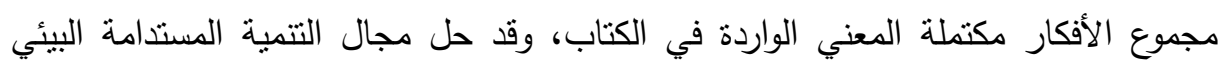
بالتزتيب الأول.

وقد خلصت الدراسة إلى مجموعة من التوصيات، من أبرزها مراعاة مجالات التتمية

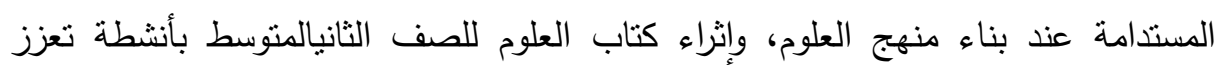
مجالات التتمية المستدامة.

التعليق على الدراسة: نتين هذه الدراسة مدى أهمية ضم التتمية المستدامه داخل الكتب

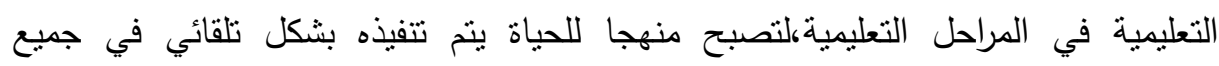
المجالات.

(لاري ليثمك، حنا سالو، رويرت ليبينيز، ليوني بوتنر، جيري مستجوكي) بمجلس البحوث

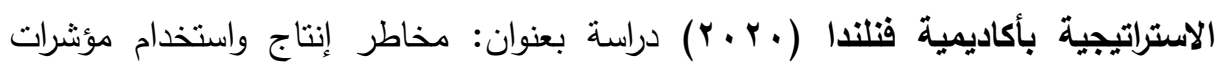
أهداف التتمية المستدامة.

وقد هدفت هذه الدراسة إلى إبراز أهداف التتمبة المستدامة (SDG) المتمثلة في تزويد البشرية بخريطة طريق عالمية للاستدامة حيث تم نطوير المؤشرات الرسمية لأهداف التتمية

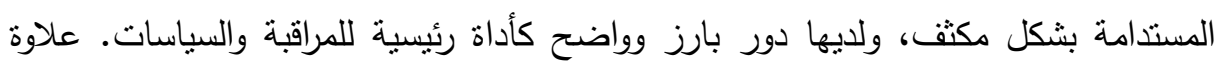
على ذلك، تم إدخال مجموعات مختلفة من المؤشرات التكميلية أو البديلة على المستويات العالمية والإقليمية والوطنية. وقد ركزت هذه الدراسة على المخاطر المتعلقة بالمؤشرات الوطنية. حيث يعتمد التحليل على الخبرات المكتسبة من عمليات إعداد مؤشرات التتمية المستدامة في فنلندا والرؤى من المتخصصين في المؤشرات وأصحاب المصلحة في فنلندا

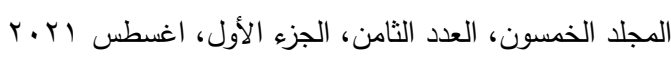

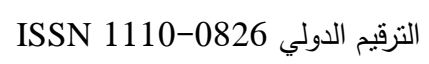

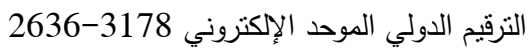


وألمانيا. كما تم تحليل المخاطر المتعلقة بالإفراط في استخدام المؤشرات، وعدم استخدامها

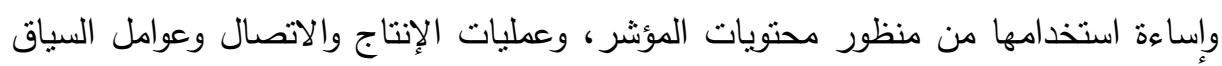
الخارجية. كما تم مناقثة فرص تجنب المخاطر المختلفة وتحسين الآتار المجتمعية والتأثنرات لاستخدام المؤشرات. فمفهوم الخطر مفيد من حيث التتخيص التجريبي وصياغة توصيات التخفيف.

التعليق علي الاراسة: تعد هذه الدراسة من الدراسات المهمة التي تتاولت المخاطر التي تهدد التتمية المستدامة العالمية بشكل عام من خلال الاستتاد على مجموعة من المؤشرات وأن

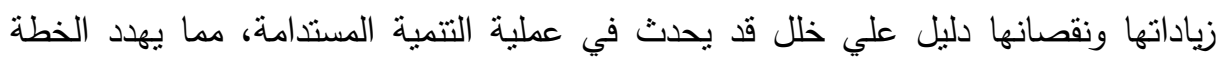

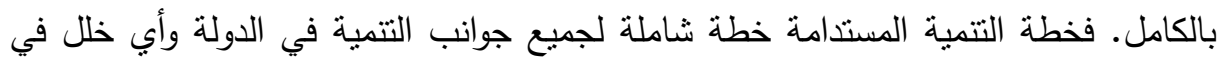
أي جزء منها يعطل مسيرة التتمية بالكامل. بالكا.

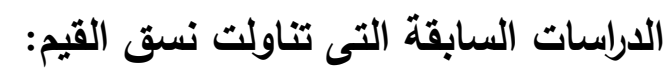

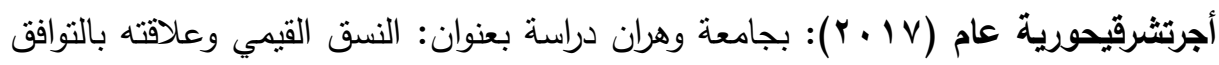
النفسي والاجتماعي لدى طلبة المراحل المتوسطة والثانوية- دراسة ميدانية بالمدارس المتوسطة دئة والثانوية لمدينة مستغانم.

وقد هدفت الدراسة إلى معرفة العلاقة بين القيم والتوافق النفسي الاجتماعي لدى طلبة المرحلة المتوسطة والثانوية لدى عينة مكونة من ( . . 7) طالب وطالبة تم اختيارهم بطريقة

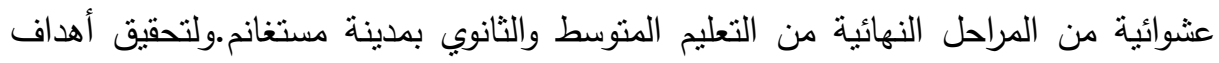

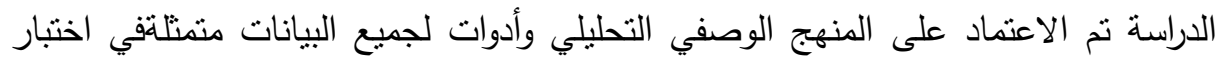

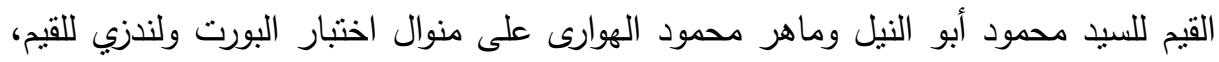
ومقياس التوافق الاجتماعي من إعداد سهير إبراهيم. 
وبعد تحليل البيانات توصلت الدراسة إلى النتائج التالية: ترتبت القيم تتازليا لدطلبة

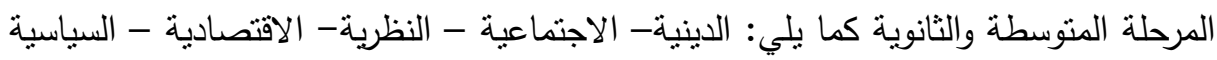

كما أظهرت النتائج أن ترتيب القيم لدى ذوي التوافق النفسي الاجتماعي المرتفع كما يلي:

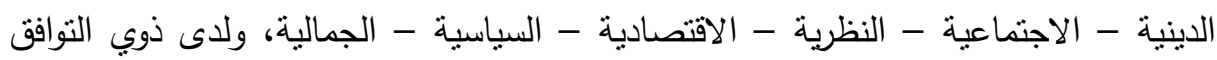
النفسي الاجتماعي المنخفض كما يلي: الدينية - الاجتماعية - الاقتصادية- النظرية السياسية - الجمالية.

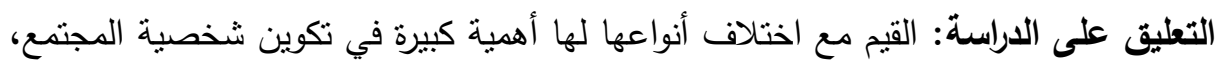
كما تكثف مدى أهمية الدور الذي تلعبه في التأثثر على عملية نوافق الإنسان نفسيا

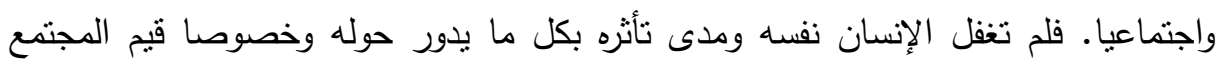

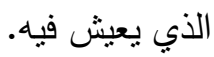

أجرى ساكت بيهاري (10 + ب) دراسة بعنوان: دراسة نمط القيمة لمعلمي المدارس الثانوية.

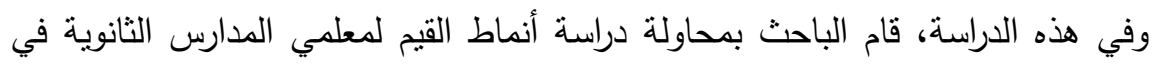
شرق دلهيوتم اختبار ، A معلم مدرسة ثانوية من 7 مدارس حكومية باستخدام تقنيات عشوائية بسيطة. وقد كثفت هذه الدراسة في نتائجها التي نوصلت إليها عن عدم وجود فروق ذات دلالة إحصائية في منوسطات الدرجات على أبعاد القيم للمعلمين - القيم النظرية والاقتصادية والجمالية والاجتماعية، بينما وجدت فروق ذات دلالة إحصائية في القيم السياسية والدينية. التعليق على الدراسة: يمثل المعلم في مرحلة المدار الثانوية عاملا مؤثرا جدا في المجتمع دئم حيث ينولد عنه طريقة تفكير جيل يخرج من تحت يديه ليدخل المرحلة الأخيرة من التعليم

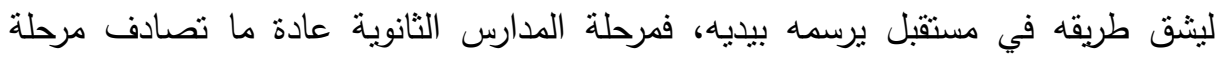
المراهقه بكل تغيراتها النفسية والفسيولوجية بما فيها من اضطرابات تجعل المراهق غير منيه منزن

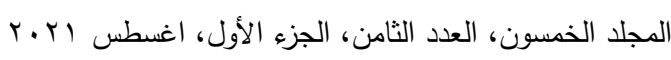

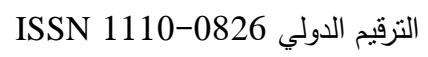

$$
\begin{aligned}
& \text { التزقيم الدولي الموحد الإلكتروني 3178-2636 }
\end{aligned}
$$


بالكامل لأخذ قرارات مصيرية في حياته. ومن هنا تأتي أهمية نسق القيم الخاص بالمعلم، لأنه

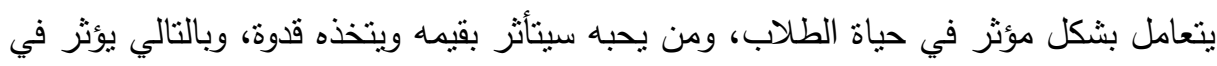

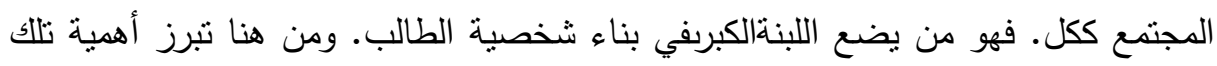
الدراسة.

\section{الدراسات السابقة التى تثاولت الموروثات الشعبية:}

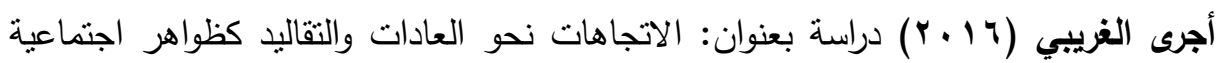
في المجتمع الأردني.

هدفت الدراسة إلى التعرف على الاتجاهات نحو العادات والتقاليد الخاصة بالأفراح

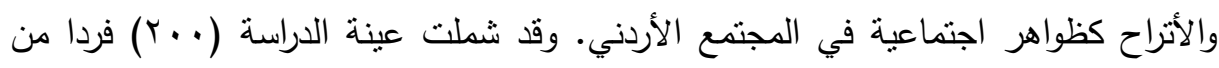

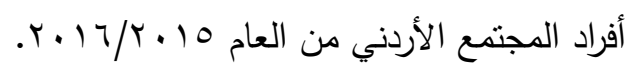
وقد أثنارت النتائج إلى أن درجة الاتجاهات نحو العادات والثات التقاليد (عادات الأفراح

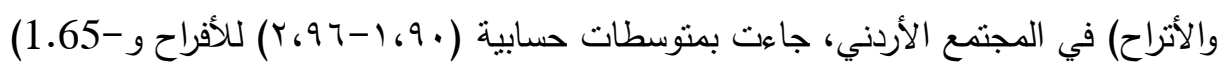
(2.95 للأتراح أي بدرجة مرتفعة إلى متوسطة، كما أظهرتالنتائجعدم وجود فروق ذات الت دلالية

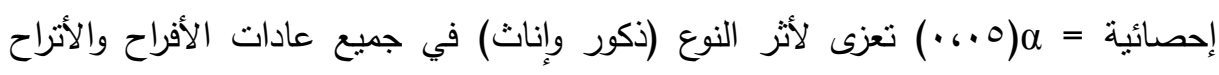
باستثناء العادة (تعتمد الجاهة في عادات طلب العروس من قبل أهل العز العريس)، ولصالح الذكور والعادة (يقوم أهل العروس بعمل ليلة الحناء لها ولصديقاتها)، (والعادة ما زالت قائم

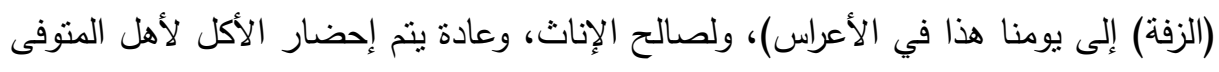
من قبل الأصدقاء والأقارب)، وعادة زيارة أهل المتوفى يومي الإثتين والخميس (للنساء) أربعين

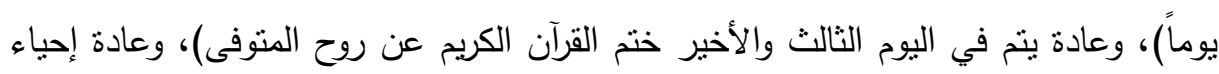

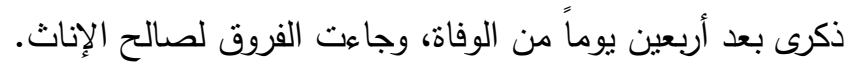

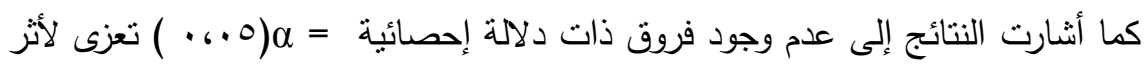

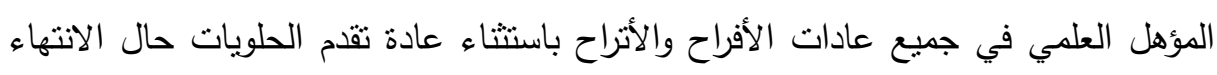

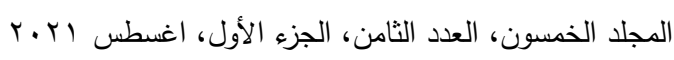

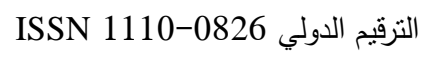

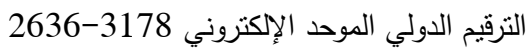


من الموافقة وقراءة الفاتحة، ولصالح أعلى من ثانوي، وعادة تفضيل بعض العائلات أن يعيش العريس مع أهله في نفس المنزل، ولصالح ثانوي فأقل، وعادة أن تثم التعزية ثلاثة أيام فقط أنط

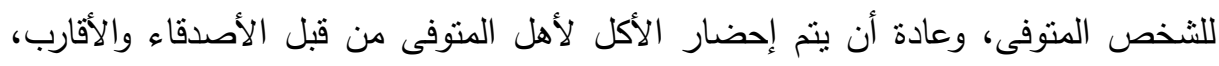
وعادة يتم في اليوم الثالث والأخير ختم القران الكريم عن روح المتوفى)، وجاءت الأن الفروق لصالح ثانوي فأقل.

التعليق علي الدراسة: نشير هذه الدراسة إلى كم العادات والتقاليد الموروثه في المجتمعات

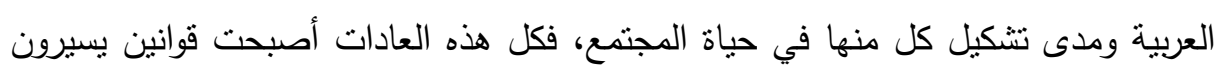
عليها جيلا بعد جيل دون السؤال عن أصل ثلاك العادات.

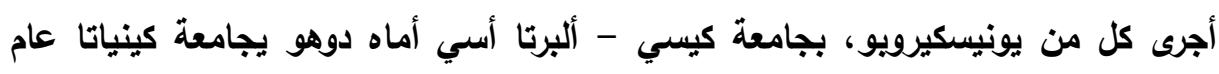

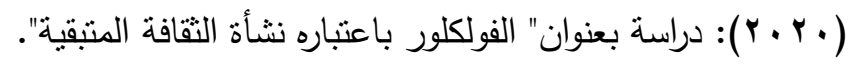

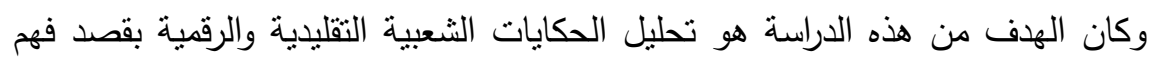
كيفية تأسيس معاني وقيم الحكايات الثعبية الأفريقية. حيث تبنت طريقة مراجعة أدبيات سطح المكتب (دراسة مكتبية). وقد تضمن ذلك مراجعة متعمقة للدراسات المتعلقة بالفولكلور كظاهرة ذات طابع متبقي. نم تنفيذ ثلاث مراحل للفرز حول الموضوع قيد الدراسة، أي الفولكلور

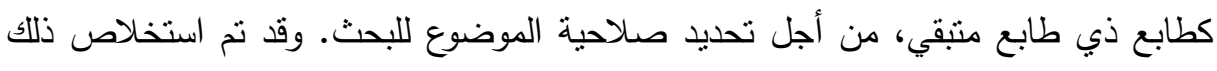

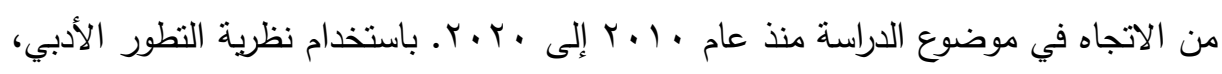
فحللت الورقة كيف يتم التعبير عن الممارسات الثقافية والتقاليد والعادات وممارستها في الثكل بلتهل

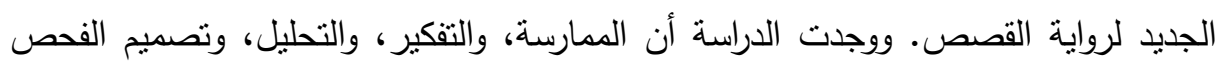

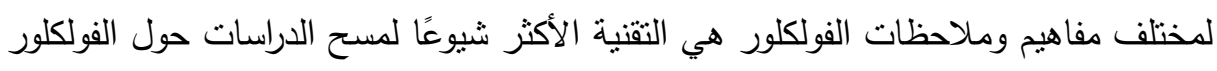
كظهور للافقة المنققية. وكثفت غالبية الدراسات من التحليل عن وجود علاقة إيجابية للفلكلور في الثقافة الحديثة. وهذه دراسة أولية في معظم البلان الأفريقية يمكن أن يستخدمها مؤلفون

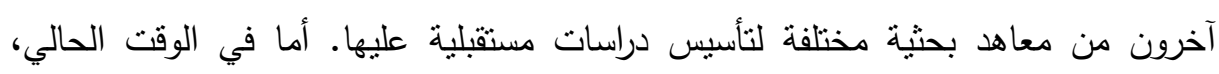

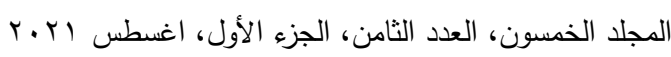

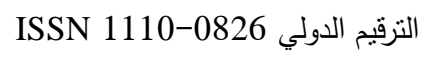

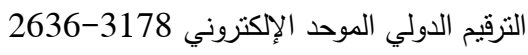


فيجب الحفاظ على الفولكلور في الثقافات المختلفة في مختلف الدول من أجل الاستفادة من التكنولوجيا متل الإنترنت كوسيلة لتعليم القيم الأخلاقية والثقافية للأطفال والأجيال القادمة.

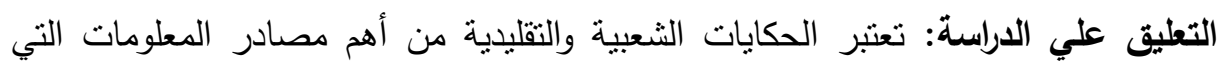
نتعرف من تحليلها على عادات وتقاليد هذا الشعب، وهذه من أهم الدراسات المطولة التي لتئي قامت بتحليل الفلكلور أو الموروثات الشعبيةمن خلال قصص واتهات وحكايات يقومون بروايتها.

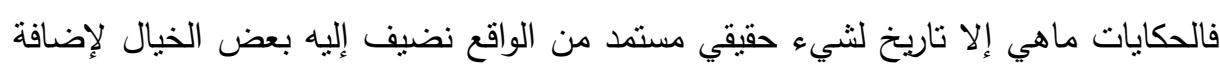
الإثارة والنتويق حتى تصبح الحكاية أكثر إمتاعا لمن يستمع إليها.

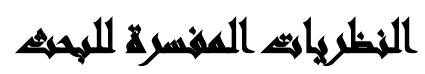

\section{النظريات المفسرة للتنمية المستدامة:}

نظرية الحداثة والتحديث: لقدحاولت نظرية التحديث باعتبارها مرحلة من مراحل تطور نظرية

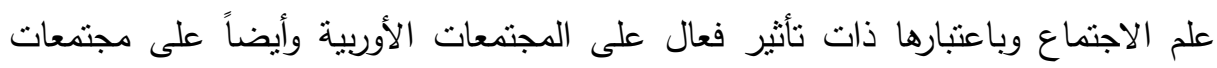

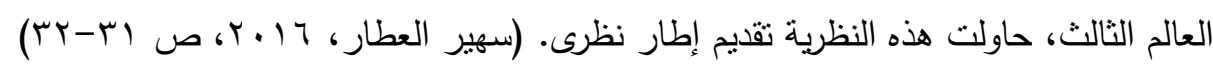

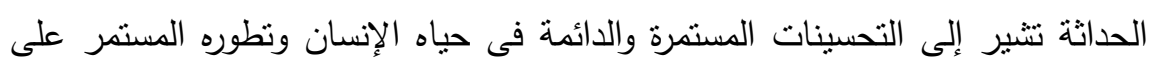
عكس الأثياء التقليدية التى تنقى فى العالم الحديث وأصبح التغير، والتغيير، والتطور التئن

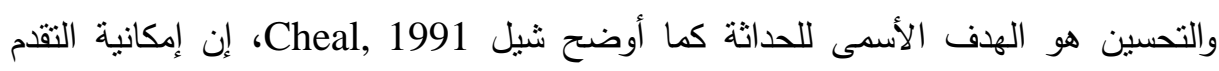
تعنى الاعتقاد بأن الأشياء غداً سوف تكون أفضل مما هى علية اليوم، والتى تعنى بالتالى التى

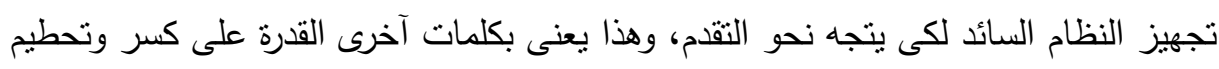

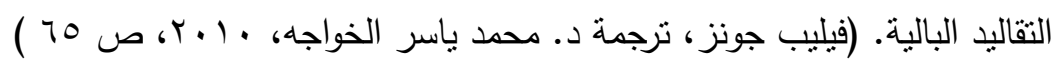


- تأكد النظرية أن سبب تخلف المجتمعات النامية يرجع إلى العوامل التقافية والاجتماعية والتى تمثل عائق وتمنعها من اللحاق بالغرب، لتحقيق التتمية والتقدم لابد من إزالة هذه

- تتبنى نظرية التحديث التفكير الايجابى وتحسين الظروف الإنسانية وتحطيم التقاليد البالية. - ترى النظرية أن احتمالية التقدم تتبثق من الإيمان بقوة البشر فى التفكير بأنفسهم وأحوالهم

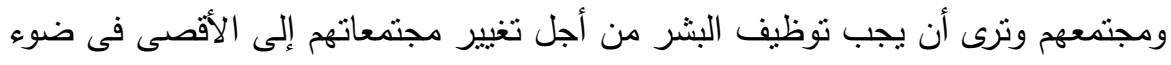

\section{النظريات المفسرة لنسق القيم السائدة:}

نظرية الصراع الاجتماعى: تأخذ نظرية الصراع الاجتماعى أثنكالا مختلفة فى الفكر السياسى

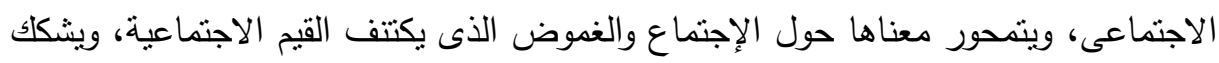
بعض المفكرين فى وجود اجماع هذه القيم، ويذهبون إلى أن هذه القيم لاتعكس كل المصالح

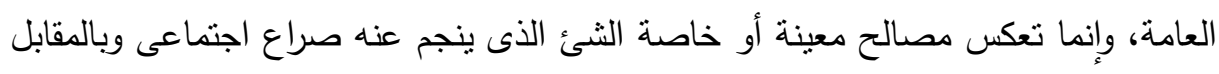
يؤمن البعض بوجود قيم مشتركة، ويغض الطرف عن الصراع ووسائل تطويقة بالقوة.( الأزهر

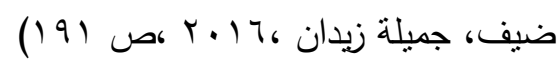
التعقيب: يرى نموذج الصراع أن المشكلة الاجتماعية ناجمة عن فنثل النظم الاجتماعية والثقافية القائمة، ويرون أن المشكلة عبارة عن صراع بين القيم فهناك قيم تسبب مشكلات وقيم آخرى غير مرغوب فيها.

\section{النظريات المفسرة للموروثات الشعبية:}

النظرية البنائية الوظيفية: يعتمد الاتجاه البنائى الوظيفى بصفة أساسية على فكرة النسق،

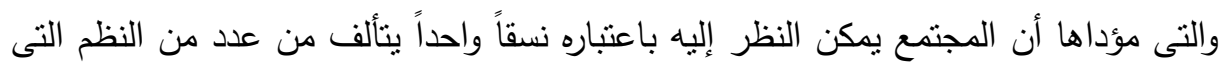

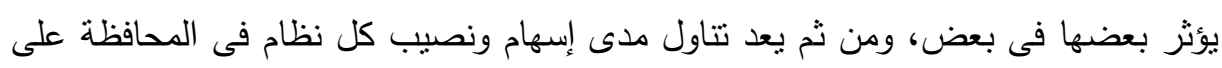

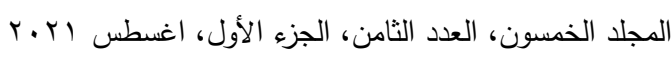

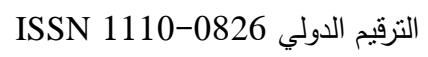

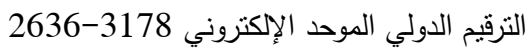


تماسك ذلك المجتمع من أجل استمراره أحد المحاور الأساسية فى هذا الاتجاه. (نجوى

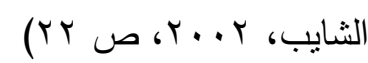

فالبنائية ترى أن المجتمع يتكون من عناصر مترابطة تتجه نحو التوازن من خلال توزيع

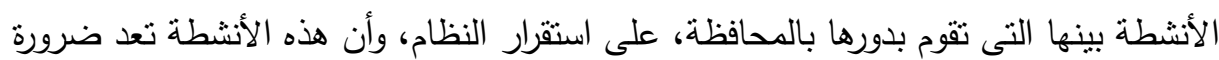

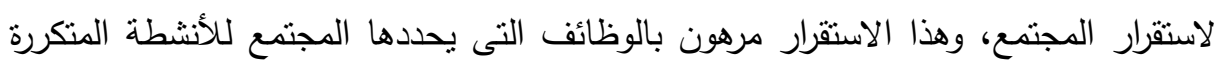

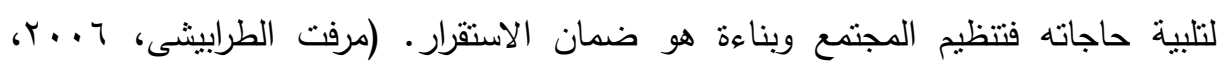
(1) ص التعقيب: تدور الفكرة الرئيسية للإتجاه الوظيفى حول وجود نسق يتكون من عدة أنظمة أو

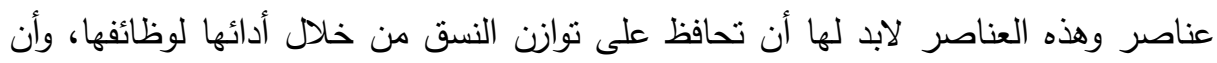
أى تغيير فى أداء هذه الوظائف سوف يؤدى إلى إختلال توازن النسق ونشوء المشناكل فيه. كذلك إن البناء الاجتماعى هو فى الأساس يتكون من مجموعة من العلاقات الاجتماعية التى تتفاعل مع بعضها البعض وتساهم فى أداء المجتمع لوظائفة.

\section{الاجزاعايه المنهجية للهيهيد}

نوع الدراسة: تنتمي هذه الدراسة إلي الدراسات الوصفية التحليلية، حيث تتميز البحوث

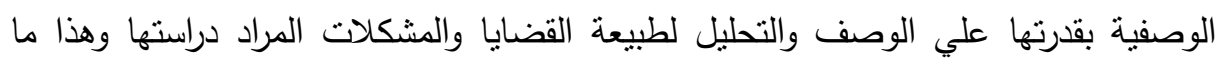
ينطوي عليه البحث الراهن.

المنهج المستخدم: انساقاً مع نوع هذه الدراسة، وما ترمي إليه من أهداف، فإن الدراسة

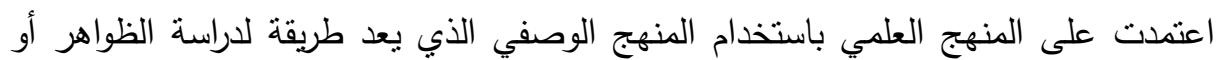

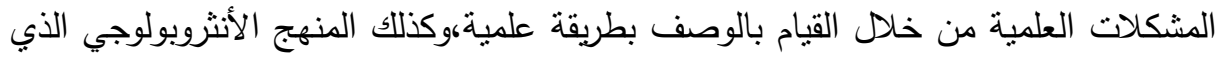
يسعى لدراسة مجرى النطور الإنساني من الناحيتين البيولوجية والثقافية والقوانين والمبادئ التي 
تحكم هذا التطور والارتباطات التي بين الجوانب الطبيعية المختلفة للإنسان وبين عادات الثعوب في الماضي والحاضر والأنماط التي تميز مجتمعات معينة دون غيرها.

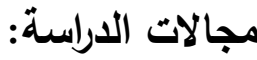

المجال المكاني: تمثل المجال المكاني للاراسة في مؤسسة مظلة للتتمية الاجتماعية وجمعية وسط لتتمية المجتمع المحلى بحي الدرب الأحمر بمحافظة القاهرة. المجال البشري: تمثل المجال البشري للاراسة في عينة عمدية من المستقيدين (الذكور والإناث) في الفئة العمرية (11-10) سنة بمؤسسة مظلة للتنمية الاجتماعية وجمعية وسط

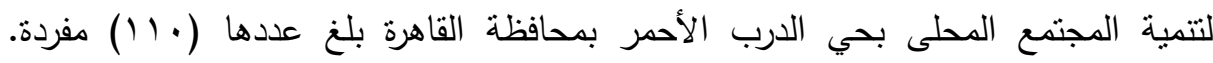
وتوزيعها كالتالي.

جدول (1): يوضح نوزيع المستفيدين المجال البشري للدراسة

\begin{tabular}{|c|c|c|}
\hline عدد المستفيدين & البيان & 5 \\
\hline 00 & مؤسسة مظلة للتتمية الاجتماعية بحي الدرب الأحمر بمحافظة & 1 \\
\hline 00 & جمعية وسط لتنمية المجتمع المحلى بحي الدرب الأحمر بمحافظة & $r$ \\
\hline 11. & الإجمالي & \\
\hline
\end{tabular}

المجال الزمني: وهي الفترة التي استغرقتها عملية جمع البيانات من الميدان وذلك من 19/1/1

$$
\text { أدوات الدراسة: نمثلت أدوات جمع البيانات في: }
$$

• استمارة استبيان للمستفيدين حول المعوقات الثقافية والاجتماعية لبرامج التتمية المستدامة

$$
\text { في مصر • وتم تصميم الأداة وفقاً للخطوات النالية: }
$$

تم تحديد الأبعاد التي تشتمل عليها استمارة استبيان المستفيدين والتي تمثلت في خمسة التهات

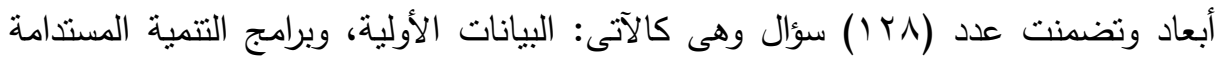

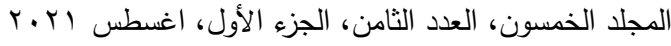

$$
\begin{aligned}
& \text { التزقيم الدولي 0826- ISSN 1110 } \\
& \text { الترقيم الدولي الموحد الإلكتروني 3178-2636 }
\end{aligned}
$$


التي تقدمها الجمعيات الأهلية بمحافظة القاهرة، وأنساق القيم السائدة في المجتمع ومدى تأثثرها على برامج التتمية المستدامة، والموروثات الثتعبية السائدة في المجتمع ومدى تأثيرها على برامج التتمية المستدامة، والآثار الناتجة عن المعوقات الثقافية والاجتماعية لبرامج التثمية المستدامة في مصر • وذللك كما يلي: جدول (Y): يوضح نوزيع عبارات استمارة استبيان المستقيدين

\begin{tabular}{|c|c|c|c|}
\hline أرقام العبارات & عدد الأسئلة/ العبارات & الأبعاد & r \\
\hline $9-1$ & 9 & البيانات الأولية & 1 \\
\hline$r \wedge-1$ & r^ & برامج التتمية المستدامة الني تقدمها الجمعيات & r \\
\hline$\leqslant 1-1$ & « & 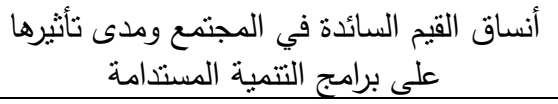 & r \\
\hline$\varepsilon r-1$ & $\varepsilon r$ & 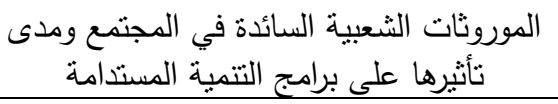 & $\varepsilon$ \\
\hline$v-1$ & V & 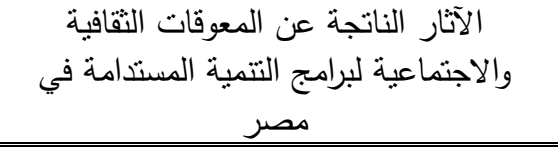 & 0 \\
\hline
\end{tabular}

ا. صدق الأداة:

(أ) الصدق الظاهري (صدق المحكمين): تم عرض الأداة على عدد (• (1) من أعضاء هيئة التدريس بجامعة أم القرى بالمملكة العربية السعودية، وجامعة عين شمس، وجامصنة القاهرة، وجامعة حلوان، وجامعة أسوان، وجامعة الفيوم، والمعهد العالي للخدمة الاجتماعية لهانه بالقاهرة، لإبداء الرأي في صلاحية الأداة من حيث السلامة اللغوية للعبارات من ناحية

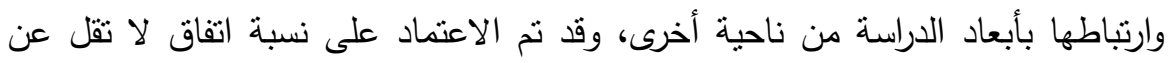
( •^\%)، وقد تم حذف بعض العبارات وإعادة صياغة البعض، وبناء على ذلك تم صياغة الاستمارة في صورتها النهائية. 


$$
\begin{aligned}
& \text { مجلة العلوم البيئية } \\
& \text { كلية الدراسات العليا والبحوث البيئية - جامعة عين شس البئ } \\
& \text { نجلاء حسن الخولي وآخرون }
\end{aligned}
$$

(ب) صدق المحتوى "الصدق المنطقي": وللتحقق من هذا النوع من الصدق قامت الباحثة بما

- الإطلاع علي الأدبيات والكتب، والأطر النظرية، والدراسات والبحوث السابقة التي نتاولت

$$
\text { بأبعاد الدراسة. }
$$

- - تحليل هذه الأدبيات والبحوث والدراسات وذللك للوصول إلي الأبعاد الدختلفة والعبارات

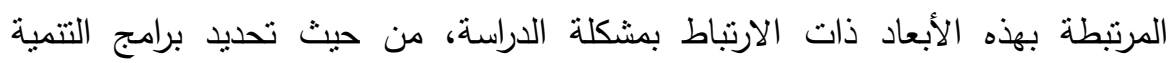

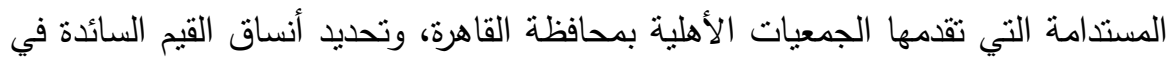
المجتمع ومدى تأثثرها على برامج التتمية المستدامة، وتحديد الموروثات الثعبية السائدة في المجتمع ومدى تأثثرها على برامج التتمية المستدامة، وتحديد الآتار الناتجة عن بن

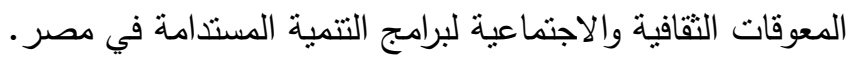
(ج) صدق الاتساق الداخلي: اعتمدت الباحثة في حساب صدق الاتساق الداخلي على معامل

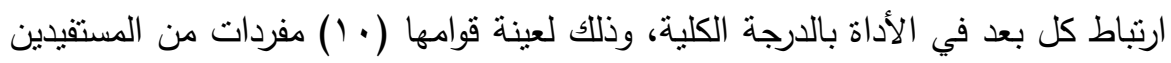

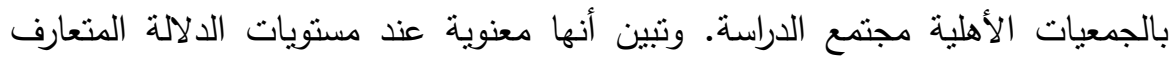
عليها، وأن معامل الصدق مقبول، كما يتضح من الجدول التالي.

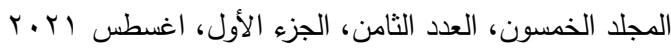

$$
\begin{aligned}
& \text { النزقيم الدولي } \\
& \text { الترقيم الدولي الموحد الإلكتروني 3178-2636 }
\end{aligned}
$$


كلية الدراسات العليا والبحوث البيئية - جامعة عين شمس البئة

نجلاء حسن الخولي وآخرون

جدول (r): الاتساق الداخلي بين أبعاد استمارة استبيانالمستقيدين ودرجة الاستبيان ككل $(1 \cdot=\dot{)})$

\begin{tabular}{|c|c|c|c|}
\hline الالالة & معامل الارتباط & الأبعاد & م \\
\hline * * * & $\cdot, V \leqslant 0$ & برامج التتمية المستدامة التي تقدمها الجمعيات الأهلية & 1 \\
\hline *** & $\cdot, 107$ & 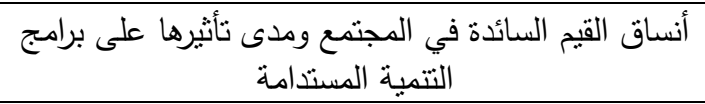 & $r$ \\
\hline$* *$ & ., $\vee 09$ & الموروثات الثعبية السائدة في المجتمع ومدى تأثيرها على المتئية & $r$ \\
\hline *** & $\cdot, \wedge \leq 9$ & الآثار الناتجة عن المعوقات الثقافية والاجتماعية لبرامج & $\varepsilon$ \\
\hline
\end{tabular}

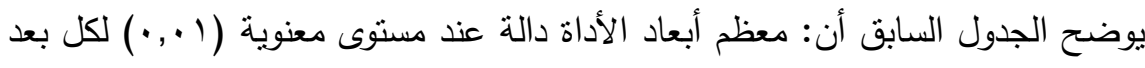
على حدة،ومن ثم تحقق مستوى التقة في الأداة والاعتماد على نتائجها. r. ثبات الأداة: تم حساب ثبات الأداة باستخدام معامل ثبات (ألفا ـ كرونباخ) لقيم الثبات

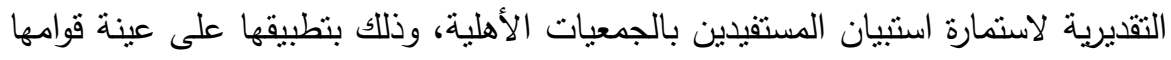

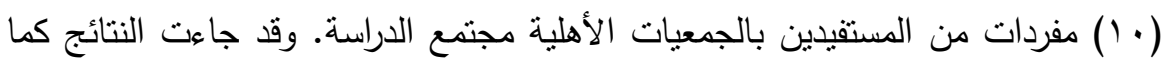
هي موضحة في الجدول التالي. 
جدول (؛): يوضح نتائج ثبات استمارة استبيانالمستفيدين باستخدام معامل (ألفا ـ كرونباخ) $(1 \cdot=0)$

\begin{tabular}{|c|c|c|}
\hline معامل (ألفا ـ كرونباخ) & الأبعاد & 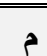 \\
\hline •, ^ & برامج التتمية الكستدامة التي تقامها الجمعيات الأهلية بمحافظة & 1 \\
\hline$\cdot, \Lambda 1$ & أنساق القيم السائدة في المجتمع ومدى تأثيرها على برامج التنتية & r \\
\hline . & الموروثات الشعبية السائدة في المجتمع ومدى تأثيرها على برامج & r \\
\hline$\cdot, 91$ & الآثار الناتجة عن المعوقات الثقافية والاجتماعية لبرامج التنمية & $\varepsilon$ \\
\hline$\cdot, A V$ & ثبات استمارة استييانالمستقفيدين بالجمعيات الأهلية ككل & \\
\hline
\end{tabular}

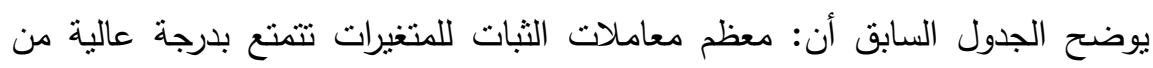

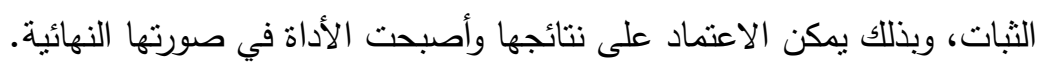

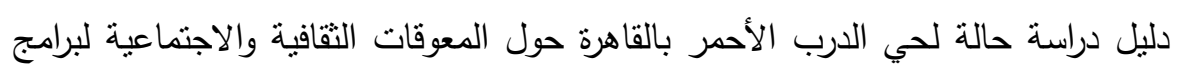

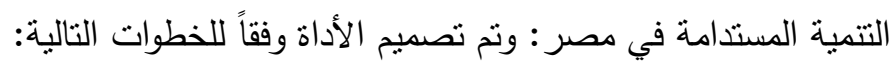

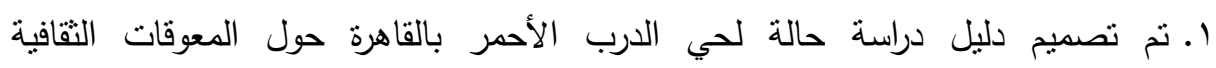

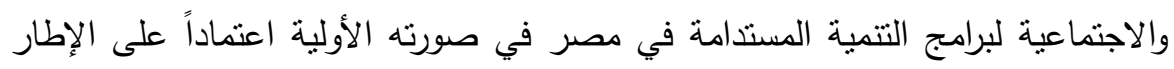

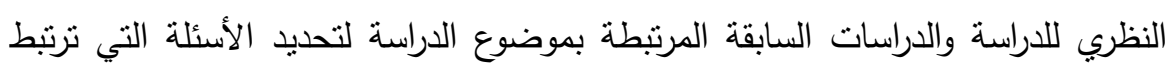

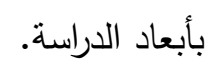
r. تم تحديد الأسئلة الدطلوبة لدليل دراسة حالة لحي الدرب الأحمر بالقاهرة، وذلك

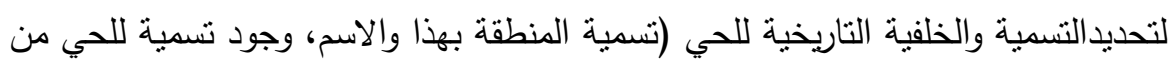

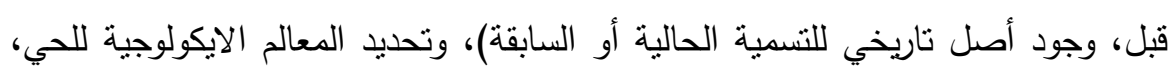

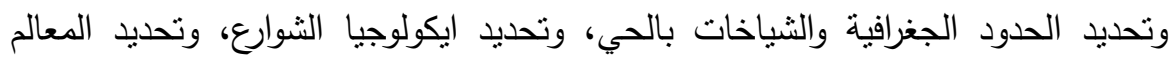

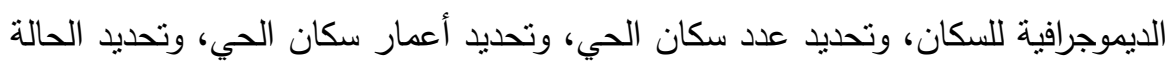

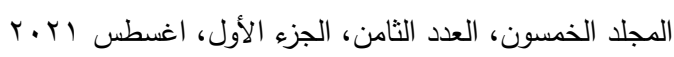

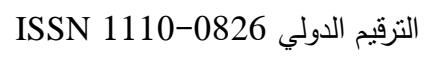

$$
\begin{aligned}
& \text { التزقيم الدولي الموحد الإلكتروني 3178-0826-2636 }
\end{aligned}
$$


التعليمية لسكان الحي، وتحديد الحالة الزواجية لسكان الحي، وتحديد الحالة المهنية لسكان الحي، وتحديد خدمات المرافق والخدمات بالحي، وتحديد الخدمات التعليمية الموجودة بالحي، وتحديد الخدمات الصحية الموجودة بالحي، وتحديد الخدمات الأمنية الموجودة

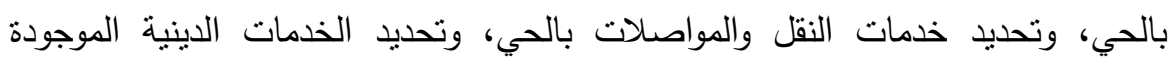

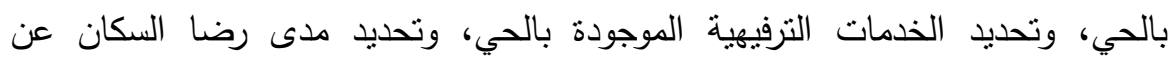
الخدمات المقدمة لهم، وتحديد طموحات السكان بالنسبة لهذه الخدمات.

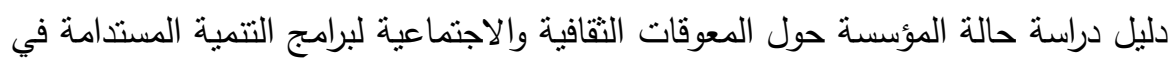
مصر : وتم تصميم الأداة وفقاً للخطوات التالية: ا ـ تم تصميم دليل دراسة حالة المؤسسة حول المعوقات الثقافية والاجتماعية لبرامج التتمية

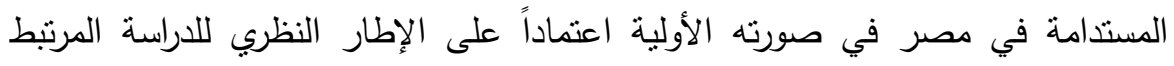
بموضوع الدراسة لتحديد الأسئلة التي نرتبط بأبعاد الدراسة. r . تم تحديد الأسئلة المطلوبة لاليل دراسة حالة المؤسسة، وذللك للتعرف على البيانات الأولية عن المؤسسة، وتحديد موقع وايكولوجيا المؤسسة، وتحديد مصادر التمويل الخاصة بتتفيذ

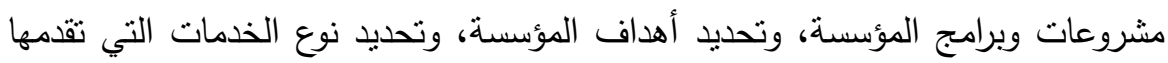
المؤسسة، وتحديد الدور الذي تلعبه المؤسسة في مجالات نتمية المجتمع، وتحديد المشروعات التي تقوم بها المؤسسة من أجل تحقيق التتمية المستدامة، وتحديد المنظومة الإدارية بالمؤسسة، وتحديد المعوقات التي تواجه المؤسسة في تقديم البرامج والخدمات التي توني

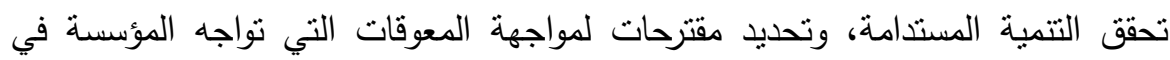
تقديم البرامج والخدمات التي تحقق التتمية المستدامة. أساليب التحليل الكيفي والكمي: اعتمد الدراسة في تحليل البيانات على الأساليب التالية: أسلوب التحليل الكيفي: بما يتتاسب وطبيعة موضوع الدراسة. 


$$
\begin{aligned}
& \text { مجلة العلوم البيئية } \\
& \text { كلية الدراسات العليا والبحوث البيئية - جامعة عين شمس لئه } \\
& \text { نجلاء حسن الخولي وآخرون }
\end{aligned}
$$

أسلوب التحليل الكمي: نم معالجة البيانات من خلال الحاسب الآلي باستخدام برنامج (SPSS .V. 24.0)

1 ا التكرارات والنسب المئوية: وذللك لوصف خصائص أفراد عينة الدراسة.

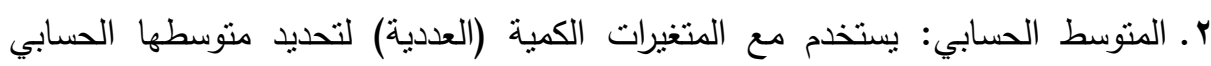
(القيمة التي تتجمع حولها قيم مجموعة ويمكن من خلالها الحكم على بقية قيم المجموعة). r. الانحراف المعياري: ويفيد في معرفة مدى نتتت أو عدم تشتت البيانات حول متوسطها

$$
\text { الحسابي. }
$$

ع. معامل ارتباط بيرسون R: وذلك لاختبار العلاقة بين متغيرين كميين،وإيجاد المصفوفة

$$
\text { الارتباطية بين متغيرات الدراسة. }
$$

$$
\text { هـ معامل ثبات (ألفا ـ كرونباخ): لقيم الثبات الثقديرية لأدوات الدراسة. }
$$

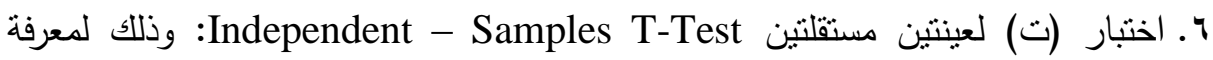
الفروق ودلالتها الإحصائية بين المبحوثين، وذلك في المتغيرات التي تقسم المبحوثين إلي مجموعتين فقط متل: استجابات المستفيدين طبقاً للجمعيات الأهلية (مؤسسة مظلة للتتمية

$$
\text { الاجتماعية/ جمعية وسط لتتمية المجتمع المحلى). }
$$

V. الرسوم البيانية: وذلك لوصف استجابات المبحوثين في أنثكال بياني.

$$
\begin{aligned}
& \text { المجلد الخمسون، العدد الثامن، الجزء الأول، اغسطس ا Y.r. }
\end{aligned}
$$

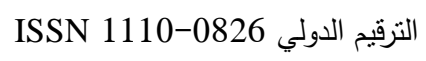

$$
\begin{aligned}
& \text { الترقيم الدولي الموحد الإكتروني 3178-2636 }
\end{aligned}
$$




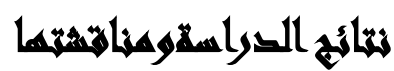

\section{برامج التنمية المستدامة التي تقدمها الجمعيات الأهلية:}

1-البرامج الاقتصادية:

جدول (•): يوضح برامج التتمية الاقتصادية التي تقدما الجمعيات الأهلية بمحافظة القاهرة كما يحددها المستقيدون (ن= • (1)

\begin{tabular}{|c|c|c|c|c|c|c|c|c|c|c|}
\hline \multirow{3}{*}{ الترتيب } & \multirow{3}{*}{ الالحرياف } & \multirow{3}{*}{ الحسابي } & \multicolumn{6}{|c|}{ الاستجابات } & \multirow{3}{*}{ العبارات } & \multirow{3}{*}{ م } \\
\hline & & & \multicolumn{2}{|c|}{$\gamma$} & \multicolumn{2}{|c|}{ إلى حا } & \multicolumn{2}{|c|}{ نعم } & & \\
\hline & & & $\%$ & ك & $\%$ & S & $\%$ & ك5 & & \\
\hline 1 & 政 & $r, q 4$ & 1,1 & r & $r, \tau$ & $\varepsilon$ & $9 \leqslant, 0$ & $1 . \varepsilon$ & تعليم الحرف & 1 \\
\hline r & $\cdot, 0 \mathrm{~V}$ & $r, \Lambda$ & $\Lambda, r$ & 9 & $r, \tau$ & $\varepsilon$ & $\Lambda \Lambda, r$ & $9 V$ & توفير فرص & r \\
\hline$r$ & $\cdot, \varepsilon)$ & 1,11 & $9 r, V$ & $1 \cdot r$ & $r, \tau$ & $\varepsilon$ & $r, 7$ & $\varepsilon$ & تقلتمبيم القروض & $r$ \\
\hline متستوى & $\cdot, Y \wedge$ & $r, Y \wedge$ & & & & & ككل & & & \\
\hline
\end{tabular}

البرامج الاقتصادية التي تقدما الجمعيات الأهلية بمحافظة القاهرة كما يحددها المستفيدون

$$
\text { تمنلت فيما يلي: }
$$

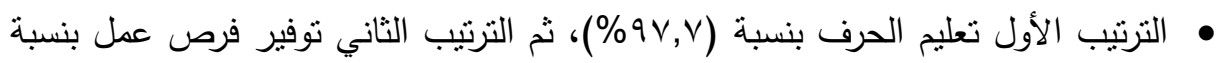

(r,r\%\%)، وأخيراً الترتيب الثالث نقديم القروض لتمويل المشروعات الصغيرة بنسبة

$$
\text { (\%rv) }
$$

• وبالنظر للجدول نجد أن نتائجه تثبر إلى أن المتوسط العام لبرامج التتمية الاقتصادية

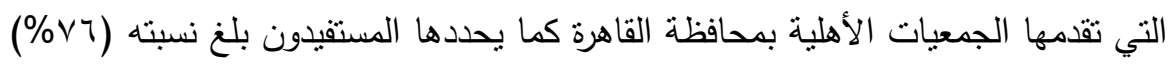
وهو مستوى متوسط. 

جدول (؟): يوضح البرامج التعليمية التي تقدمها الجمعيات الأهلية بمحافظة القاهرة كما يحددها المستقيدون (ن=-11) : (1)

\begin{tabular}{|c|c|c|c|c|c|c|c|c|c|c|}
\hline \multirow{3}{*}{ الترتيب } & \multirow{3}{*}{ المعياري } & \multirow{3}{*}{ الحسابي } & \multicolumn{6}{|c|}{ الاستجابات } & \multirow{3}{*}{ العبارات } & \multirow{3}{*}{ p } \\
\hline & & & \multicolumn{2}{|c|}{$\gamma$} & \multicolumn{2}{|c|}{ إلى حـ } & \multicolumn{2}{|c|}{ نعم } & & \\
\hline & & & $\%$ & S & $\%$ & S & $\%$ & 5 & & \\
\hline$\varepsilon$ & • rV & $1, .0$ & 90,0 & 1.0 & $r, \tau$ & $\varepsilon$ & $\cdot, 9$ & 1 & فئول محتو أكبار & 1 \\
\hline$r$ & 㱠, & $1,1 \pi$ & $9 \cdot, 9$ & $1 .$. & 0,0 & 7 & $r, \uparrow$ & $\varepsilon$ & وعنينة للحد من منالية & r \\
\hline$r$ & $\cdot, 9 \wedge$ & $r, \cdot T$ & $\varepsilon \varepsilon, 0$ & $\varepsilon 9$ & $\varepsilon, 0$ & 0 & $0 ., 9$ & 07 & 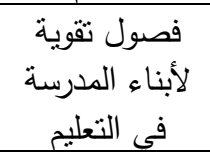 & $r$ \\
\hline 1 & $\cdot, 9 \lambda$ & $r, 10$ & $\varepsilon \cdot, q$ & \&o & $r, \tau$ & $\varepsilon$ & 00,0 & 71 & من خلال دور & $\varepsilon$ \\
\hline منخفضوى & •, Or & 1,7 & & & & & . & & & \\
\hline
\end{tabular}

البرامج التعليمية التي تقدمها الجمعيات الأهلية بمحافظة القاهرة كما يحددها المستفيدون تنتلت فيما يلي:

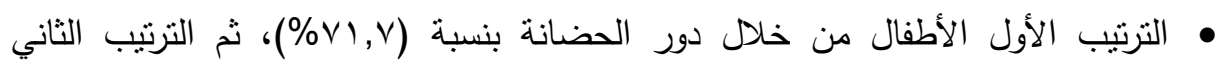

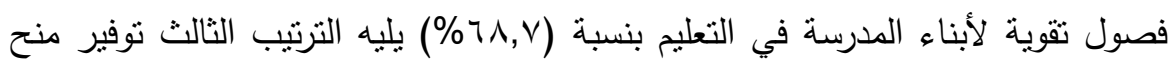

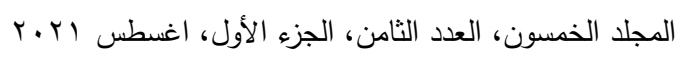

$$
\begin{aligned}
& \text { التزقيم الدولي 0826- ISSN 1110 } \\
& \text { الترقيم الدولي الموحد الإلكتروني 3178-2636 }
\end{aligned}
$$


مالية وعينية للحد من التسرب من التعليم بنسبة (\%rv,v)، وأخيراً في الترتيب الرابع

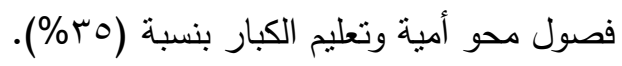
• وبالنظر للجدول نجد أن نتائجه تتبر إلى أن المتوسط العام للبرامج التعليمية التي تقدمها

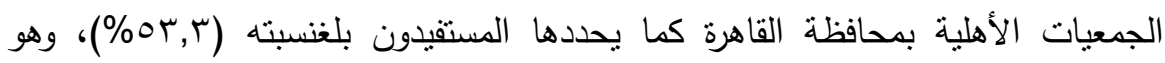
مستوى منخفض.

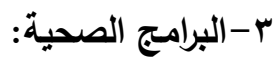
جدول (V): يوضح البرامج الصحية التي تقدمها الجمعيات الأهلية بمحافظة القاهرة كما يحددها المستفيدون (ن=•• (1)

\begin{tabular}{|c|c|c|c|c|c|c|c|c|c|c|}
\hline \multirow{3}{*}{ الترتيب } & \multirow{3}{*}{ المعياري } & \multirow{3}{*}{ الحستبي } & \multicolumn{6}{|c|}{ الاستجابات } & \multirow{3}{*}{ العبارات } & \multirow{3}{*}{ p } \\
\hline & & & \multicolumn{2}{|c|}{$y$} & \multicolumn{2}{|c|}{ إلى حد ما } & \multicolumn{2}{|c|}{ نعم } & & \\
\hline & & & $\%$ & ك5 & $\%$ & S & $\%$ & ك & & \\
\hline 1 & $\cdot, 0$ & $r, 10$ & $7, \varepsilon$ & V & 1,1 & $r$ & 91,1 & 1.1 & التوعية الصحيم برامجة & 1 \\
\hline$\varepsilon$ & $\cdot, 91$ & $r, 1$ & $\varepsilon r, V$ & $\leqslant V$ & $\varepsilon, 0$ & 0 & Or,V & 01 & قوافل طبية لحملة & r \\
\hline$r$ & $\cdot, 91$ & $r, I r$ & $\varepsilon r, V$ & $\varepsilon V$ & $r, r$ & $r$ & $0 \leqslant, 0$ & 7. & 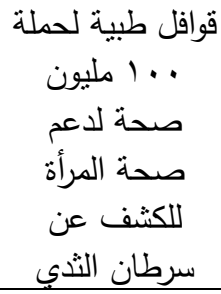 & $r$ \\
\hline r & $\cdot, 10$ & $r, \leqslant 0$ & Tr,T & YT & $V, r$ & 1 & 79,1 & $V_{7}$ & ندوات للتوعية & $\varepsilon$ \\
\hline مرتفوى & $\cdot, 70$ & r, r & & & & & & & & \\
\hline
\end{tabular}




$$
\begin{aligned}
& \text { مجلة العلوم البيئية } \\
& \text { كلية الدراسات العليا والبحوث البيئة - جامعة عين شمس لإنية } \\
& \text { نجلاء حسن الخولي وآخرون }
\end{aligned}
$$

البرامج الصحية التي تقدمها الجمعيات الأهلية بمحافظة القاهرة كما يحددها المستقيدون تمثلت فيما يلى: • التزتيب الأول تقديم برامج التوعية الصحية بنسبة (90\%)، ثم الترتيب الثاني ندوات

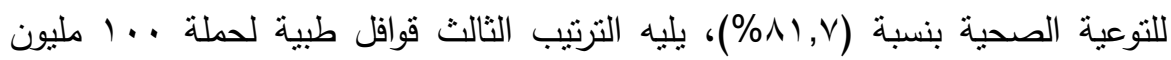

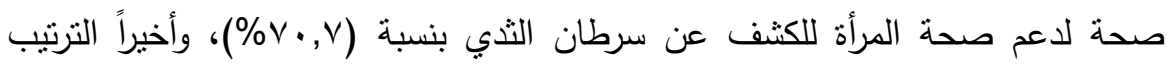

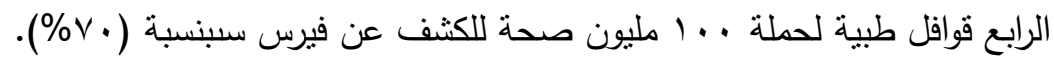
• وبالنظر للجدول نجد أن نتائجه نتشير إلي أن المتوسط العام للبرامج الصحية التي تقدمها فئس

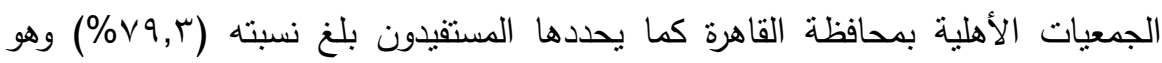
مستوى مرتفع.

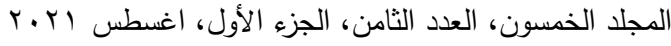

$$
\begin{aligned}
& \text { التزقيم الدولي 0826- ISSN 1110 } \\
& \text { الترقيم الدولي الموحد الإلكتروني 3178-2636 }
\end{aligned}
$$




\section{ع -برامج حماية وتنمية البيئة:}

جدول (^): يوضح برامج حماية وتتمية البيئة التي تقدمها الجمعيات الأهلية بمحافظة القاهرة كما يحددها المستقيدون (ن=.•

\begin{tabular}{|c|c|c|c|c|c|c|c|c|c|c|}
\hline \multirow{3}{*}{ الترتيب } & \multirow{3}{*}{ الالمعياري } & \multirow{3}{*}{ الحستبي } & \multicolumn{6}{|c|}{ الاستجابات } & \multirow{3}{*}{ العبارات } & \multirow{3}{*}{ p } \\
\hline & & & \multicolumn{2}{|c|}{$\gamma$} & \multicolumn{2}{|c|}{ إلى حـ } & \multicolumn{2}{|c|}{ نعم } & & \\
\hline & & & $\%$ & ك & $\%$ & ك5 & $\%$ & ك5 & & \\
\hline r & • & T,Mr & $r, \Lambda$ & ro & $\varepsilon, 0$ & 0 & ד, & $v$. & البيئة السلبمة التوعية & 1 \\
\hline$\varepsilon$ & •, rV & $1, .9$ & $9 \pi, 7$ & $1 . r$ & $r, \uparrow$ & $\varepsilon$ & $r, V$ & $r$ & تنفيذ مشروعات & $r$ \\
\hline$r$ & $\cdot, 0 \leqslant$ & $1,1 \mathrm{~V}$ & 9. & 99 & $r, V$ & $r$ & $V, r$ & $\wedge$ & تتفيذ مشروع جمع القمامة & $r$ \\
\hline 1 & $\cdot, \wedge 9$ & $r, \varepsilon r$ & $r V, r$ & $r$. & $r, \uparrow$ & $\varepsilon$ & 79,1 & V & 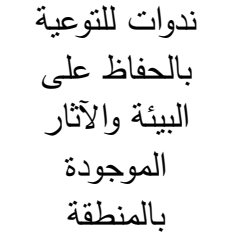 & $\varepsilon$ \\
\hline منتوسط & •, I I & $1, \times 0$ & & & & & ككل & & & \\
\hline
\end{tabular}

برامج حماية وتتمية البيئة التي تقدمها الجمعيات الأهلية بمحافظة القاهرة كما بحددها المستقيدون تمثلت فيما يلى: بلى وبنه

• الترتيب الأول ندوات للتوعية بالحفاظ على البيئة والآثار الموجودة بالمنطقة بنسبة

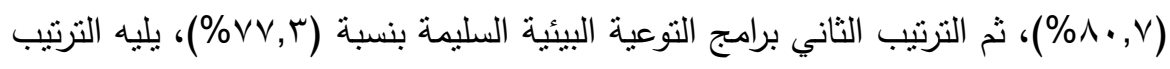

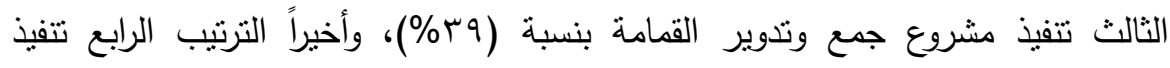

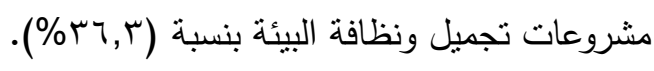

98

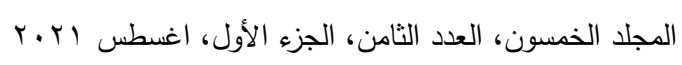

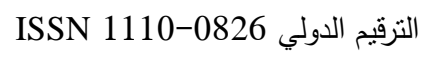

الترقيم الدولي الموحد الإكتروني 3178-2636 
• وبالنظر للجدول نجد أن نتائجه نتشير إلي أن المتوسط العام لبرامج حماية وتتمية البيئة

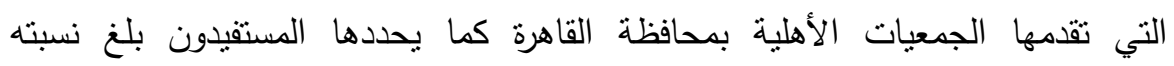

$$
\begin{aligned}
& \text { ه (\%०८,r) وهو مستوى منوسط. } \\
& \text { ه-برامج التوعية المجتمعية: }
\end{aligned}
$$

جدول (^): يوضح برامج التوعية المجتمعية التي تقدمها الجمعيات الأهلية بمحافظة القاهرة

\begin{tabular}{|c|c|c|c|c|c|c|c|c|c|c|}
\hline \multirow{3}{*}{ الترتيب } & \multirow{3}{*}{ الالانحراف } & \multirow{3}{*}{ الحسابي } & \multicolumn{6}{|c|}{ الاستجابات } & \multirow{3}{*}{ العبارات } & \\
\hline & & & \multicolumn{2}{|c|}{$\gamma$} & \multicolumn{2}{|c|}{ إلى حـ } & \multicolumn{2}{|c|}{ نعم } & & s \\
\hline & & & $\%$ & ك & $\%$ & ك & $\%$ & ك & & \\
\hline$r$ & •,AY & $1, \leqslant 0$ & $V\urcorner, \varepsilon$ & $\Lambda \varepsilon$ & $r, V$ & $r$ & $r \cdot, q$ & $r r$ & 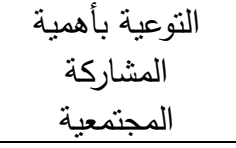 & 1 \\
\hline$r$ & $\cdot$, Or & $1,1 \mathrm{~V}$ & $\wedge 9,1$ & 91 & $\varepsilon, 0$ & 0 & ૫, ₹ & V & القانونية بلألحقوق & r \\
\hline$\varepsilon$ & $\cdot, \leqslant 9$ & 1,10 & 9. & 99 & $\varepsilon, 0$ & 0 & 0,0 & 7 & المشاركة السياسية بأهمية & $r$ \\
\hline 1 & $\cdot, 97$ & Y, YO & rา, & $\varepsilon$. & $r, v$ & $r$ & $7 \cdot, 9$ & TV & التوعية الدينية & $\varepsilon$ \\
\hline منخفضوى & • & 1,0 & & & & & & & & \\
\hline
\end{tabular}
كما يحددها المستقيدون (ن= • (11)

برامج التوعية المجتمعية التي تقدمها الجمعيات الأهلية بمحافظة القاهرة كما يحددها المستقبدون تمثلت فيما يلى: • الترتيب الأول التوعية الدينية للأفراد بنسبة (\%०\%)، ثم الترتيب الثاني التوعية بأهية

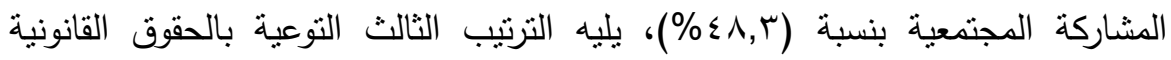

$$
\begin{aligned}
& \text { المجلد الخمسون، العدد الثامن، الجزء الأول، اغسطس I.Y.T } \\
& \text { التزقيم الدولي 0826- ISSN 1110 } \\
& \text { الترقيم الدولي الموحد الإلكتروني 3178-2636 }
\end{aligned}
$$


للأفراد بنسبة (9 (r)، وأخيراً الترتيب الرابع التوعية بأهمية المشاركة السياسية للأفراد بنسبة

• وبالنظر للجدول نجد أن نتائجه نتشير إلي أن المتوسط العام لبرامج التوعية المجتمعية التي

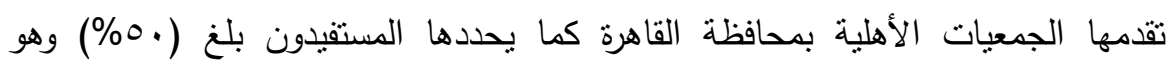

$$
\text { مستوى منخفض. }
$$

\section{צ-برامج التنمية الثقافية والأدبية:}

جدول (9): يوضح برامج التتمية الثقافية والأدبية التي تقدمها الجمعيات الأهلية بمحافظة القاهرة كما يحددها المستفيدون (ن= • (1)

\begin{tabular}{|c|c|c|c|c|c|c|c|c|c|c|}
\hline \multirow{3}{*}{ 售: } & \multirow{3}{*}{$\underline{E}$} & \multirow{3}{*}{$\underline{E}$} & \multicolumn{6}{|c|}{ الاستجابات } & \multirow{3}{*}{ العبارات } & \multirow{3}{*}{ p } \\
\hline & & & \multicolumn{2}{|c|}{$\gamma$} & \multicolumn{2}{|c|}{ إلى حـ } & \multicolumn{2}{|c|}{ نعم } & & \\
\hline & & & $\%$ & ك5 & $\%$ & كs & $\%$ & S & & \\
\hline r & $\cdot, V Y$ & T,TV & $1 \leqslant, 0$ & 17 & $r, \tau$ & $\varepsilon$ & $\wedge 1, \wedge$ & 9. & الموافوبين والنابغين فية المياف ورعاية & 1 \\
\hline 1 & $\cdot, 01$ & $r, V \wedge$ & $\Lambda, r$ & 9 & 0,0 & 7 & $\wedge \uparrow, \varepsilon$ & 90 & نداريخ منطقة الدربية للتوعية & $r$ \\
\hline 0 & $\cdot, \wedge \Gamma$ & $1, \sum V$ & $V \leqslant, 0$ & $\Lambda T$ & $r, \tau$ & $\varepsilon$ & $r, 1, \Lambda$ & $r \varepsilon$ & دعم أنشطة المكتبات & $r$ \\
\hline r & $\cdot, \mathrm{V}_{0}$ & $Y, T \leq$ & $17, \varepsilon$ & 11 & $r, 7$ & $\varepsilon$ & A. & $\Lambda \Lambda$ & إقامة المسابقات الثقافية & $\varepsilon$ \\
\hline$\varepsilon$ & $\cdot, \wedge \leq$ & $r, 0$ & $r, V$ & ro & $\varepsilon, 0$ & 0 & $V Y, V$ & A. & دروس لحفظ وتجويد & 0 \\
\hline مرتفوى & $\cdot, r q$ & $r, \varepsilon 1$ & & & & & & 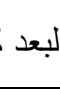 & & \\
\hline
\end{tabular}


برامج التتمية التقافية والأدبية التي تقدمها الجمعيات الأهلية بمحافظة القاهرة كما يحددها المستقيدون تمنلات فيما يلى: بلى

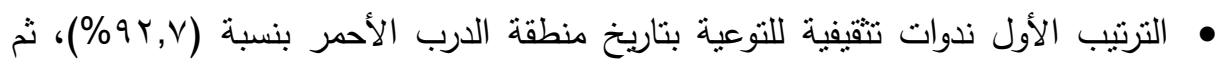
الترتيب الثاني اكتثاف ورعاية الموهوبين والنابغين في كافة المجالات الثقافية والعلمية والفكرية والفنية بنسبة (9>\%)، يليه الترتيب الثالث إقامة المسابقات الثقافية بنسبة

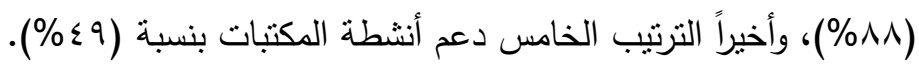
• وبالنظر للجدول نجد أن نتائجه تشير إلي أن المتوسط العام لبرامج التتمية الثقافية والأدبية

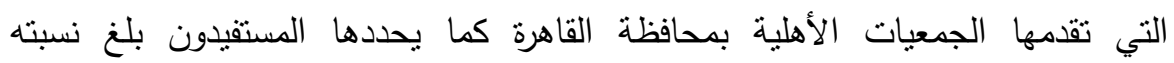

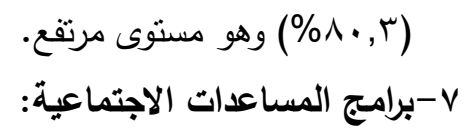
جدول (• (1): يوضح برامج المساعدات الاجتماعية التي تقدها الجمعيات الأهلية بمحافظة

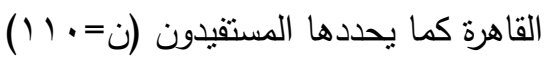

\begin{tabular}{|c|c|c|c|c|c|c|c|c|c|c|}
\hline \multirow{3}{*}{ 覧 } & \multirow{3}{*}{$\underline{\underline{E}}$} & \multirow{3}{*}{$E$} & \multicolumn{6}{|c|}{ الاستجابات } & \multirow{3}{*}{ العبارات } & \multirow{3}{*}{ م } \\
\hline & & & \multicolumn{2}{|c|}{$y$} & \multicolumn{2}{|c|}{ إلى حد ما } & \multicolumn{2}{|c|}{ نعم } & & \\
\hline & & & $\%$ & ك & $\%$ & S & $\%$ & ك & & \\
\hline 1 & $\cdot, \mathrm{\vee} \wedge$ & $\mathrm{r}, \mathrm{OV}$ & $1 \Lambda, r$ & r. & $7, \varepsilon$ & V & Vo,o & NT & تقديم برامج رعاية & 1 \\
\hline r & $\cdot, 9 \vee$ & $r, 19$ & $r q, 1$ & $\varepsilon r$ & $Y, V$ & $r$ & $O \Lambda, Y$ & $7 \varepsilon$ & 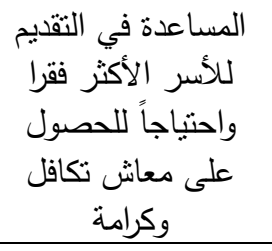 & r \\
\hline$\varepsilon$ & $\cdot, 7$ & $1, Y \varepsilon$ & 10,0 & $9 \leqslant$ & 0,0 & 7 & 9,1 & 1. & رعاية الطلاب & $r$ \\
\hline$r$ & $\cdot, 0 \leqslant$ & $1, r v$ & 70,0 & $V Y$ & $\Gamma, 1$ & ro & $r, V$ & r & توفير أجهزة تعويضية & $\varepsilon$ \\
\hline
\end{tabular}

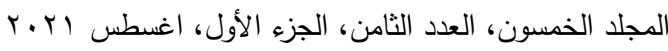

التزقيم الدولي 0826-0 العدون

الترقيم الدولي الموحد الإلكتروني 3178-2636 
مجلة العلوم البيئية

كلية الدراسات العليا والبحوث البيئية - جامعة عين شمس لفئة

نجلاء حسن الخولي وآخرون

\begin{tabular}{|c|c|c|c|c|c|c|c|c|c|c|}
\hline \multirow{3}{*}{ 熙 } & \multirow{3}{*}{$\underline{E}$} & \multirow{3}{*}{$E$} & \multicolumn{6}{|c|}{ الاستجابات } & \multirow{3}{*}{ العبارات } & \\
\hline & & & \multicolumn{2}{|c|}{$y$} & \multicolumn{2}{|c|}{ إلى حد ما } & \multicolumn{2}{|c|}{ نعم } & & p \\
\hline & & & $\%$ & ك & $\%$ & ك5 & $\%$ & ك5 & & \\
\hline & & & & & & & & & الخاصة & \\
\hline منوستوى & •, ro & $1, \wedge \varepsilon$ & \multicolumn{7}{|c|}{ البعد ككل } & \\
\hline
\end{tabular}

برامج المساعدات الاجتماعية التي تقدمها الجمعيات الأهلية بمحافظة القاهرة كما يحددها

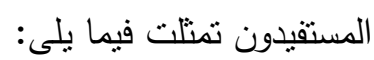

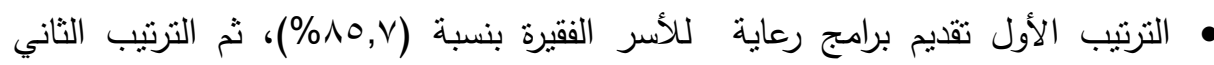

المساعدة في التقديم للأسر الأكثر فقرا واحتباجاً للحصول على رعابه معاش تكافل وكرة وكرامة بنسبة

(\%VY)

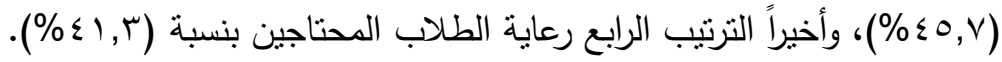

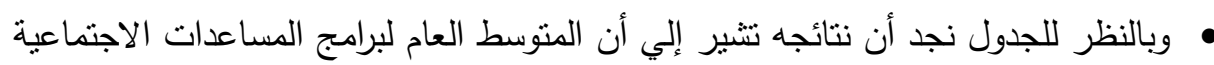

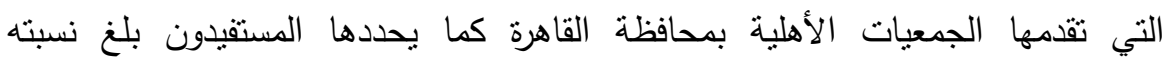

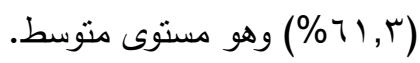

برامج التتمية المستدامة التي تقدمها الجمعيات الأهلية بمحافظة القاهرة كما يحددها

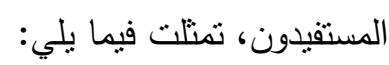

وبالنظر للجدول نجد أن نتائجه تثبر إلي أن المتوسط العام لبرامج التتمية المستدامة

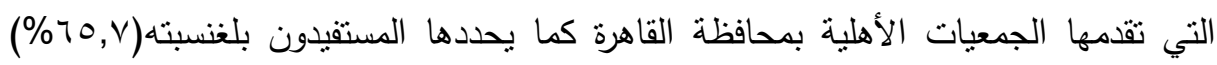
وهو مستوى متوسط. ومن خلال عرض نتائج الدراسة المتعلقة بمحور التتمبة المستدامة يحدد الباحثون أوجه الاتفاق والاختلاف والاستفادة من الدراسات السابقة لمحور التتمية المستدامة كالآتى: 


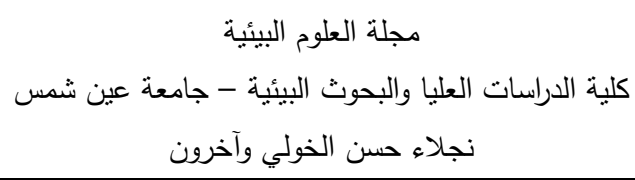

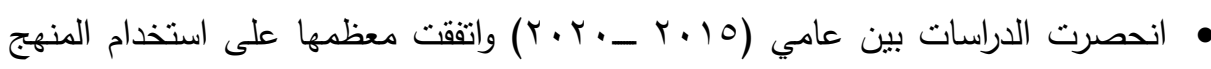
الوصفي. • استخدمت بعض الدرسات أسلوب الملاحظه الموضوعية واستمارة جمع البيانات وتضمنت وسائل جمع البيانات ما يلي: (الملاحظة العلمية ـ استمارة تسجيل البيانات ـ استمارة استنيان ـ المقابلة الثخصية) واختلفت المعالجات الإحصائية للاراسات طبقا لاختلاف الأهداف لكل دراسة.

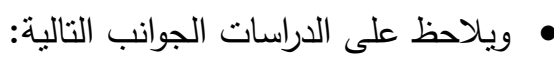

اــ ركزت الدراسات جميعها على كيفية تحقيق أهداف التتمية المستدامة كل في مجاله، وكيفية تطوير استراتيجية العمل.

r. أغلت الدراسات حتمية التأثير المتبادل بين كافة الجوانب الاجتماعيه والنفسية والصحية والاجتماعيه والاقتصاديه كأحد ركائز منظومة التتمية المستدامة.

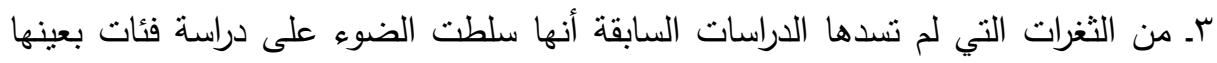
في حين قامت بتعميم النتائج وهو ما قد يؤنث سلبا علي روئية التتمية المستدامه لإغفال فئات أخرى لم يتم الانتباه لها. • إنمكن الاستفاده من الدراسات السابقة في الأوجه التالية:

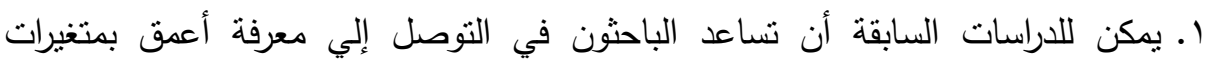
دراستها كما يمكنها أن توجه الباحثة إلى اختيار أنسب وسيلة لجمع وتحليل البيل البيانات.

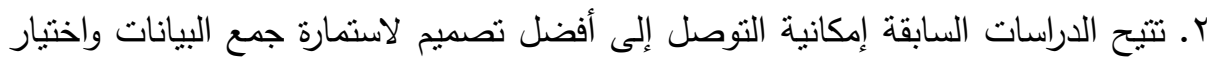
التحليل الإحصائي الأنسب للإراسة. r. كثفت الدراسات السابقة عن وجود ثغرات بحثية جديدة لم تتتاولها تلك الدراسات مما يوجه نظر الباحثون نحو سد نلاك الثغرات، ويسهم بالتالي في التوصل لنتائج بحثية جديدة غير لنران 
مجلة العلوم البيئية - مالية

كلية الدراسات العليا والبحوث البيئية - جامعة عين شس البئ

نجلاء حسن الخولي وآخرون

أنساق القيم السائدة في المجتمع ومدى تأثيرها على برامج التنمية المستدامة:

1-القيم الاقتصادية:

جدول (11): يوضح القيم الاقتصادية السائدة في المجتمع ومدى تأثيرها على برامج التتمية

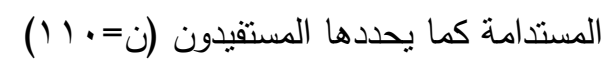

\begin{tabular}{|c|c|c|c|c|c|c|c|c|c|c|}
\hline \multirow{3}{*}{ الترتيب } & \multirow{3}{*}{ الاتحراف } & \multirow{3}{*}{ المستوسط } & \multicolumn{6}{|c|}{ الاستجابات } & \multirow{3}{*}{ العبارات } & \multirow{3}{*}{ e } \\
\hline & & & \multicolumn{2}{|c|}{$y$} & \multicolumn{2}{|c|}{ إلى حـ ما } & \multicolumn{2}{|c|}{ نعر } & & \\
\hline & & & $\%$ & ك & $\%$ & ك & $\%$ & ك & & \\
\hline r & • & r,q & 1,1 & r & $r, \uparrow$ & $\varepsilon$ & $9 \leqslant, 0$ & $1 \cdot \varepsilon$ & المنتج والمثمر & 1 \\
\hline$\varepsilon$ & $\cdot, \Gamma \leq$ & $r, \wedge q$ & $\cdot, 9$ & 1 & 9,1 & 1. & 9. & 99 & $\begin{array}{c}\text { أحرص العاء الحقوق } \\
\text { العالية لأصحابها }\end{array}$ & r \\
\hline$\wedge$ & $\cdot, 0$ & r, Tr & $\cdot, 9$ & 1 & $r_{0,0}$ & rq & ד, & $v$. & نرشيد الاستهلالى ألى المرارد & $r$ \\
\hline 1 & $\cdot, Y 4$ & r,qr & - & - & $v, r$ & $\wedge$ & $q r, V$ & $1 \cdot r$ & والحافظكات على البيئة & $\varepsilon$ \\
\hline$r$ & $\cdot, r q$ & $r, 91$ & - & - & 9,1 & 1. & $9 \cdot, 9$ & $1 \ldots$ & تشجيع المنتجات على أحرصنية & 0 \\
\hline v & $\cdot, \sum \wedge$ & T,T & - & - & ץч, £ & $\varepsilon$. & ד,זד & $v$. & تبطربقة لاحنقاجة أموالىة & 7 \\
\hline 1 & $\cdot, \varepsilon 1$ & $r, V \wedge$ & - & - & $r, \Lambda$ & $r \varepsilon$ & $\vee \wedge, r$ & $\Lambda T$ & 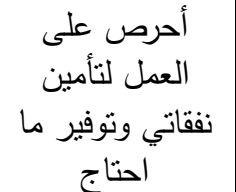 & V \\
\hline
\end{tabular}

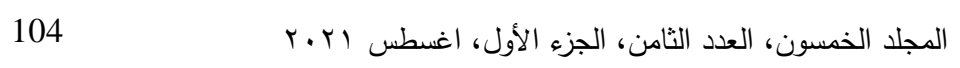

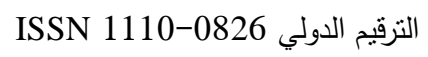

التزقيم الدولي الموحد الإلكتروني 3178-2636 
مجلة العلوم البيئية

كلية الدراسات العليا والبحوث البيئية - جامعة عين شمس البئة

نجلاء حسن الخولي وآخرون

\begin{tabular}{|c|c|c|c|c|c|c|c|c|c|c|}
\hline \multirow{3}{*}{ الترتيب } & \multirow{3}{*}{ المعياري } & \multirow{3}{*}{ الحسابي } & \multicolumn{6}{|c|}{ الاستجابات } & \multirow{3}{*}{ العبارات } & \multirow{3}{*}{ م } \\
\hline & & & \multicolumn{2}{|c|}{$y$} & \multicolumn{2}{|c|}{ إلى حد ما } & \multicolumn{2}{|c|}{ نعم } & & \\
\hline & & & $\%$ & ك & $\%$ & ك5 & $\%$ & ك5 & & \\
\hline 0 & תז, & T,AV & - & - & $\mid r, v$ & $1 \varepsilon$ & $\lambda \vee, r$ & 97 & أعمالي والقيام بها & $\wedge$ \\
\hline مرتفع مستو & $\cdot, 19$ & $r, A Y$ & \multicolumn{8}{|c|}{ البعد ككل } \\
\hline
\end{tabular}

القيم الاقتصادية السائدة في المجتمع ومدى تأثيرها على برامج التتمية المستدامة كما يحددها المستفيدون تمنلت فيما يلى :

هالترتيب الأول أحافظ على البيئة والممنلكات العامة واحترم العمل المنتج والمثمر بنسبة

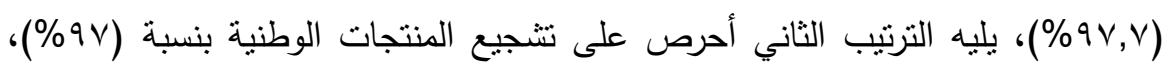

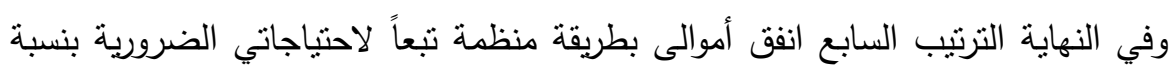

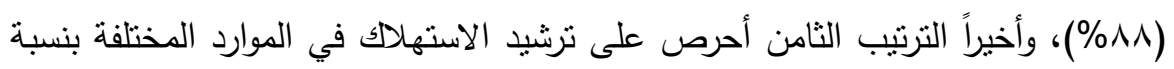

$$
\cdot(\% \wedge \vee, \vee)
$$

وبالنظر للجدول نجد أن نتائجه نتشير إلي أن المنوسط العام للقيم الاقتصادية السائدة في

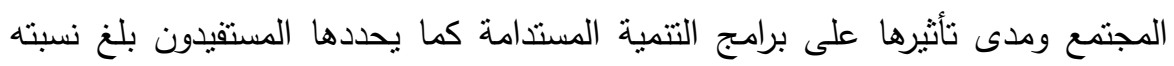

$$
\text { ( }
$$

\footnotetext{
المجلد الخمسون، العدد الثامن، الجزء الأول، اغسطس ابr.r.

التزقيم الدولي 0826- ISSN 1110

الترقيم الدولي الموحد الإلكتروني 3178-2636
} 


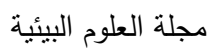

كلية الدراسات العليا والبحوث البيئية - جامعة عين شمس لفئة

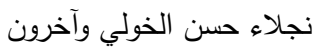

r - القيم الاجتماعية:

جدول (Y Y): يوضح القيم الاجتماعية السائدة في المجتمع ومدى تأثثرها على برامج التتمية المستدامة كما يحددها المستقيدون (ن= •11) (1)

\begin{tabular}{|c|c|c|c|c|c|c|c|c|c|c|}
\hline \multirow{3}{*}{ الترتيب } & \multirow{3}{*}{ الالانحراف } & \multirow{3}{*}{ الحسابي } & \multicolumn{6}{|c|}{ الاستجابات } & \multirow{3}{*}{ العبارات } & \multirow{3}{*}{ r } \\
\hline & & & \multicolumn{2}{|c|}{$y$} & \multicolumn{2}{|c|}{ إلى حد ما } & \multicolumn{2}{|c|}{ نعم } & & \\
\hline & & & $\%$ & ك5 & $\%$ & ك & $\%$ & ك5 & & \\
\hline 1 & . & $r$ & - & - & - & - & $1 \ldots$ & 11. & أعامل جيراني & 1 \\
\hline r & $\cdot, 1$ & ५, १९ & - & - & $\cdot, 9$ & 1 & 99,1 & 1.9 & أنواضع في & r \\
\hline 9 & $\cdot, r V$ & $r, \wedge \varepsilon$ & - & - & $17, \varepsilon$ & 11 & $\Lambda \Gamma, \uparrow$ & 94 & استمع إلى حديث & $r$ \\
\hline V & $\cdot, r$ & $\uparrow, \wedge q$ & - & - & $1 \cdot, 9$ & ir & 19,1 & 91 & كأقول الحق مهما & $\varepsilon$ \\
\hline 1. & $\cdot, \varepsilon \Gamma$ & r, Yo & - & - & $r \leqslant, 0$ & TV & $v_{0,0}$ & Nז & أفراحهم وأحزانهم أنشاس & 0 \\
\hline 7 & $\cdot, r$ & $r, q$ & - & - & 1. & 11 & 9. & 99 & الآخرين وأناقشيه آراء & 7 \\
\hline$r$ & $\cdot, 1 T$ & $r, 91$ & - & - & $1, \Lambda$ & r & $9 \wedge, Y$ & $1 \cdot 1$ & احترم كبار السن & V \\
\hline$\wedge$ & $\cdot$ & $r, \wedge 0$ & - & - & 10,0 & iv & $\Lambda \varepsilon, 0$ & 94 & 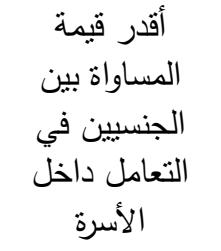 & $\wedge$ \\
\hline
\end{tabular}

106

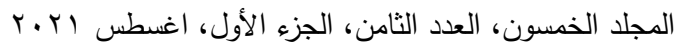

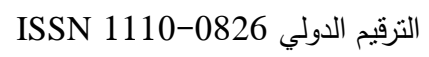

الترقيم الدولي الموحد الإلكتروني 3178-2636 
مجلة العلوم البيئية

كلية الدراسات العليا والبحوث البيئية - جامعة عين شمس البئة

نجلاء حسن الخولي وآخرون

\begin{tabular}{|c|c|c|c|c|c|c|c|c|c|c|}
\hline \multirow{3}{*}{ الترتيب } & \multirow{3}{*}{ المعياري } & \multirow{3}{*}{ الحسابي } & \multicolumn{6}{|c|}{ الاستجابات } & \multirow{3}{*}{ العبارات } & \multirow{3}{*}{ p } \\
\hline & & & \multicolumn{2}{|c|}{$\gamma$} & \multicolumn{2}{|c|}{ إلى حد ما } & \multicolumn{2}{|c|}{ نعم } & & \\
\hline & & & $\%$ & ك5 & $\%$ & ك & $\%$ & ك & & \\
\hline$\varepsilon$ & $\cdot, 19$ & r,97 & - & - & $r, \tau$ & $\varepsilon$ & $97, \S$ & 1.7 & 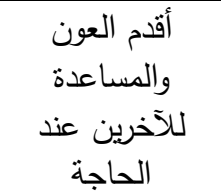 & 9 \\
\hline$\varepsilon$ & $\cdot, 19$ & Y, 97 & - & - & $r, \tau$ & $\varepsilon$ & $97, \varepsilon$ & 1.7 & ألتجنب تجريح & 1. \\
\hline 0 & $\cdot, r q$ & $r, 9)$ & - & - & 9,1 & 1. & $9 \cdot, 9$ & $1 \ldots$ & فالنفع على بما نفستي وقد & 11 \\
\hline مرتفع مستوى & •, 17 & $r, 91$ & & & & & & & & \\
\hline
\end{tabular}

القيم الاجتماعية السائدة في المجتمع ومدى ثأثيرها على برامج التتمية المستدامة كما يحددها

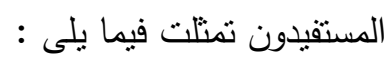

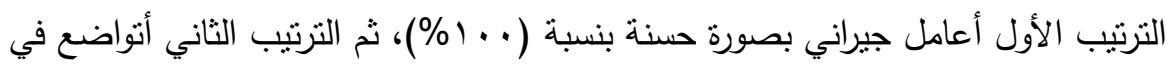

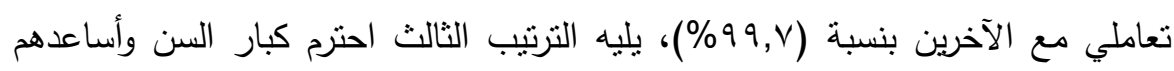

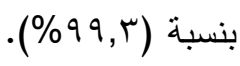

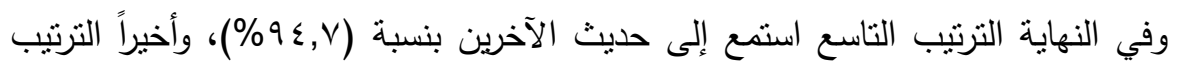

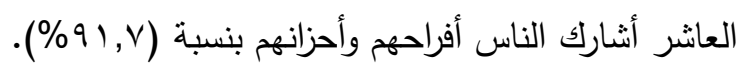

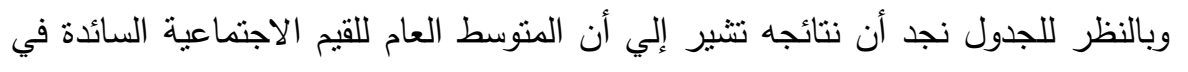

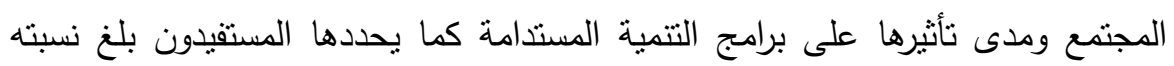

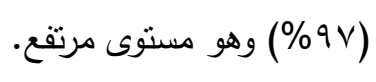

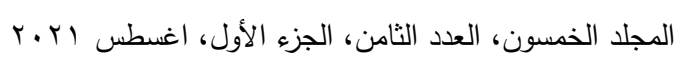

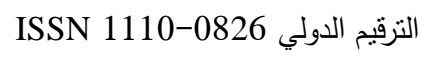

التزقيم الدولي الموحد الإلكتروني 3178-2636 التروفي 
مجلة العلوم البيئية - مالية

كلية الدراسات العليا والبحوث البيئية - جامعة عين شس البئ

نجلاء حسن الخولي وآخرون

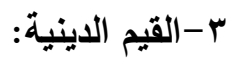

جدول (T (1): يوضح القيم الدينية السائدة في المجتمع ومدى تأثنرها على برامج التتمية

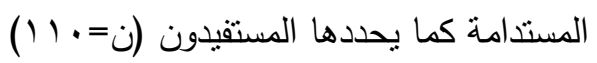

\begin{tabular}{|c|c|c|c|c|c|c|c|c|c|c|}
\hline \multirow{3}{*}{ الترتيب } & \multirow{3}{*}{ المعياري } & \multirow{3}{*}{ الحسابي } & \multicolumn{6}{|c|}{ الاستجابات } & \multirow{3}{*}{ العبارات } & \multirow{3}{*}{ p } \\
\hline & & & \multicolumn{2}{|c|}{$y$} & \multicolumn{2}{|c|}{ إلى حد ما } & \multicolumn{2}{|c|}{ نعم } & & \\
\hline & & & $\%$ & ك5 & $\%$ & S & $\%$ & ك & & \\
\hline 1 & . & $r$ & - & - & - & - & $1 \ldots$ & 11. & أحافظ على أداء & 1 \\
\hline r & $\cdot, 1$ & $r, 99$ & - & - & $\cdot, 9$ & 1 & 99,1 & 1.9 & فبحانه وتعلى ألى الله & $r$ \\
\hline 0 & $\cdot, 19$ & r,97 & - & - & $r, \tau$ & $\varepsilon$ & $97, \varepsilon$ & 1.7 & وأحرص علبى رالدي & $r$ \\
\hline v & $\cdot, r V$ & $r, \wedge \varepsilon$ & - & - & $17,\{$ & 11 & NT, & 94 & أحافظ على صلة & $\varepsilon$ \\
\hline$\varepsilon$ & $\cdot, 17$ & T, १V & - & - & $r, V$ & $r$ & $q \vee, r$ & $1 \cdot v$ & مساعدة الآخرين عرصى & 0 \\
\hline 7 & • & $r, 91$ & 1,1 & r & 0,0 & 7 & $q r, V$ & $1 . r$ & مقوق في ممارسة الآخرين على & 7 \\
\hline$r$ & •, & $r, 9 \wedge$ & - & - & 1,1 & r & $q \wedge, r$ & 1.1 & أحسب المال على في جميع أحمالي & v \\
\hline مرتفوى م مستو & $\cdot, 1 Y$ & $r, 90$ & & & & & كل كل & & & \\
\hline
\end{tabular}

108

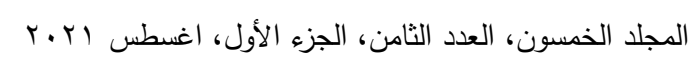

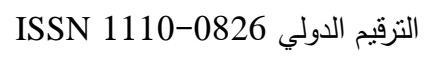

التزقيم الدولي الموحد الإلكتروني 3178-2636 الترب 
القيم الدينية السائدة في المجتمع ومدى تأثيرها على برامج التمية المستدامة كما يحددها

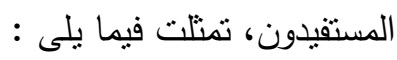

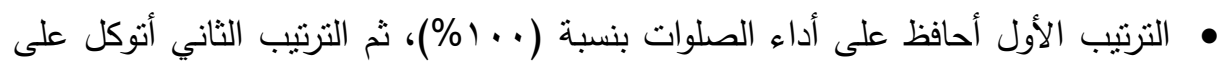

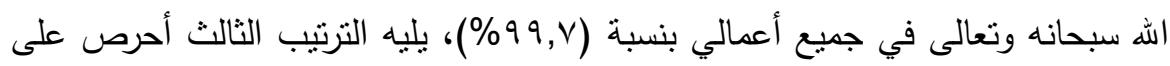

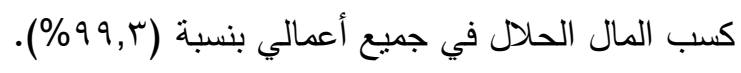

• وفي النهاية الترتيب السادس أحافظ على حقوق الآخرين في ممارسة معتقداتهم الدينية

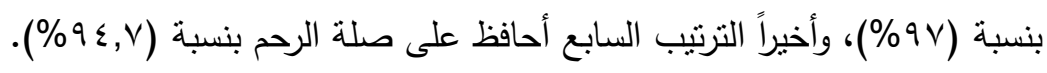

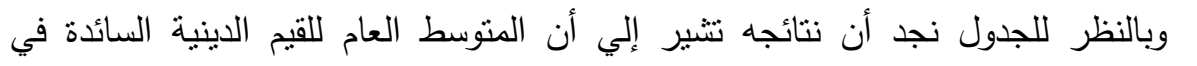

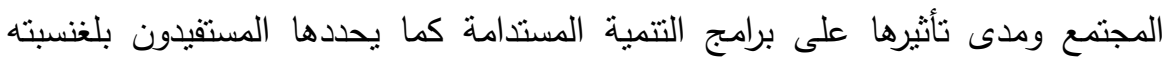

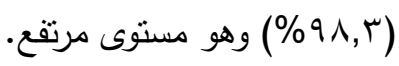

$$
\begin{aligned}
& \text { ع - القيم السياسية: }
\end{aligned}
$$

\begin{tabular}{|c|c|c|c|c|c|c|c|c|c|c|}
\hline \multirow{3}{*}{ الترتيب } & \multirow{3}{*}{ الالحعراف } & \multirow{3}{*}{ الحستبي } & \multicolumn{6}{|c|}{ الاستجابات } & \multirow{3}{*}{ العبارات } & \multirow{3}{*}{ p } \\
\hline & & & \multicolumn{2}{|c|}{$y$} & \multicolumn{2}{|c|}{ إلى حد ما } & \multicolumn{2}{|c|}{ نعم } & & \\
\hline & & & $\%$ & s & $\%$ & s & $\%$ & ك5 & & \\
\hline 1 & $\cdot, 17$ & Y, १V & - & - & $r, V$ & $r$ & $q \vee, r$ & $1 \cdot v$ & والأنظمة المعدمول القوانين & 1 \\
\hline 0 & $\cdot$, YO $_{0}$ & $r, q \varepsilon$ & - & - & $7, \varepsilon$ & V & 94,7 & $1 \cdot r$ & 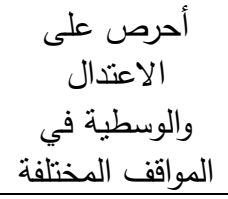 & r \\
\hline r & $\cdot, 19$ & Y,97 & - & - & $r, \tau$ & $\varepsilon$ & $97, \varepsilon$ & 1.7 & منكات أحافظ على الوطن & $r$ \\
\hline
\end{tabular}

جدول (؛ 1): يوضح القيم السياسية السائدة في المجتمع ومدى تأثثرها على برامج التتمية

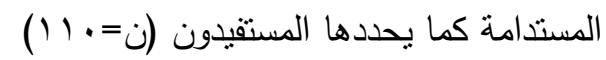

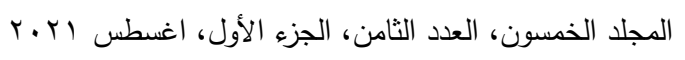

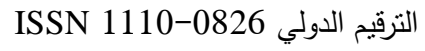

الترقيم الدولي الموحد الإلكتروني 3178-2636 
مجلة العلوم البيئية - مالية

كلية الدراسات العليا والبحوث البيئية - جامعة عين شس البئ

نجلاء حسن الخولي وآخرون

\begin{tabular}{|c|c|c|c|c|c|c|c|c|c|c|}
\hline \multirow{3}{*}{ الترتيب } & \multirow{3}{*}{ الانحراف } & \multirow{3}{*}{ الحسابي } & \multicolumn{6}{|c|}{ الاستجابات } & \multirow{3}{*}{ العبارات } & \multirow{3}{*}{ م } \\
\hline & & & \multicolumn{2}{|c|}{ y } & \multicolumn{2}{|c|}{ إلى حد ما } & \multicolumn{2}{|c|}{ نعم } & & \\
\hline & & & $\%$ & ك5 & $\%$ & ك5 & $\%$ & 5 & & \\
\hline r & $\cdot, 19$ & $r, 97$ & - & - & $r, \tau$ & $\varepsilon$ & $97, \varepsilon$ & 1.7 & أعتز بانجازات & $\varepsilon$ \\
\hline$\varepsilon$ & $\cdot, r \wedge$ & $r, 90$ & 1,1 & $r$ & $\cdot, 9$ & 1 & $9 \vee, r$ & $1 \cdot v$ & أحب وطني أحرص على عنى & 0 \\
\hline V & $\cdot, \leqslant 9$ & $r, 09$ & - & - & $\varepsilon \cdot, q$ & $\leq 0$ & 09,1 & 70 & الونابعة القضايا & 7 \\
\hline 7 & ו & r,^৭ & - & - & $1 \cdot, 9$ & Ir & $\wedge 9,1$ & 91 & فأحرص على التمية الوطنة & V \\
\hline$r$ & $\cdot, Y T$ & $r, 90$ & - & - & 0,0 & 7 & $9 \leqslant, 0$ & $1 \cdot \varepsilon$ & أحزرص ملاهيز & $\Lambda$ \\
\hline مستوى & $\cdot, 10$ & $r, q$ & & & & & & & & \\
\hline
\end{tabular}

القيم السياسية السائدة في المجتمع ومدى تأثيرها على برامج التتمية المستدامة كما يحددها المستفيدون، تمنلت فيما يلى: • الترتيب الأول احترم القوانين والأنظمة المعمول بها بنسبة (99\%)، ثم الترتيب الثاني

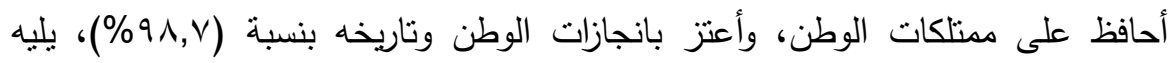

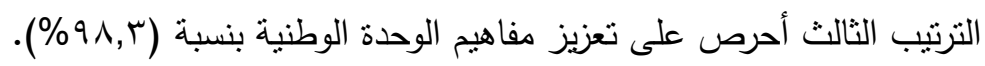

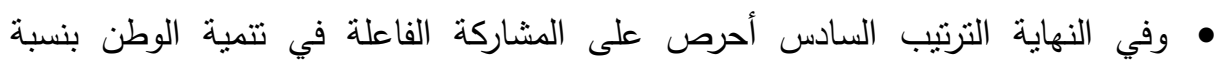

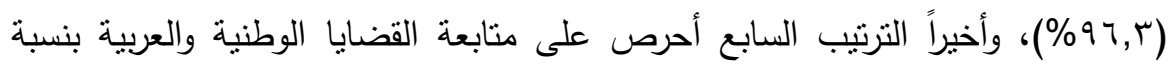


• وبالنظر للجدول نجد أن نتائجه نتشير إلي أن المتوسط العام للقيم السياسية السائدة في

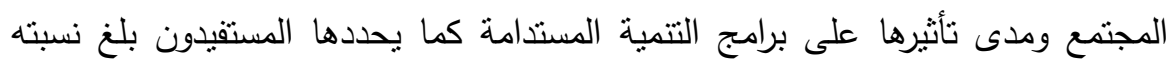

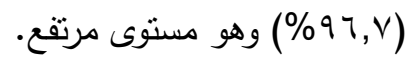

$$
\begin{aligned}
& \text { 0- القيم الجمالية: }
\end{aligned}
$$

جدول (ه 1): يوضح القيم الجمالية السائدة في المجتمع ومدى تأثبرها على برامج التنمية

\begin{tabular}{|c|c|c|c|c|c|c|c|c|c|c|}
\hline \multirow{3}{*}{ الترتيب } & \multirow{3}{*}{ الاتحراف } & \multirow{3}{*}{ الحسابي } & \multicolumn{6}{|c|}{ الاستجابات } & \multirow{3}{*}{ العبارات } & \multirow{3}{*}{ e } \\
\hline & & & \multicolumn{2}{|c|}{$\gamma$} & \multicolumn{2}{|c|}{ إلى حد ما } & \multicolumn{2}{|c|}{ نعم } & & \\
\hline & & & $\%$ & ك & $\%$ & ك & $\%$ & ك & & \\
\hline r & שT, & $r, 90$ & $r, V$ & $r$ & - & - & $q \vee, r$ & $1 . v$ & أحرص على النظافة & 1 \\
\hline$r$ & זT, & $r, 90$ & $r, V$ & $r$ & - & - & $q \vee, r$ & $1 . v$ & نظافة المنزل على & $r$ \\
\hline$\varepsilon$ & $\cdot, 0$ & r, VO & $r, v$ & $r$ & r. & r & $V V, r$ & 10 & ألثجع زراعة & $r$ \\
\hline 0 & $\cdot, \vee \wedge$ & $r, \cdot \varepsilon$ & $r \Lambda, r$ & r & $\varepsilon$. & $\varepsilon \varepsilon$ & r & ro & 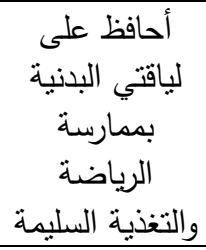 & $\varepsilon$ \\
\hline 1 & $\cdot, 9 Y$ & יז, & $T \Lambda, r$ & Vo & $1, \wedge$ & r & $r$. & r & القصائد الشعرية & 0 \\
\hline
\end{tabular}

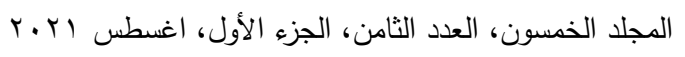

التزقيم الدولي 0826- ISSN 1110

التزقيم الدولي الموحد الإلكتروني 3178-2636 
مجلة العلوم البيئية

كلية الدراسات العليا والبحوث البيئية - جامعة عين شمس لهن

نجلاء حسن الخولي وآخرون

\begin{tabular}{|c|c|c|c|c|c|c|c|c|c|c|}
\hline \multirow{3}{*}{ الترتيب } & \multirow{3}{*}{ الانحراف المعياري } & \multirow{3}{*}{ المستوسطي } & \multicolumn{6}{|c|}{ الاستجابات } & \multirow{3}{*}{ العبارات } & \multirow{3}{*}{ p } \\
\hline & & & \multicolumn{2}{|c|}{$y$} & \multicolumn{2}{|c|}{ إلى حد ما } & \multicolumn{2}{|c|}{ نعم } & & \\
\hline & & & $\%$ & ك & $\%$ & 5 & $\%$ & ك & & \\
\hline 1 & $\cdot, Y O$ & $r, 90$ & $\cdot, 9$ & 1 & $r, V$ & $r$ & $97, \varepsilon$ & 1.7 & ألتفاؤل وبشاشَ على & 7 \\
\hline$r$ & • & $r, q 1$ & 1,1 & $r$ & 0,0 & 7 & $q Y, V$ & $1 \cdot r$ & الايجابية في المئى المواقف & V \\
\hline مستوى & $\cdot, r \wedge$ & $r, 0 q$ & & & & & ككل & & & \\
\hline
\end{tabular}

القيم الجمالية السائدة في المجتمع ومدى تأثيرها على برامج التتمية المستدامة كما يحددها المستقبدون، تمثلت فيما يلى :

• الترتيب الأول أحرص على التفاؤل وبشاشة الوجه وأحرص على النظافة الشخصية والمظهر اللائق، وأحرص على نظافة المنزل وترتيب أثاثه بنسبة (؟1\%,\%)، يليه الترتيب الثاني أحافظ على الايجابية في المواقف المختلفة بنسبة (و (\%))، وفي النهاية الترتيب الخامس أحافظ على لياقتي البدنية بممارسة الرياضة والتغذية السليمة بنسبة (1^\%)، وأخيراً التزتيب السادس استمع بقراءة القصائد الثعرية بنسبة (عه\%). • وبالنظر للجدول نجد أن نتائجه نشير إلي أن المتوسط العام للقيم الجمالية السائدة في المجتمع ومدى تأثثرها على برامج التتمية المستدامة كما بحددها المستفيدون بلغ نسبته (\%^7, و وهو مستوى مرتفع. • أنساق القيم السائدة في المجتمع ومدى تأثنرها على برامج التتمية المستدامة كما يحددها المستفيدون، تمثلت فيما يلي: 
وبالنظر للجدول نجد أن نتائجه نتير إلي أن المتوسط العام لأنساق القيم السائدة في

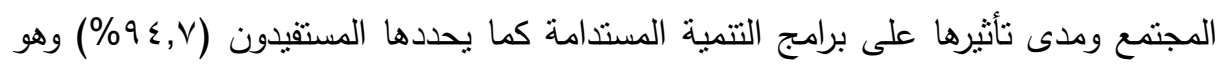
مسنوى مرتفع. • ومن خلا عرض نتائج الدراسة المتعلقة بمحور نسق القيم يحدد الباحثون أوجه الاتفاق والاختلاف والاستفادة للاراسات السابقه في محور نسق القيم كالآتى:

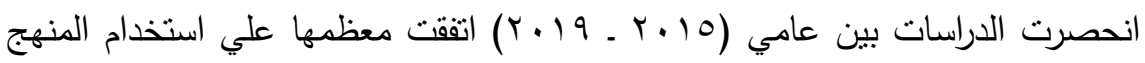
الوصفي التحليلي والمسح الاجتماعي والمنهج التاريخي ومنهج دراسة الحالة، واستخدمت بعض الدرسات أسلوب الملاحظه الموضوعية واستمارة جمع البيانات كما اتفقت معظم الدراسات في وسائل جمع البيانات وهي: (الملاحظة العلمية ـ استمارة تسجيل البيانات ـ استمارة استبيان ـ المقابلة الثخصية). ويلاحظ على الاراسات ما يالي: اــ ركزت الدراسات السابقة علي العوامل المؤثرة بشكل مبانشر وغير مباشر في تغيير نسق القيم זـ اغفلت الدراسات بعض العوامل المهمه المتعلقه بعملية تكوين القيم منل كيفية التربية والفئة

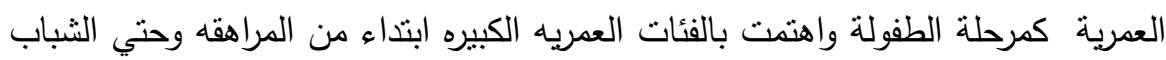
والعوامل التي تغير وتؤثر في تغيير نسق القير.

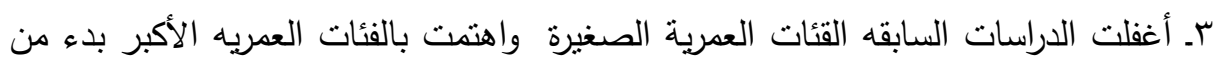
مرحلة المراهقه وحتي الثباب على اعتبار أنهم الفئة المؤثره في قيم المجتمع.

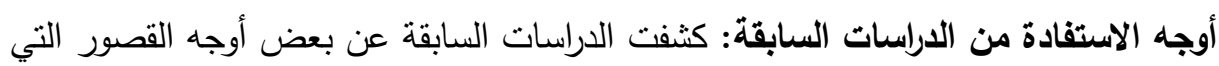

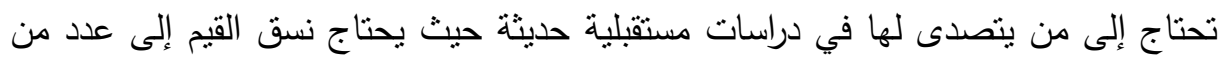
الدراسات والبحوث لسد بعض الجوانب التي لم يبحثها السابقون.

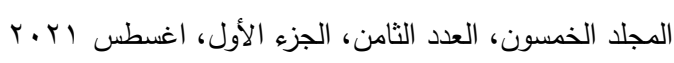

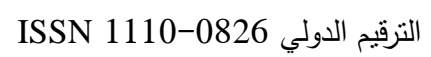

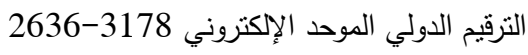


الموروثات الثعبية السائدة في المجتمع ومدى تأثيرها على برامج التنمية

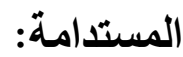

1-العادات والتقاليد: جدول (1 (1): يوضح العادات والتقاليد السائدة في المتمع ومدى تأثيرها على برامج التتمية المستدامة كما يحددها المستقيدون (ن=•• (1)

\begin{tabular}{|c|c|c|c|c|c|c|c|c|c|c|}
\hline \multirow{3}{*}{ 苫: } & \multirow{3}{*}{$\underline{\underline{E}}$} & \multirow{3}{*}{$\underline{E}$} & \multicolumn{6}{|c|}{ الاستجابات } & \multirow{3}{*}{ العبارات } & \multirow{3}{*}{ م م } \\
\hline & & & \multicolumn{2}{|c|}{$y$} & \multicolumn{2}{|c|}{ إلى حد ما } & \multicolumn{2}{|c|}{ نعم } & & \\
\hline & & & $\%$ & 5 & $\%$ & 5 & $\%$ & 5 & & \\
\hline IT & $\cdot, V \varepsilon$ & 1,04 & 71,1 & 71 & rT,T & Tד & $1 \leqslant, 0$ & 17 & معتبر ختان الإناث & 1 \\
\hline 11 & $\cdot,(1)$ & $1,0 \mathrm{~V}$ & 00,0 & 71 & $\Gamma_{1, \Lambda}$ & ro & $I T, V$ & $1 \varepsilon$ & $\begin{array}{c}\text { من عادات الأسرة الزواج المبكر } \\
\text { للإناث }\end{array}$ & $r$ \\
\hline $1 T$ & $\cdot, V_{1}$ & $1,1,0$ & $\vee \wedge, r$ & 17 & $\Lambda, r$ & 9 & $1 \Gamma, 7$ & 10 & 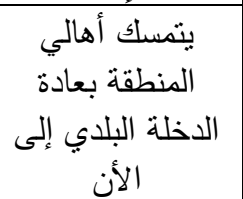 & $r$ \\
\hline 1. & $\cdot, 9$ & 1,99 & $\varepsilon \cdot, 9$ & $\leqslant 0$ & 19,1 & YI & $\varepsilon$. & $\varepsilon \varepsilon$ & 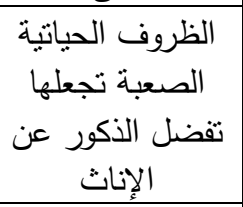 & $\varepsilon$ \\
\hline$\wedge$ & $\cdot, 79$ & r,To & 11,1 & $\pi$ & $\varepsilon,, q$ & $\leqslant 0$ & $\varepsilon V, r$ & or & نركت آثرات سيئا فيمية التفرقة بين التولد & 0 \\
\hline
\end{tabular}


مجلة العلوم البيئية

كلية الدراسات العليا والبحوث البيئية - جامعة عين شمس لئه

نجلاء حسن الخولي وآخرون

\begin{tabular}{|c|c|c|c|c|c|c|c|c|c|c|}
\hline \multirow{3}{*}{ E $_{E}$} & \multirow{3}{*}{ 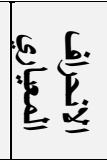 } & \multirow{3}{*}{$\underline{E}$} & \multicolumn{6}{|c|}{ الاستجابات } & \multirow{3}{*}{ العبارات } & \multirow{3}{*}{ م } \\
\hline & & & \multicolumn{2}{|c|}{$y$} & \multicolumn{2}{|c|}{ إلى حد ما } & \multicolumn{2}{|c|}{ نعم } & & \\
\hline & & & $\%$ & 5 & $\%$ & 5 & $\%$ & ك5 & & \\
\hline$\varepsilon$ & $\cdot, \sum \wedge$ & r,70 & - & - & $r \varepsilon, 0$ & Th & 70,0 & VY & التعليم أزال الكثير & 7 \\
\hline 7 & $\cdot, 00$ & $r, 0 \leqslant$ & $r, V$ & r = ( & $\varepsilon \cdot, q$ & $\leqslant 0$ & $07, \varepsilon$ & $T r$ & لأسرتها منل الولت نافعة & $V$ \\
\hline V & $\cdot, 00$ & סr, & $r, \tau$ & $\varepsilon$ & ov,r & זד & $r q, 1$ & $\varepsilon r$ & تلقى البنات نفس الذكور & $\wedge$ \\
\hline 0 & $\cdot, 7$ & $r, T \leq$ & $7, \varepsilon$ & V & rr, & rt & V. & $V V$ & المقابر في العادات زيارة & 9 \\
\hline 9 & $\cdot, \vee \wedge$ & r,Tr & 19,1 & YI & r. & سז & $0 \cdot, 9$ & 07 & للفض المنازعات عرب للجهات اللجوء & 1. \\
\hline r & $\cdot, \varepsilon)$ & $r, \wedge q$ & $r, \tau$ & $\varepsilon$ & $r, 7$ & $\varepsilon$ & $q r, v$ & $1 \cdot r$ & 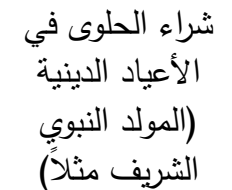 & 11 \\
\hline 1 & & $r, q r$ & $1, \wedge$ & r & $r, 7$ & $\varepsilon$ & $9 \varepsilon, 0$ & $1 \cdot \varepsilon$ & توزيع العيدية على الأطفال في العيد & IT \\
\hline r & דr, • & $r, q$ & $1, \wedge$ & r & \rceil, $乏$ & V & 91,1 & 1.1 & 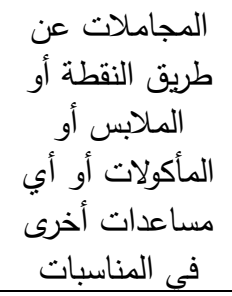 & r \\
\hline متوسط مستو & $\cdot, Y V$ & r, & & & & & د ككل & & & \\
\hline & & & طس & SN & |جزي ا & ل & خرن، العدد & 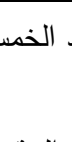 & & 115 \\
\hline
\end{tabular}


العادات والتقاليد السائدة في المجتمع ومدى تأثيرها على برامج التتمية المستدامة كما يحددها المستقيدون، تمثلت فيما يلى:

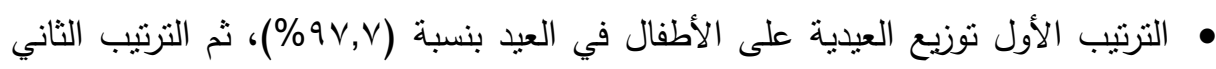

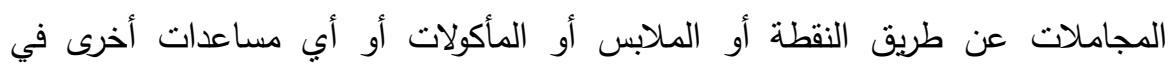

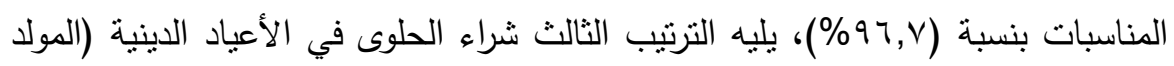

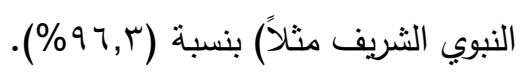

• وفي النهاية الترتيب الثاني عشر يعتبر ختان الإناث من العادات القديمة التي يتم ممارستها حتى الآن بنسبة (1\%)، وأخيراً الترتيب الثالث عشر بتمسك أهالي المنطقة

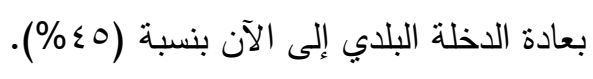

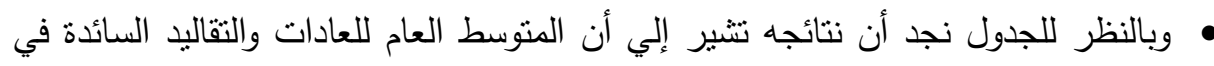

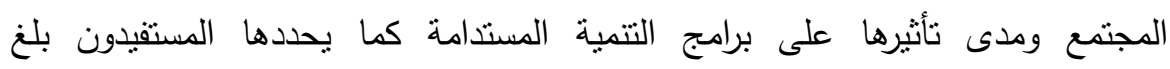

$$
\text { نسبته (\%VV) وهو مستوى متوسط. }
$$

r- r r المعتقدات الشعبية:

\begin{tabular}{|c|c|c|c|c|c|c|c|c|c|c|}
\hline \multirow{3}{*}{ 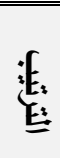 } & \multirow{3}{*}{$\underline{E}$} & \multirow{3}{*}{$\underline{E}$} & \multicolumn{6}{|c|}{ الاستجابات } & \multirow{3}{*}{ العبارات } & \multirow{3}{*}{ r } \\
\hline & & & \multicolumn{2}{|c|}{$y$} & \multicolumn{2}{|c|}{ إلى حـ ما } & \multicolumn{2}{|c|}{ نعم } & & \\
\hline & & & $\%$ & ك & $\%$ & ك & $\%$ & ك & & \\
\hline 1 & $\cdot, 01$ & $r, 70$ & 0,0 & 7 & $r \leqslant, 0$ & TV & v. & VV & ولأِّارة أضرحة للتبرك & 1 \\
\hline$r$ & •, 70 & $r, 01$ & $\Lambda, r$ & 9 & $r, V$ & ry & 09,1 & 70 & الاعتقاد في السحر & r \\
\hline
\end{tabular}

جدول (IV): يوضح المعتقدات الثعبية السائدة في المجتمع ومدى ثأثيرها على برامج التتمية المستدامة كما يحددها المستفيدون (ن= • (1)

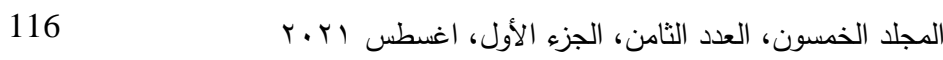
التزقيم الدولي 0826- ISSN 1110 الترقيم الدولي الموحد الإلكتروني 3178-2636 لإلي 
مجلة العلوم البيئية

كلية الدراسات العليا والبحوث البيئية - جامعة عين شمس لبيه

نجلاء حسن الخولي وآخرون

\begin{tabular}{|c|c|c|c|c|c|c|c|c|c|c|}
\hline \multirow{3}{*}{ E: } & \multirow{3}{*}{ 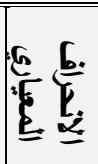 } & \multirow{3}{*}{$\underline{E}$} & \multicolumn{6}{|c|}{ الاستجابات } & \multirow{3}{*}{ العبارات } & \multirow{3}{*}{ م } \\
\hline & & & \multicolumn{2}{|c|}{$y$} & \multicolumn{2}{|c|}{ إلى حد ما } & \multicolumn{2}{|c|}{ نعم } & & \\
\hline & & & $\%$ & ك & $\%$ & ك & $\%$ & ك & & \\
\hline r & $\cdot, 7 \leq$ & Y,OV & $\wedge, r$ & 9 & $r\rceil, \varepsilon$ & $r q$ & 70,0 & VY & الاعتقاد في الأحلام & r \\
\hline 0 & $\cdot, V T$ & $Y, Y \wedge$ & $17, \varepsilon$ & 11 & $r q, 1$ & $\varepsilon r$ & $\varepsilon \varepsilon, 0$ & $\leqslant 9$ & 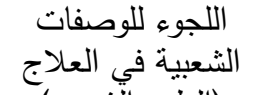 & $\varepsilon$ \\
\hline V & $\cdot, \wedge r$ & 1,97 & $r_{0,0}$ & rq & Tr,V & Tr & M , ו & ro & في الأسبِل يوع والتفائل & 0 \\
\hline 9 & $\cdot, \wedge)$ & $1, \wedge$ & $\varepsilon \varepsilon, 0$ & $\varepsilon 9$ & $r \cdot, q$ & T纟 & $r \varepsilon, 0$ & rV & 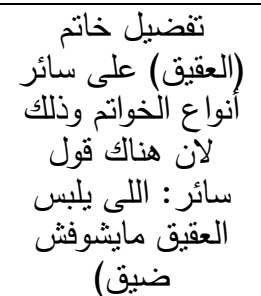 & 7 \\
\hline r & $\cdot, \vee q$ & $1, \varepsilon V$ & $V \cdot, q$ & Vᄉ & $1 \cdot, 9$ & 14 & $1 \wedge, r$ & $r$. & 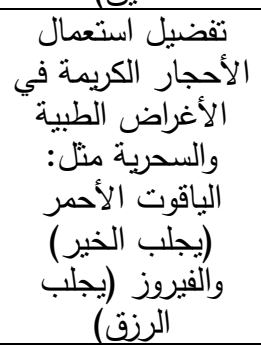 & V \\
\hline $1 \varepsilon$ & $\cdot, \vee 7$ & $1, \varepsilon \leqslant$ & $V Y, V$ & $\Lambda$. & $1 \cdot, 9$ & Ir & $17, \varepsilon$ & 11 & 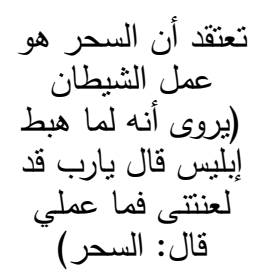 & $\Lambda$ \\
\hline 1. & $\cdot, \vee q$ & $1, V r$ & $\varepsilon \Lambda, r$ & or & $r \cdot, q$ & T纟 & $r \cdot, q$ & Tr & تثفاعل أماكن معينة تنتاءم & 9 \\
\hline
\end{tabular}

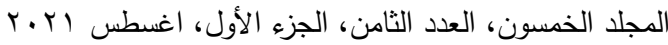

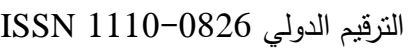

الترقيم الدولي الموحد الإكتروني 3178-2636 
مجلة العلوم البيئية

كلية الدراسات العليا والبحوث البيئية - جامعة عين شمس لبه

نجلاء حسن الخولي وآخرون

\begin{tabular}{|c|c|c|c|c|c|c|c|c|c|c|}
\hline \multirow{3}{*}{$\begin{array}{l}E_{i} \\
E:\end{array}$} & \multirow{3}{*}{$\underline{\underline{E}}$} & \multirow{3}{*}{$\underline{E}$} & \multicolumn{6}{|c|}{ الاستجابات } & \multirow{3}{*}{ العبارات } & \multirow{3}{*}{ م } \\
\hline & & & \multicolumn{2}{|c|}{$\gamma$} & \multicolumn{2}{|c|}{ إلى حد ما } & \multicolumn{2}{|c|}{ نعم } & & \\
\hline & & & $\%$ & ك & $\%$ & ك5 & $\%$ & ك & & \\
\hline$\varepsilon$ & $\cdot, \lambda)$ & $r, Y q$ & $r), \Lambda$ & $r \varepsilon$ & $r V, r$ & r. & $0 ., 9$ & 07 & 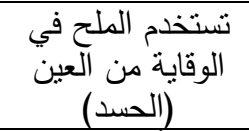 & 1. \\
\hline 10 & $\cdot, V \vee$ & $1, \pi \wedge$ & $\vee q, 1$ & $\Lambda V$ & $r, \tau$ & $\varepsilon$ & IV,r & 19 & تعتقد أن الشخص (المريض & 11 \\
\hline$\wedge$ & $\cdot, 9$ & س ו, 1, & 0 . & 00 & IV,r & 19 & $r$ r,V & ד r & النبوي بقام احتفال المولد & ir \\
\hline 11 & $\cdot, \wedge$ & 1,7 & 7. & 77 & $r$. & r & $r$. & Yr & القادم من اليمين & r \\
\hline Ir & $\cdot, \wedge$ & 1,0 & 79,1 & VT & 11,1 & r & 19,1 & YI & تجتقد بأن الأرواح في مكان & $1 \varepsilon$ \\
\hline 7 & $\cdot, V_{1}$ & $r, I T$ & $r$. & rY & $\varepsilon \wedge, r$ & or & N ו, & o & تعنتق بأن أرواحا & 10 \\
\hline منتوسط & $1, \leqslant 0$ & $1,9 \leq$ & & & & & كل & & & \\
\hline
\end{tabular}

المعتقات الثعبية السائدة في المجتمع ومدى تأثثرها على برامج التتمية المستدامة كما يحددها المستقيدون، تمثلت فيما يلى:

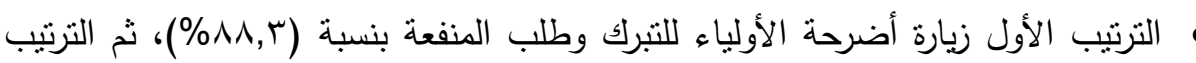

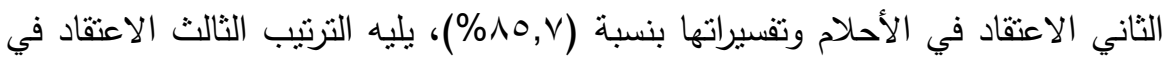

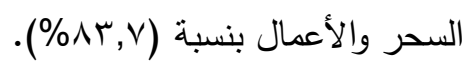

118 المجلد الخمسون، العدد الثامن، الجزء الأول، اغسطس آY.r. التزقيم الدولي 0826-1110 تصني الترقيم الدولي الموحد الإكتروني 3178-2636 
• وفي النهاية التزتيب الرابع عشر تعتقد أن السحر هو عمل الثنيطان (بروى أنه لما هبط

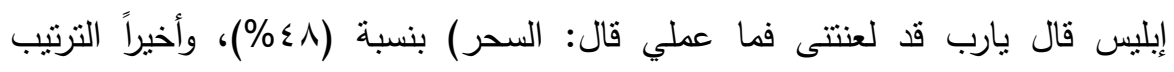
الخامس عشر تعتقد أن الثخص المجذوب (المريض عقليا) له قدرات روحية مثنا:

$$
\text { (مكثوف عنه الحجاب) بنسبة (7 § \%). }
$$

• وبالنظر للجدول نجد أن نتائجه تشير إلي أن المتوسط العام للمعتقدات الثُبية السائدة في المجتمع ومدى تأثيرها على برامج التتمية المستدامة كما يحددها المستقيدون بلغ نسبيته

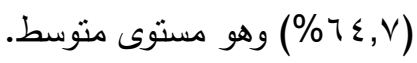

$$
\begin{aligned}
& \text { r-الأدب الثعبي: }
\end{aligned}
$$

جدول (1) (1): يوضح الأدب الثعبي السائد في المجتمع ومدى تأثيره على برامج التنمية

\begin{tabular}{|c|c|c|c|c|c|c|c|c|c|c|}
\hline \multirow{3}{*}{ 苂: } & \multirow{3}{*}{ 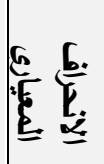 } & \multirow{3}{*}{$\underline{E}$} & \multicolumn{6}{|c|}{ الاستجابات } & \multirow{3}{*}{ العبارات } & \multirow{3}{*}{ r } \\
\hline & & & \multicolumn{2}{|c|}{ ע } & \multicolumn{2}{|c|}{ إلى حد ما } & \multicolumn{2}{|c|}{ نعم } & & \\
\hline & & & $\%$ & ك & $\%$ & 5 & $\%$ & ك & & \\
\hline 1 & $\cdot, \Sigma V$ & $r, \wedge \vee$ & 0,0 & 7 & $1, \wedge$ & r & $q r, V$ & $1 \cdot r$ & تشتخدية التشبة لتوصنيل & 1 \\
\hline 0 & $\cdot, 7 V$ & $r, T \leqslant$ & $1 \cdot, 9$ & IT & $1 \leqslant, 0$ & 17 & $V \varepsilon, 0$ & Ar & 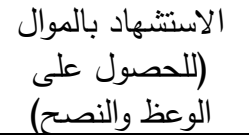 & $r$ \\
\hline r & $\cdot, \leqslant 9$ & $r, 10$ & 0,0 & 7 & $\varepsilon, 0$ & 0 & 9 . & 99 & 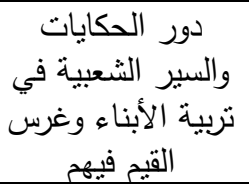 & $r$ \\
\hline r & $\cdot, \sum \wedge$ & $r, \wedge$ & $r, \tau$ & $\varepsilon$ & $I Y, V$ & $1 \varepsilon$ & $\Delta r, \tau$ & 94 & الأغنية الشعبية بيتم & $\varepsilon$ \\
\hline
\end{tabular}

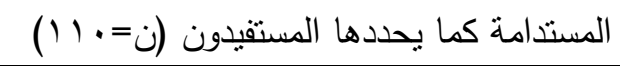

$$
\text { المجلد الخمسون، العدد الثامن، الجزء الأول، اغسطس اY ب. }
$$

التزقيم الدولي 0826-0 العدون

الترقيم الدولي الموحد الإكتروني 3178-2636 
مجلة العلوم البيئية

كلية الدراسات العليا والبحوث البيئية - جامعة عين شمس لهـ

نجلاء حسن الخولي وآخرون

\begin{tabular}{|c|c|c|c|c|c|c|c|c|c|c|}
\hline \multirow{3}{*}{ E: } & \multirow{3}{*}{ 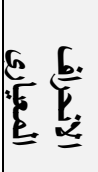 } & \multirow{3}{*}{$\underline{E}$} & \multicolumn{6}{|c|}{ الاستجابات } & \multirow{3}{*}{ العبارات } & \multirow{3}{*}{ p } \\
\hline & & & \multicolumn{2}{|c|}{$y$} & \multicolumn{2}{|c|}{ إلى حد ما } & \multicolumn{2}{|c|}{ نعم } & & \\
\hline & & & $\%$ & ك5 & $\%$ & ك5 & $\%$ & ك5 & & \\
\hline 7 & $\cdot, \wedge 7$ & 1,09 & 70,0 & $V Y$ & 1 . & 11 & $r \leqslant, 0$ & $r v$ & نشتهرد أطعمه معينة & 0 \\
\hline$\varepsilon$ & $\cdot, 7$ & $r, Y \wedge$ & 9,1 & 1. & $r, \tau$ & $\varepsilon$ & $\Lambda V, r$ & 97 & وجأعياد أطعمة مرنبطة & 7 \\
\hline مستوى & $\cdot, r \wedge$ & $r, 09$ & \multicolumn{8}{|c|}{ البعد ككل } \\
\hline
\end{tabular}

الأدب الثعبي السائد في المجتمع ومدى تأثثره على برامج التتمية المستدامة كما يحددها المستقفيدون، تمنلت فيما يلى:

- - الترتيب الأول تستخدم الأمثال الثعبية لتوصيل فكرة معينة بنسبة (90,v\%)، ثم الترتيب

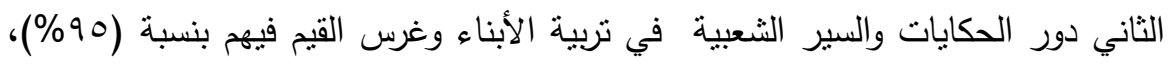

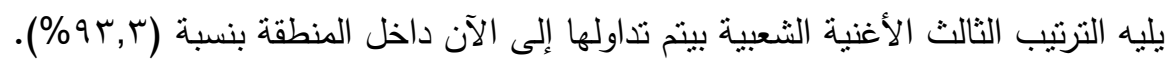

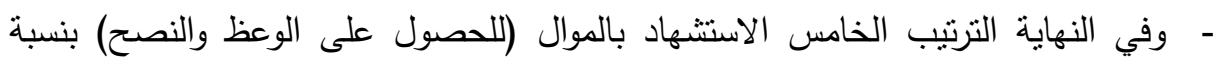

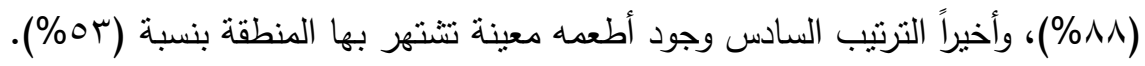
- - وبالنظر للجدول نجد أن نتائجه نتشير إلي أن المتوسط العام للأدب الثعبي السائد في المجتمع ومدى تأثيره على برامج التتمية المستدامة كما يحددها المستقبدون بلغنسبته إنهات

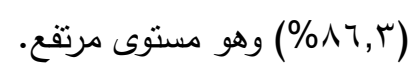

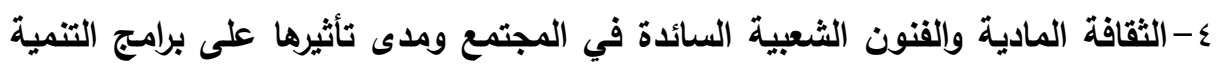
المستدامة كما يحددها المستفيدون، تمثلت فيما يلي: 
مجلة العلوم البيئية - مالية

كلية الدراسات العليا والبحوث البيئية - جامعة عين شس البئ

نجلاء حسن الخولي وآخرون

جدول (9 (1): يوضح الثقافة المادية والفنون الثعبية السائدة في المجتمع ومدى تأثيرها على

\begin{tabular}{|c|c|c|c|c|c|c|c|c|c|c|}
\hline \multirow{3}{*}{ الترتيب } & \multirow{3}{*}{ الانعراف } & \multirow{3}{*}{ الحستوسط } & \multicolumn{6}{|c|}{ الاستجابات } & \multirow{3}{*}{ العبارات } & \multirow{3}{*}{ p } \\
\hline & & & \multicolumn{2}{|c|}{$y$} & \multicolumn{2}{|c|}{ إلى حد ما } & \multicolumn{2}{|c|}{ نعم } & & \\
\hline & & & $\%$ & ك & $\%$ & 5 & $\%$ & ك & & \\
\hline$\wedge$ & $\cdot, 0 \mathrm{~V}$ & $r, 17$ & 9,1 & 1. & 70,0 & $V Y$ & $r_{0,0}$ & rA & معين للمسكن شيكل & 1 \\
\hline r & ד & $r, 9 r$ & $r, V$ & $r$ & $r, V$ & $r$ & $9 \leqslant, 0$ & $1 \cdot \varepsilon$ & بوجد مرافق & $r$ \\
\hline 9 & $\cdot, 9 \leq$ & 1,70 & $T V, r$ & $V \varepsilon$ & - & - & $r$ r,V & ru & تتميز المنطقة & $r$ \\
\hline 1 & • & r, Yo & $1 \cdot, 9$ & ir & $r, r$ & $r$ & $\wedge \uparrow, \varepsilon$ & 90 & طوأث تغيرات العثى خلالى & $\varepsilon$ \\
\hline 1 & שT, & $r, 90$ & $r, V$ & $r$ & - & - & $9 \vee, r$ & $1 . V$ & تبوجد خدمات بالمنطية & 0 \\
\hline$r$ & $\cdot, r q$ & $r, \wedge q$ & $r, V$ & $r$ & 0,0 & 7 & $91, \wedge$ & 1.1 & بوجد خدماتة & 7 \\
\hline 0 & $\cdot, \leq 7$ & $r, \wedge T$ & $\varepsilon, 0$ & 0 & $\varepsilon, 0$ & 0 & $9 \cdot, 9$ & $1 \ldots$ & بوجد خدمات & V \\
\hline V & •, or & $Y, \varepsilon Y$ & 1,1 & r & $0 \leqslant, 0$ & 7. & $\varepsilon r, \tau$ & $\varepsilon \wedge$ & بوجد خدافية وريات & $\wedge$ \\
\hline
\end{tabular}

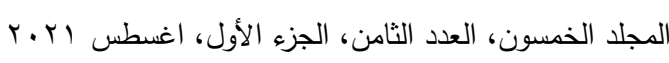

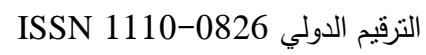

الترقيم الدولي الموحد الإلكتروني 3178-2636 
مجلة العلوم البيئية

كلية الدراسات العليا والبحوث البيئية - جامعة عين شمس لفئة

نجلاء حسن الخولي وآخرون

\begin{tabular}{|c|c|c|c|c|c|c|c|c|c|c|}
\hline \multirow{3}{*}{ الترتيب } & \multirow{3}{*}{ المعياري } & \multirow{3}{*}{ الحسابي } & \multicolumn{6}{|c|}{ الاستجابات } & \multirow{3}{*}{ العبارات } & \multirow{3}{*}{ p } \\
\hline & & & \multicolumn{2}{|c|}{$y$} & \multicolumn{2}{|c|}{ إلى حـ ما } & \multicolumn{2}{|c|}{ نعم } & & \\
\hline & & & $\%$ & 5 & $\%$ & s & $\%$ & ك5 & & \\
\hline$\varepsilon$ & -,$\varepsilon r$ & $\uparrow, \wedge \wedge$ & $r, \tau$ & $\varepsilon$ & $\varepsilon, 0$ & 0 & 91,1 & 1.1 & بأشغال بيدوية & 9 \\
\hline مستنوى مرتفع & $\cdot, Y_{I}$ & $r, T)$ & \multicolumn{8}{|c|}{ البعد ككل } \\
\hline
\end{tabular}

الثقافة المادية والفنون الثعبية السائدة في المجتمع ومدى تأثنرها على برامج التتمية المستدامة كما يحددها المستقيدون، تمثلت فيما يلى:

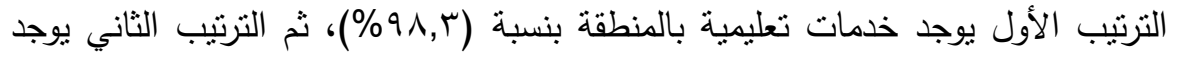

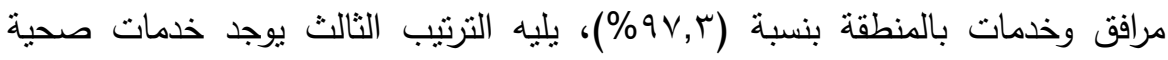
بالمنطقة بنسبة (r, 97\%).

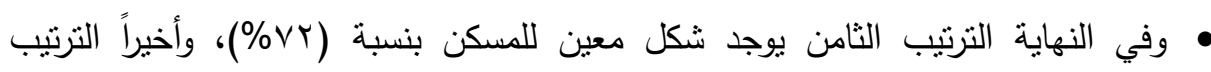
التاسع تتميز المنطقة بزى معين بنسبة (00\%). • وبالنظر للجدول نجد أن نتائجه نتشير إلي أن المتوسط العام للتقافة المادية والفنون الثعبية

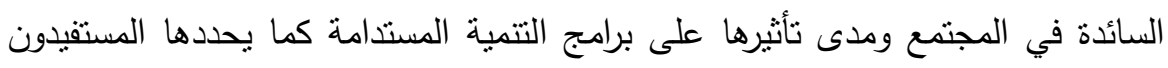
بلغ نسبته (\%^V) وهو مستوى مرتفع. • ومن خلال عرض نتائج الدراسة المتعلقة بمحور الموروثات الثعبية يحدد الباحثون أوجه الأتفاق والأختلاف من الدراسات السابقه في محور الموروثات الثعبية كالآتى:

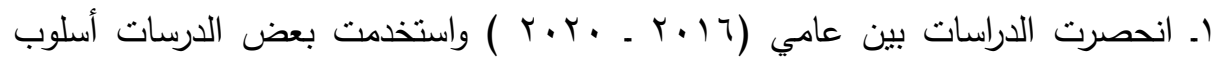
الملاحظى الموضوعية واستمارة جمع البيانات r. اعتمدت معظم الدراسات في وسائل جمع البيانات على (الملاحظة العلمية ـ استمارة تسجيل البيانات ـ استمارة استنيان ـ الدقابلة الثخصية)

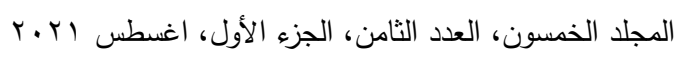

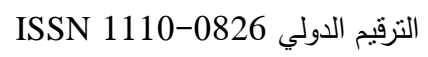

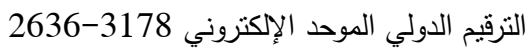


rـ ركزت الدراسات السابقة على الموروثات الثعبيةومدى تأثيرها على الحياة المجتمعية

وخصوصا في المجتمعات الريفية لأنها الأكثر تمسكا بالموروثات الثعبية.

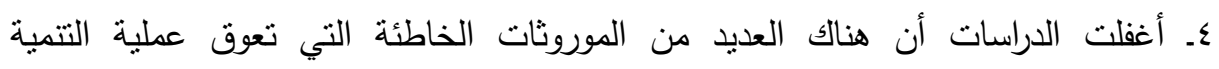

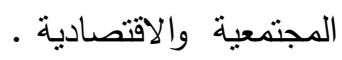

هـ تتاولت الدراسات السابقة الموروثات الثعبية لمناطق معينة وتجاهلت الموروثات الثعبيه للمدن وهذا مما يؤخذ عليها فلكل مكان موروثاته الثعبية الخاصة به.

الآثار الناتجة عن المعوقات الثقافية والاجتماعية لبرامج التنمية المستدامة: جدول (·r): يوضح الآثار الناتجة عن المعوقات الثقافية والاجتماعية لبرامج التتمية

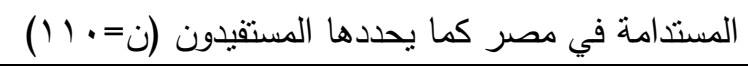

\begin{tabular}{|c|c|c|c|c|c|c|c|c|c|c|}
\hline \multirow{3}{*}{ الترتيب } & \multirow{3}{*}{ الانحراف } & \multirow{3}{*}{ المستوسط المسي } & \multicolumn{6}{|c|}{ الاستجابات } & \multirow{3}{*}{ العبارات } & \multirow{3}{*}{ r } \\
\hline & & & \multicolumn{2}{|c|}{ 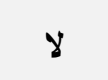 } & \multicolumn{2}{|c|}{ إلى حا } & \multicolumn{2}{|c|}{ نعم } & & \\
\hline & & & $\%$ & ك5 & $\%$ & ك5 & $\%$ & ك5 & & \\
\hline 1 & $\cdot, Y_{1}$ & $r, 90$ & - & - & $\varepsilon, 0$ & 0 & 90,0 & 1.0 & الفقر & 1 \\
\hline$r$ & $\cdot, Y_{O}$ & $r, q \leq$ & - & - & $7, \varepsilon$ & $V$ & 94,7 & $1 . r$ & البطالة & $r$ \\
\hline$r$ & $\cdot, Y_{O}$ & $r, q \leq$ & - & - & $7, \Sigma$ & $V$ & 94,7 & $1 \cdot r$ & الأمية & $r$ \\
\hline$r$ & $\cdot, Y_{0}$ & $r, q \leq$ & - & - & $7, \varepsilon$ & $\mathrm{V}$ & $9 r, 7$ & $1 . r$ & انتشار العشوائيات & $\varepsilon$ \\
\hline r & $\cdot, r_{0}$ & $r, q \leq$ & - & - & $7, \varepsilon$ & V & 94,7 & 1. & تدنى ثقافة وقيم & 0 \\
\hline$r$ & $\cdot, Y T$ & $r, 90$ & - & - & 0,0 & 7 & $9 \leqslant, 0$ & $1 \cdot \varepsilon$ & غياب الوعى الثقافى & 7 \\
\hline 1 & $\cdot, Y_{1}$ & $r, 90$ & - & - & $\varepsilon, 0$ & 0 & 90,0 & 1.0 & تدنى المستوى & $V$ \\
\hline مرتفوى & $\cdot, Y Y$ & $r, q \leq$ & & & & & & S & & \\
\hline
\end{tabular}

الآثار الناتجة عن المعوقات الثقافية والاجتماعية لبرامج التتمية المستدامة في مصر كما يحددها المستقيدون، تمثلت فيما يلى:

الترقيم الدولي 0826-0 العند الترقيم الدولي الموحد الإلكتروني 3178-2636 


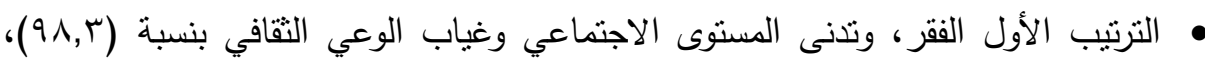

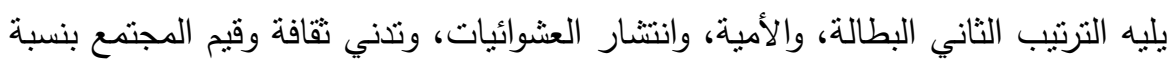

• وبالنظر للجدول نجد أن نتائجه نتير إلي أن المتوسط العام للآثار الناتجة عن المعوقات

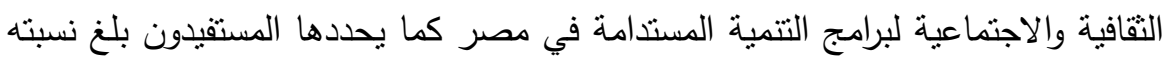

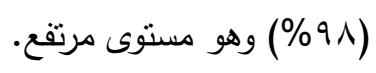

\section{مقترحات لمواجهة المعوقات الثقافية والاجتماعية لبرامج التنمية المستدامة في}

$$
\text { مصر كما يحددها المستفيدون، تمنلت فيما يلي: }
$$

جدول (r)): يوضح مقترحات لمواجهة المعوقات الثقافية والاجتماعية لبرامج التتمية

\begin{tabular}{|c|c|c|c|c|}
\hline الترتيب & $\%$ & ك5 & العبارات & 5 \\
\hline 1 & $V T, T$ & 1) & إقامة مشروعات صغيرة للشباب للقضاء على مشكلة البطالة & 1 \\
\hline $\mathrm{V}$ & $r \cdot, q$ & rr & تتمية الوعى الثقافي والبيئي للحفاظ على الآثار بالمنطقة & r \\
\hline$r$ & $7 \cdot, 9$ & TV & عمل مشروعات تتموية للأسر الفقيرة & $r$ \\
\hline 1. & $1 \pi, 7$ & 10 & التوعية بأهمية المشاركة المجتمعية والسياسية & $\varepsilon$ \\
\hline 9 & $17, \varepsilon$ & 11 & إقامة ندوات للتوعية الصحية & 0 \\
\hline 0 & $r, \wedge$ & ro & القضاء على العشوائيات والفقر والبطالة & 7 \\
\hline 7 & $r \leqslant, 0$ & rV & تتفيذ برامح لمحو الأمية وتعليم الكبار & $\mathrm{V}$ \\
\hline$\Lambda$ & 19,1 & Y) & عمل برامج للتوعية والنتقيف الصحي & $\Lambda$ \\
\hline$r$ & $T V, r$ & $V \leqslant$ & إقامة برامج تدريبية علي الحرف التزاثية للحفاظ عليها & 9 \\
\hline$\varepsilon$ & $r r, V$ & r & تقديم قروض لتنفيذ مشروعات صغيرة للشباب & 1. \\
\hline
\end{tabular}

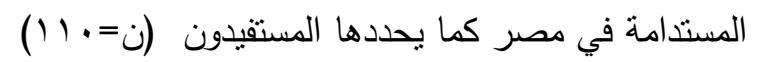

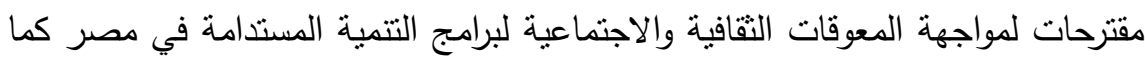
يحددها المستقيدون، تمثلت فيما يلى : 


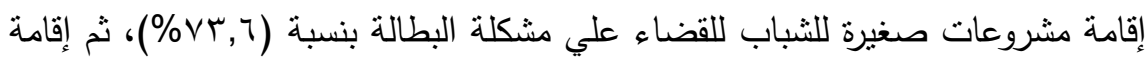

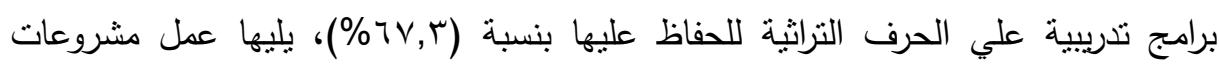
تتموية للأسر الفقيرة بنسبة (9, • ؟\%)، وأخيراً التوعية بأهمية المشاركة المجتمعية والسياسية

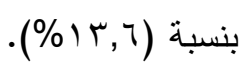

الروية المستقبلية المقترحة لمواجهة المعوقات الثقافية والاجتماعية لبرامج التنمية المستدامة في مصر:

ضرورة تكاتف جهود المؤسسات صاحبة القرار (البلدية، المحافظة، المؤسسات الحكومية،

$$
\text { مؤسسات المجتمع المدنى) فى تطوير حى الدرب الاحمر . }
$$

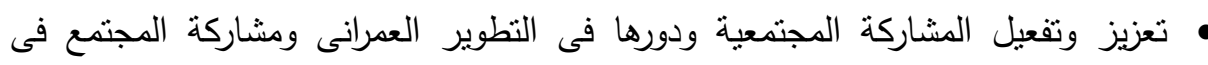

$$
\text { وضع الاحتياجات اللززمة. }
$$

• نطوير الأسواق الشعبية والتراثية بطريقة جذابة وجميلة تتاسب المكان جمالياً ووظيفياً

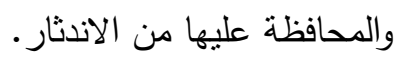

• توفير التمويل الكافى واللازم للحفاظ على الأبنية التراثية وترميمها وإعادة تأهيلها

واستخدامها.

• وضع قوانين وأنظمة تختص بحماية المناطق التاريخية والآثرية بشكل عام.

• أحياء الحرف النقليدية وتأهيل الكوادر المتخصصة.

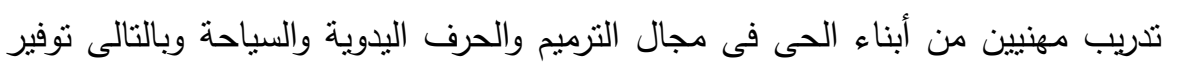

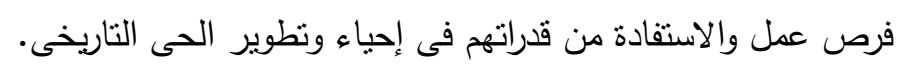

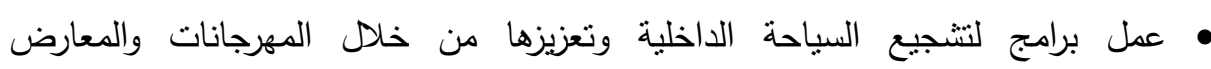

والأنشطة.

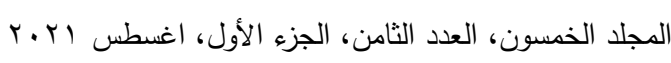

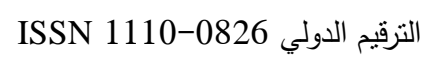

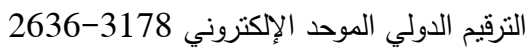


• مشاركة السكان فى إصلاح البيوت سواء تللك التى تضررت، أو القيام بعمل صيانة دورية

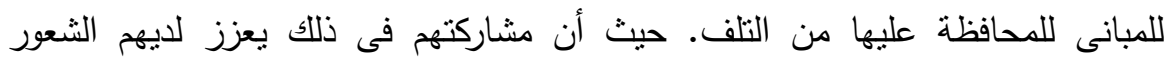
بالانتماء للبيوت والحى بشكل عام ويدفعهم للحفاظ عليه.

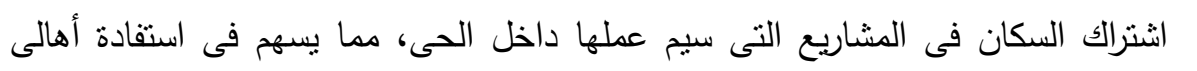

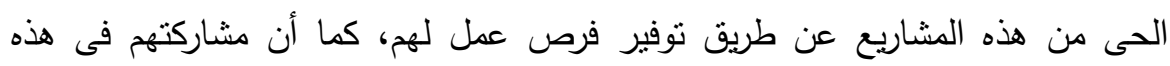
المشاريع يشعرهم بالإنتماء إليها. محافظة أهالى الحى على نظافتة، حيث أنه إضافة لمحافظتهم على نظافة بيوتهم لابد لهم إلى لطاء من الحفاظ على نظافة ممراته، أحواثشه، وساحته بحيث تثقى دائماً نظيفة. إنشاء شركة مساهمة عامة لنطوير حى الدرب الأحمر وتتولى عملية إنشاء مرافق سياحية إنهاء (فنادق - مطاعم وغيرها...) ضمن النسيج العمرانى للحى التاريخى.

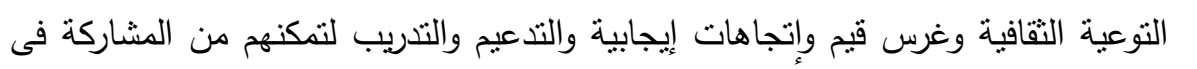
عملية التتمية. هالآخذ برأى المواطن العادى ومعرفة احتياجاتة الملحة والمشكلات التنتواجهة والتنخل العلمالموضوعى المخطط وإضافة مايمكن من أجل الارتقاء بالمواطن البسيط وتحسين مستوى المعيشة. تشجيع المشروعات التتموية المرتبطة بمحو الأمية والتدريب التقنبوالأهنمام بزيادة عملية التدريب للمواطن على حرفة وإيجاد فرص عمل له.

\section{تموسياهت المهيد}

• تشجيع التكامل الاجتماعي لتعزيز جميع حقوق الإنسان وحمايتها.

• حماية أفكار المواطنين من خطورة إتباع المشعوذين والسحرة. • العمل على كثافة المؤتمرات والندوات التى تهدف إلى رفع مستوى الوعى الدينى القيمى.

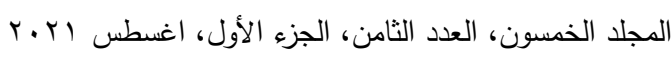

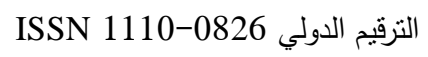

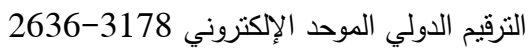


• العمل على رفع مستوى الوعى البيئى للأفراد بصفة عامة وسكان المناطق النائية خاصة.

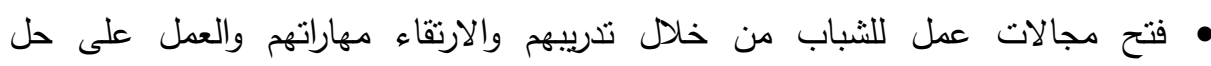
مشكلاتهم. • متابعة الهيئات الحكومية والأهلية للتأكد من تطبيقها البرامج المنوط بها من جانب الوزارات المختلفة.

• الإسراع بخطى التنمية بالمناطق العشوائية لمواجهة الفقر . • المساواة في الحصول على التعليم والرعاية الصحية الأولية. • • استثمار الموارد والإمكانبات المادية والبشرية والتكنولوجية المناحة. • تحسين الظروف المعيشية والصحية خاصة في المناطق العشوائية. • تقديم الدعم والتمويل اللازم للمشروعات والصناعات الصغيرة والمتتاهية الصغر .

\section{المرالئar}

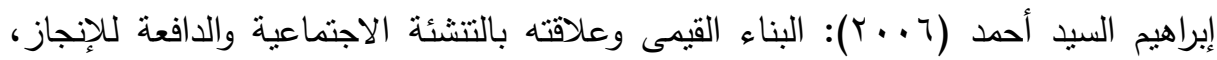

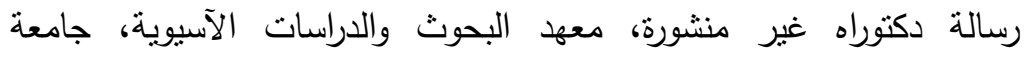
الزقازيق، ص صكراه

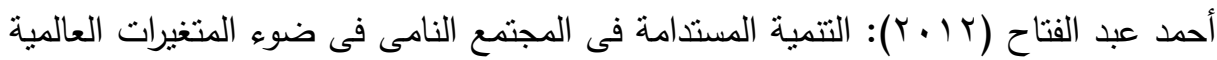

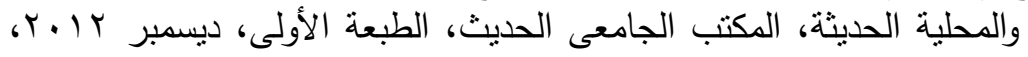
صه.

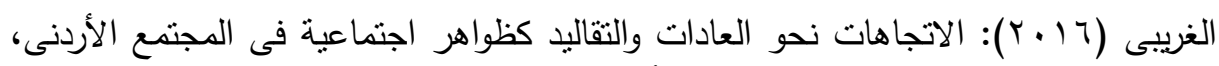

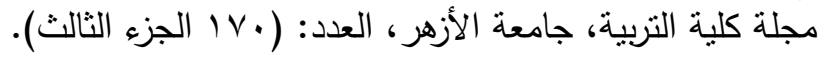

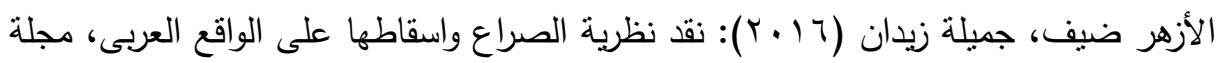

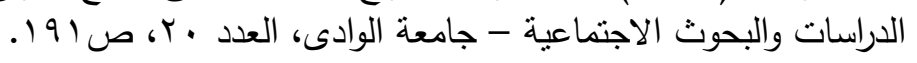

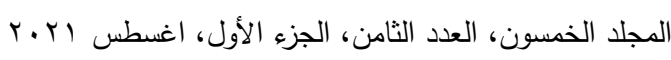

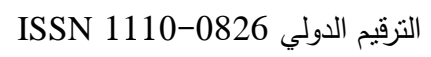

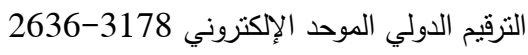




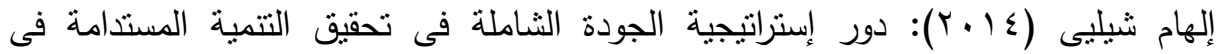

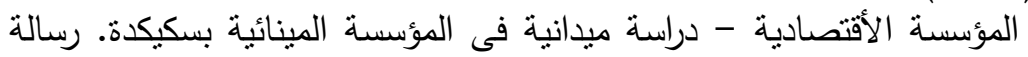

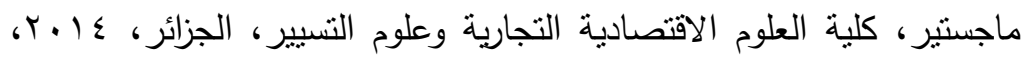

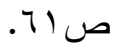

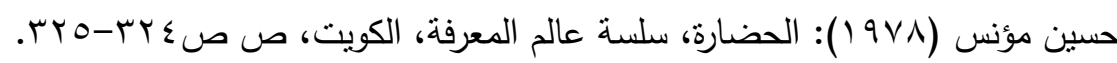

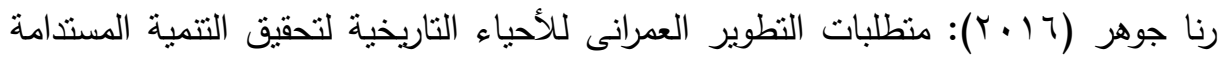

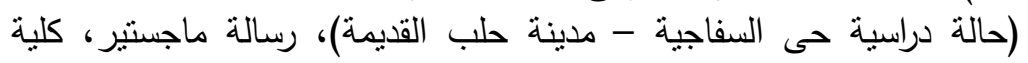

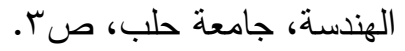

ريهان عبد اللطيف (9 . . ץ): المعوقات النفسية والاجتماعية وانعكاساتها على مشاركة المرأة

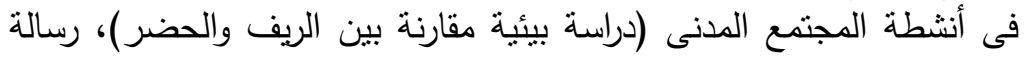

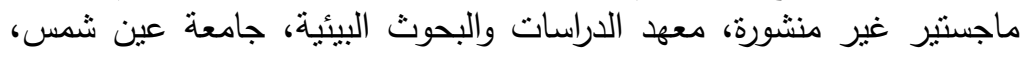

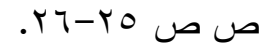

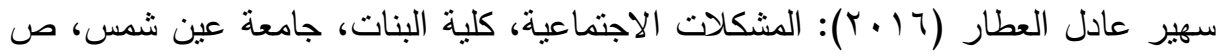

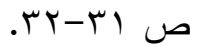

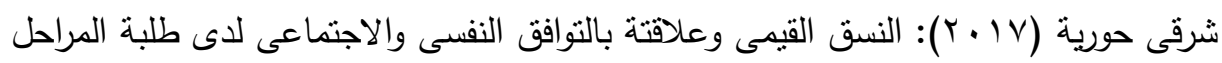

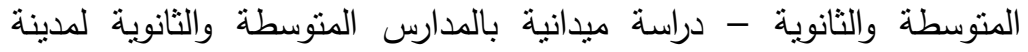
مستغانعم، كلية العلوم الاجتماعية، جامعة وهران.

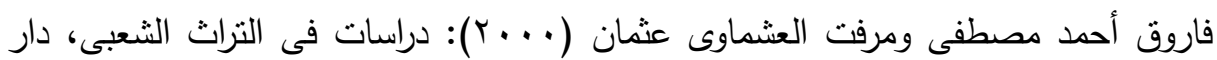

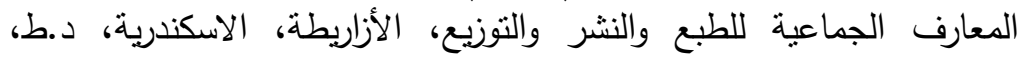

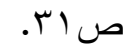

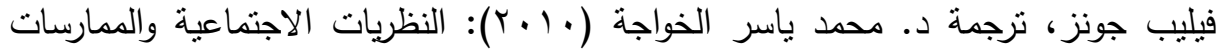
البحثية، مصر العربية للنشر والتوزيع، ص داهي 10.

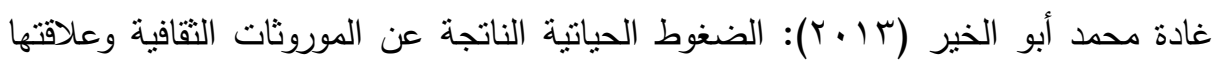

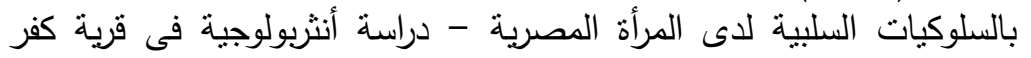
طهرمس بالجيزة. رسالة ماجستير غير منشورة، معهد الدراسات والبحوث البيئية، جامعة عين شمس، صعالـ ماجئر

128

$$
\begin{aligned}
& \text { المجلد الخمسون، العدد الثامن، الجزء الأول، اغسطس Y.r.T } \\
& \text { التزقيم الدولي 0826- ISSN 1110 } \\
& \text { الترقيم الدولي الموحد الإلكتروني 3178-2636 }
\end{aligned}
$$


محمد على محمد (1919)): الوعى التقافى والتتمية من الداخل، مطبعة جامعة الاسكندرية،

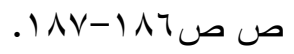

محمود فهى الكردى (r . . r): التراث والتغير الاجتماعى - الكتاب السادس - تأثنير أنماط

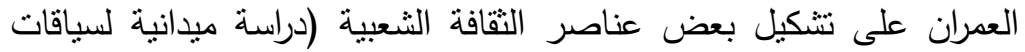

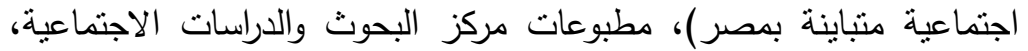

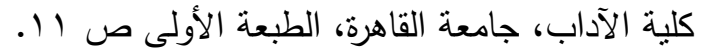

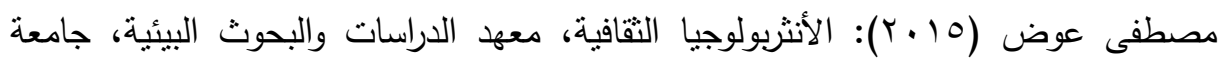

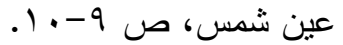

ميشيل تومبسون وآخرون (99VV) (199 نظرية الثقافة، ترجمة، على سيد الصاوى، سلسلة عالم

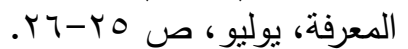

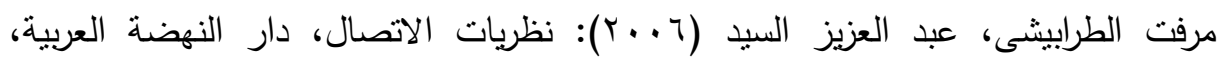

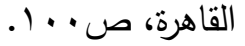

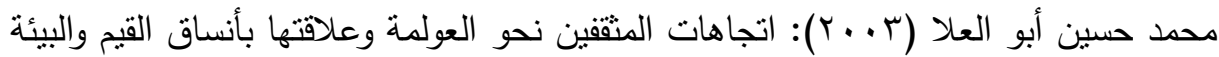

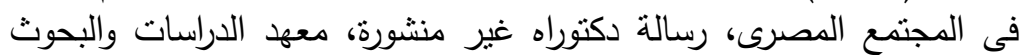

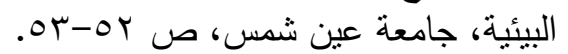

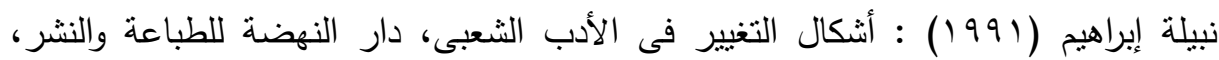

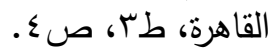

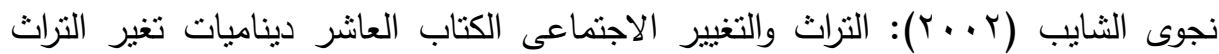

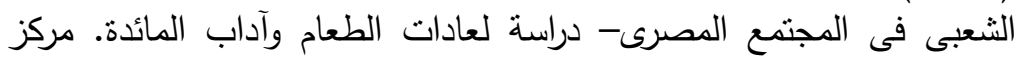

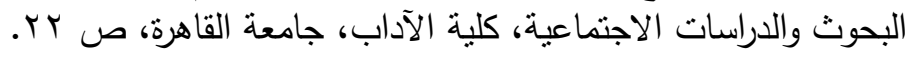

وليد عبد اله الثعبى: مدى تضمين مجالات التتمية المستدامة فى كتاب العلوم للصف الثنانى التئ

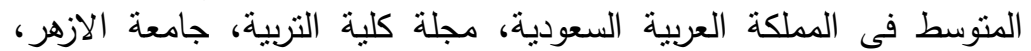

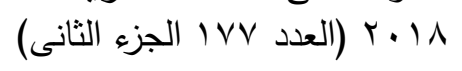

Eunice kerubo Somwel (2020): Folklore as an emergent of residual culture, Kisii University.

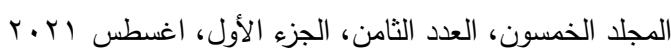

$$
\begin{aligned}
& \text { النزقيم الدولي } \\
& \text { الترقيم الدولي الموحد الإلكتروني 3178-2636 }
\end{aligned}
$$




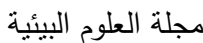

$$
\begin{aligned}
& \text { كلية الدراسات العليا والبحوث البيئية - جامعة عين شمس لئس } \\
& \text { نجلاء حسن الخولي وآخرون }
\end{aligned}
$$

Larilyytimak, Hannasalo, Robert Lepenie Buttner, Jyrimustajaki: Academy of Finland, Strategic Research, Partnership for European Environmental Research, grant, 2020

Saket Bihari: A study of Value Pattern of Secondary School Teachers. Asian Journal of multidisciplinary studies, 2015.

\title{
CULTURAL AND SOCIAL OBSTACLES OF SUSTAINABLE DEVELOPMENT PROGRAMS IN EGYPT A STUDY OF COMMON VALUES AND POPULAR LEGACY ORDER IN EL-DARB EL-AHMR AREA IN CAIRO GOVERNORATE
}

\section{Naglaaa H. El-Kholy ${ }^{(1)}$; Sohair A. El-Attar ${ }^{(2)}$; Nagwa A.El-Shayb ${ }^{(2)}$ Nehal Mohamed Fathy ${ }^{(3)}$}

1) Post graduate student at Faculty of graduate studies and Environmental Research, Ain Shams University 2) Faculty of Arts and Social Science, Ain Shams University 3) Faculty of graduate studies and Environmental Research, Ain Shams University

\begin{abstract}
Current study aims at identifying sustainable development programs presented by national associations of Cairo governorate and identifying methods of common values in the community. Its impact extent on sustainable development programs and identifying cultural and social obstacles of sustainable development in Egypt, and identifying impacts resulting from cultural and social obstacles up to proposed future vision for confronting these obstacles.
\end{abstract}

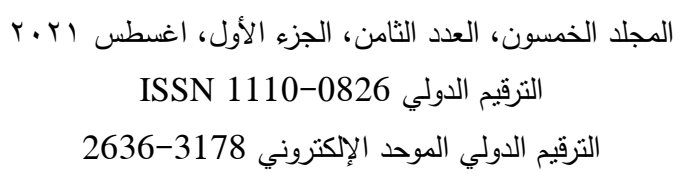




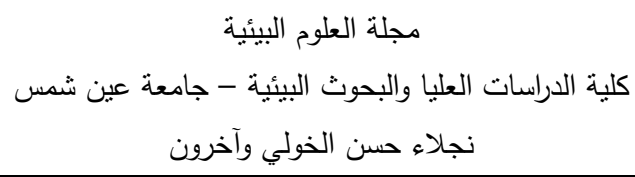

The researchers used the descriptive methodology which is considered a method for studying scientific phenomena or problems through describing scientifically, and also the anthropological methodology that aims at studying human development progress from biological side and cultural side, laws and principles that control this development. Some of quantitative and qualitative methods were made use of, quantitative method of the study is represented in questionnaire form that was designed particularly for collecting data from the field which was applied on (110) of services recipient presented by national associations in Darb El-Ahmr suburb. Qualitative method made use of several research methods headed by the anthropological methodology with its tools starting from observation, meeting, photography and case study of local community and meeting guide of workers in national associations.

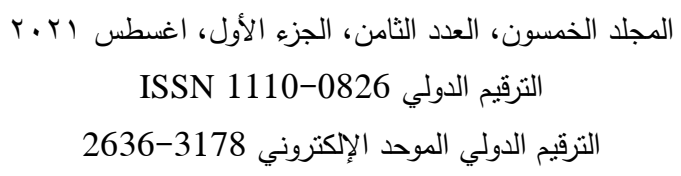

